\title{
NADERE BIJDRAGE TOT DE KENNIS VAN HET ENGGANEESCH,
}

DOoR O. L. HELFRICH.

In het Tijdschrift voor Indische Taal-, Land- en Volkenkunde, Deel XXXIV (pag. 539 en volg.), werd eene door den Heer J. A. J. C. Pieters en mij samengestelde "Proeve van eene MaleischNederlandsch-Engganeesch Woordenlijst» gepubliceerd.

Waar wij bij ons onderzoek aangewezen waren op een Maleier, als tolk, die de Engganeesche taal niet voldoende machtig was, en op een enkelen Engganees, die het Maleisch slechts een weinig verstond en sprak, dit onderzoek bovendien bemoeilijkt werd, omdat de Engganees rad spreekt en menig woord opslikt, was het wel te verwachten, dat het verzameld materiaal op nauwkeurigheid geen aanspraak kon maken. Ik schrijf het dan ook aan die factoren toe, dat de pogingen van de verschillende reizigers om een woordenlijst samen te stellen tot zulke uiteenloopende resultaten hebben geleid. ${ }^{1}$

Die omstandigheid bracht mij er toe, om op de door mij, als Resident van Bengkoelen, naar de eilandengroep Enggano gemaakte inspectiereizen de woordenlijsten te herzien. Ik verifieerde ook de "Proeve" in haar geheel, met behulp van de hoofden van Poelaw Doewa en Karakoewa, die, aangezien zij

1 Men vergelijke de woordenlijsten van: von Rosenberg, van der Straaten \& Severijn en Francis, opgenomen in de bijdrage van Dr. A. C. Oudemans Jzn.: „Engano (bewesten Sumatra), zijne geschiedenis, bewoners en voortbrengselen" in Tijdschrift v. h. Kon. Ned. Aardr. Gen., Afdeeling meer uitgebrẹide artikelen 1889, pag. 126 en volg.; van J. Walland, gepubliceerd in het Tijdschrift voor Ind. T. L. en Volkenkunde, Deel XIV, 1864, pag. 116 en volg., en van E. Modigliani, opgenomen in zijn werk „L'Isola delle Donne. Viaggio ad Eugano", pag. 266 en volg. 
tot de ontwikkeldste Engganeezen worden gerekend en voldoende op de hoogte zijn van het Maleisch, mij voor dien arbeid het meest geschikt voorkwamen.

Aan mijn voornemen, om nader op de taal in te gaan, waardoor ik in staat zoude worden gesteld grammaticale aanteekeningen te maken en meerdere literatuurproducten te verzamelen, die eene deugdelijke basis zouden kunnen vormen voor een, door taalgeleerden, in te stellen wetenschappelijk onderzoek, kon ik evenwel geen gevolg geven. De tijd, dien ik, in verband met mijne drukke werkzaamheden, voor een verblijf op de eilandengroep kon besteden, was daartoe te kort. Jammer genoeg wisten genoemde hoofden mij t. d. niet genoegzaam in te lichten, omdat zij te weinig begrip van grammatica hadden.

De hierbij aangeboden woordenlijst - Engganeesch-Nederlandsch - c. a. heeft men te beschouwen als een omgewerkt, verbeterd en aangevuld exemplaar van de hierboven geciteerde «Proeve».

De raadsels, welke, naar mijne overtuiging, niet oorspronkelijk zijn, doch van de vreemdelingen zijn overgenomen, werden voor een deel $\left(\mathrm{n}^{\text {os }} 1 \mathrm{t} / \mathrm{m} . \mathrm{g}^{6}\right)$ mij medegedeeld door de hiervoren genoemde hoofden, overigens opgeteekend door Fohannes, den Batakschen predikant (pandita) van de "Rheinische Missions Gesellschaft».

De verhalen $\left(n^{o s} 1 \mathrm{t} / \mathrm{m} .7\right)$, de interliniaire Maleische vertaling en de noten zijn mede van zijne hand. Alhoewel ik Fohannes uitdrukkelijk heb verzocht de teksten zoo volledig mogelijk van grammaticale aanteekeningen te voorzien, heeft hij aan mijn verzoek geen gevolg gegeven; blijkbaar was hij daartoe niet in staat.

Hetgeen door hem geleverd is, heb ik ongewijzigd overgenomen.

De verhalen $10 \mathrm{t} / \mathrm{m} .15 \mathrm{zijn}$ in het Maleisch opgeteekend door den toenmaligen Opziener te Enggano, wijlen Radhen Moestapha.

Zoowel van de raadsels als van de verhalen trachtte ik een, zoo getrouw mogelijke, vertaling te geven.

In de "Proeve» werd reeds de aandacht gevestigd op het feit, dat in de taal dialectverschil valt waar te nemen. Het eene dialect behoort thuis in de westelijke landschappen, het andere 
is eigen aan de oostelijke landschappen. Sedert, zooals bekend is, het zielental der inheemsche bevolking schrikbarend is afgenomen, zoodat menig landschap ontvolkt is geworden, moet, althans volgens mededeeling van de hoofden, de afscheiding tusschen de bevolking sinds jaren hebben opgehouden te bestaan en worden, als een gevolg daarvan, de dialecten door elkander gesproken.

De woorden, die in de lijst tusschen haakjes geplaatst zijn, zijn minder in gebruik dan de correspondeerende, welke ze voorafgaan.

In afwijking van hetgeen ik omtrent de spelling en de uitspraak in de "Proeve» bekend stelde, teeken ik aan, dat de $i$ klank in het Engganeesch zuiver is en thans door mij is weergegeven met $i e$. De $\dot{e}$ wordt nu eens gehoord als $e$ in "bed» dan weder als $i$ tusschen de $i$ in "ik» en de zuivere $i$. De opgeslokte $k$ is met $q$ weergegeven, wat mij rationeeler voorkomt, dan die aan te duiden door een $k^{2}$.

Uit het bovenstaande kan blijken, dat aan den geleverden arbeid en aan de kennis van het Engganeesch nog veel ontbreekt. Waar nu overtuigend vaststaat, dat de inheemsche bevolking reeds in de naaste toekomst zal uitsterven, is het, dunkt mij, dringend noodig, om van de taal zoo spoedig mogelijk eene ernstige studie te maken, fouten te verbeteren en leemten aan te vullen. Mogen zij, die door hun werkkring met het volk in aanraking komen en dus in de eerste plaats voor dien arbeid aangewezen zijn, daaraan hunne krachten wijden. 


\section{A. WOORDE N L IJ S T.}

a

a ä ä e ; oudere broeder of zuster.

a äpoe(w)a(q) [a ä fo e(w)a (q)]; neersmijten, neersmakken.

$\mathrm{aba}$; in, te, op.

a baiekahaieq [abaiekahaèq]; negen.

a bakoe(w)a (q) [abako(w)a; abako(w)ě]; geleiden, begeleiden. abaoe(w)aie(j)onie(j)a; last van iemand die heengaat.

aba poe(w) a paoe(w)a; onderzoek, navraag.

$\mathrm{a} b$ è $\mathrm{h} a$ [w a bè h a]; bamboeriet.

$\mathrm{a} b$ è $\mathrm{o}$; braken.

aboeaqä; aandoen, aanhebben, gebruiken, zooals kleederen. aböha; afgedaan, klaar, reeds, voltooid, gereed, ten einde, in orde gekomen uit een verwarden toestand, gedaan hebben met iets, tot rust gekomen.

a dè q [a r è q]; herwaarts, hierheen.

adie [arie]; antwoord, antwoorden, antwoord geven.

adieba [arieba; aliebe]; vijf; adieba hie adoe(w)a

[arieba hie adoe(w)a; aliebé hie adoe(w)ě], zeven. a do; kwaad doen, kwaad stichten.

adoe(w)a [a roe(w)a; a doe(w) é]; twee.

ah adie; roepen, bij den naam roepen, noemen.

ahado; zich oprichten, opstaan, overeind zetten.

ahapieorie; met de hand drukkend over een lichaamsdeel

strijken.

ah a poie; hoop, stapel, opgehoopt.

a harie; verzoek, verzoeken.

aharieohoie; kiezen, uitkiezen, een keuze doen uit.

$\mathrm{a} h$ è $\mathrm{m}$ o i $\mathrm{e}$; besproeien, begieten.

ahiebie; verbranden, in brand steken.

ahiemahona; zie: mahona.

ahopaq; gedachte, nadenken, overdenken.

a ieiejo; groot, dik, zwaar.

aiekoie [aèkoie]; aiekoie(j)a q [a èkoie(j)a q] ; achteruit-

gaan, achterwaarts gaan.

ajoqoie; volgen, achternagaan, gehoorzamen, navolgen.

akieäkiena [akieäkien ̌] ; zes.

Dl. 71 . 
akiedaq [akietaq]; aan iets denken, zich iets herinneren, op zijne hoede zijn, het bewust denken, zich bewust zijn; akiedaqöö, wees op uwe hoede; oe(w)ahobakiekiedaq, $\mathrm{ik}$ herinner het mij weder.

akiehaäq [akèhaäq]; in de zonnehitte gedroogd.

akienaie [akènaie]; kiezen, uitkiezen, eene keuze doen uit. akohaie; maäkohaie, vermeerderen, toenemen.

akoloe [akoroe]; drie.

a ma ; vader.

$\mathrm{a} \mathrm{m}$ a h è $\mathrm{a} q \mathrm{j} a$ [è $\mathrm{ah}$ è $\mathrm{aqj} \mathrm{j}$ ]; deel, aandeel.

amanaie; schoonouders van den man.

a m̌̌naq; van een ander nemen of overnemen, aannemen, nemen, wegnemen, halen.

amĕno [amoeno; moeno; kĕno: koeno]; eten, gaan eten. a mèq; door een band vastmaken, aanbinden, vastbinden, omwinden of vastbinden van een voorwerp om als merk of teeken te dienen.

a moeapo [amoeaf e ]; de gesloten hand.

a moehoe [a moho]: èienoeqoe (q); lang, uitgestrekt van ruimte en tijd; èkariehie, grof, ruw; èkienè [èkiena; èkien $と]$, hoog, hoogte.

an a gaan, weggaan, heengaan.

aniemaie [waniemaie]; de pandanus.

anoekoöq; rooken.

a n ohakèkè; laag, rij voorwerpen op of naast elkander.

a noq ö [anoqoe]; makker, kameraad.

a n o kè ; tegenhouden.

anokie; naar zich toetrekken of halen, voorttrekken.

a n o ö ho; aan beide einden van een stok over den schouderdragen. a n o qè (j)a [a no qè (j) e]; uitgestort, vergoten.

a o e; bez. vnwd. van den eersten persoon.

a oedoe [a oeloe]; voor, vooruit, eerste; (vgl. è oedoe).

a (o)pa [a (o)fa]; vier; a (o)pahiea(o)pa [a (o)fahie$\mathrm{a}(\mathrm{o}) \mathrm{fa}$, acht.

apiea ie; wieden.

a(p)ie(j)aka; kie(a)pie(j)aka, vermoeid, moeilijk van een werk, zwaar van een werk.

a pienie; zich aansluiten, dicht naast elkander plaatsen, doen aansluiten, aan iets dringen.

a poi e; I blazen, wegblazen, blazen van den wind; II 3 à 4 u. n.m. 
aroekoe(w)a [aroekoe(w)o]; aroekoe(w)a [aroekoe(w)o] è (a) ka roba, 9 u. v.m.; (lett.: afsluiten van de ronde opening, waardoor men de woning binnengaat, bij het gaan naar het veld, omstreeks 9 u. v.m.). Zie: è (a) ka roba.

a roeoeieoe(w)a; wrijven van de borst van een borstlijder met pisangbladeren.

awa (b); gaan, weggaan, heengaan.

aw a n a ; teruggaan, terugkeeren.

\section{b}

ba(a)oe(w)a [grwd.: aoe(w)a?] ; hersteld, gezond.

baba I oebaba, groot, zwaar; II (mal.); waarmede een in

Ned. Indië geboren Chinees wordt aangesproken.

badjoe (mal.); kleedingstuk voor het bovenlijf, baadje.

bahabaieba [bahabaiebe]; avond.

bahora; offermaal.

baoe(w)adie [bäadie]; zoeken.

barieboerieboe (mal.); ontelbaar.

bělie(j)oeng (mal.); houweel.

b ěnang (mal.); draad, garen.

biedie [bèdie]; mijnheer, heer.

boe; $\mathrm{I}=$ moe; II voorvoegsel tot vorming van het toestandswoord.

boeboeqie; spuiten van of met water of iets dergelijks.

boedahiejaq; 5 uur in den morgen.

boeodo; I lengte van duur of tijd; II (zelden) oud, in tegenstelling van nieuw.

\section{d}

dadoe(oe); man, echtgenoot.

daiekahadie(j)a [daiekahadie(j) Ł]; de navolgende dag, overmorgen.

dajo; hoofd inz. van een landschap.

daraqie; optillen, opbeuren.

dè t a r (mal.); hoofddoek.

die(j)a [die(j) ě]; bez. vnmwd. voor den derden persoon.

dja (ä)oe(w)a [grwd.: a oe(w)a ?] ; hersteld, gezond.

dodo; in of met de hand vasthouden.

dödöhöka ; erfdeel.

dodokaqäq; standhouden, uithouden. 


\section{è}

è ; afstooten, wegstooten, afwijzen, wegduwen.

èa; I been, gebeente; II schelp.

èa ähaie; de stijlen van eene woning.

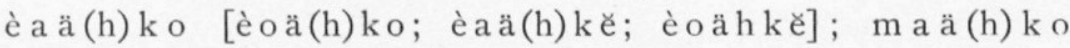

[moä(h)ko: maä(h)k é; moä(h)keّ], zwemmen.

è a (ä) h a o ie; asch, stof.

è a ä koe; zegen, geluk, levensonderhoud, levensmiddelen.

è a ä koh a; handeling, gedrag, handelwijze.

è a ä o e ; ijzer.

è a ä q; oudere broeder of zuster.

è $\mathrm{a} b \mathrm{a}$ ä ; ziekte, pijn, kwelling.

è $\mathrm{a} b \mathrm{a}$ ä $o$; dood.

è $\mathrm{ab}$ a die $(\mathrm{j})$ o [è $\mathrm{ab}$ a rie $(\mathrm{j}) \mathrm{o}$ ]; werktuigen, gereedschappen.

è $\mathrm{a} b \mathrm{a}$ o e kiedaie [è a ba o ekieta i e]; medelijden.

è $\mathrm{a} b \mathrm{a}$ o $\mathrm{e}(\mathrm{w}) \mathrm{a}$; één der typen van eene Engganeesche lans.

è $\mathrm{a} b \mathrm{o}$; zekere pisangsoort.

è a b o e b a ja ; verblijfplaats, woonplaats.

è a d a h o ho e ; hemel, uitspansel.

è a dieho; roosteren van den buik boven een goed onderhouden

houtvuur om een abortus op te wekken.

è $\mathrm{a} \mathrm{d}$ o $\mathrm{e}(\mathrm{w}) \mathrm{a}$; zekere soort van bamboeriet.

è a d o ö (w) ie ; schoonhouden, zuiveren; ook: wieden.

è a è $\mathrm{k} \mathrm{a} \mathrm{b} \mathrm{o} \mathrm{e} \mathrm{;} \mathrm{handeling,} \mathrm{daad.}$

è $\mathrm{ahabaoeda} \mathrm{[è} \mathrm{ahabaoede}]$; zorg, bescherming, hoede;

ook: fokken, kweeken.

è $\mathrm{a} \mathrm{haboe}(\mathrm{w}) \mathrm{a}$; wat ergens voor dient of de sporen draagt van

ergens voor gediend te hebben of, van afkomstig te zijn.

èahaie; zekere papegaaisoort.

èahaienjoqä; oogst, oogsten.

èahaoedohoie; zich het gelaat en het hoofd wasschen.

è $a h$ èdie(j)a [è $\mathrm{a} h \mathrm{èdie}(\mathrm{j})$ ě]; dat wil. zeggen.

è $\mathrm{a} h$ o e poq [è $\mathrm{a} h \mathrm{oefoq}$ ]; ademhaling.

èahopè [èahofè]; het op weg afwachten van iemand om

hem kwaad te doen, in hinderlaag liggen.

è a i e; been, voet, poot.

è a jo [è aj e ]; visch. De door den Engganees genuttigde soorten zijn : è a ka koq; zeevisch;

è a n a ö ;

(die gezouten wordt); 


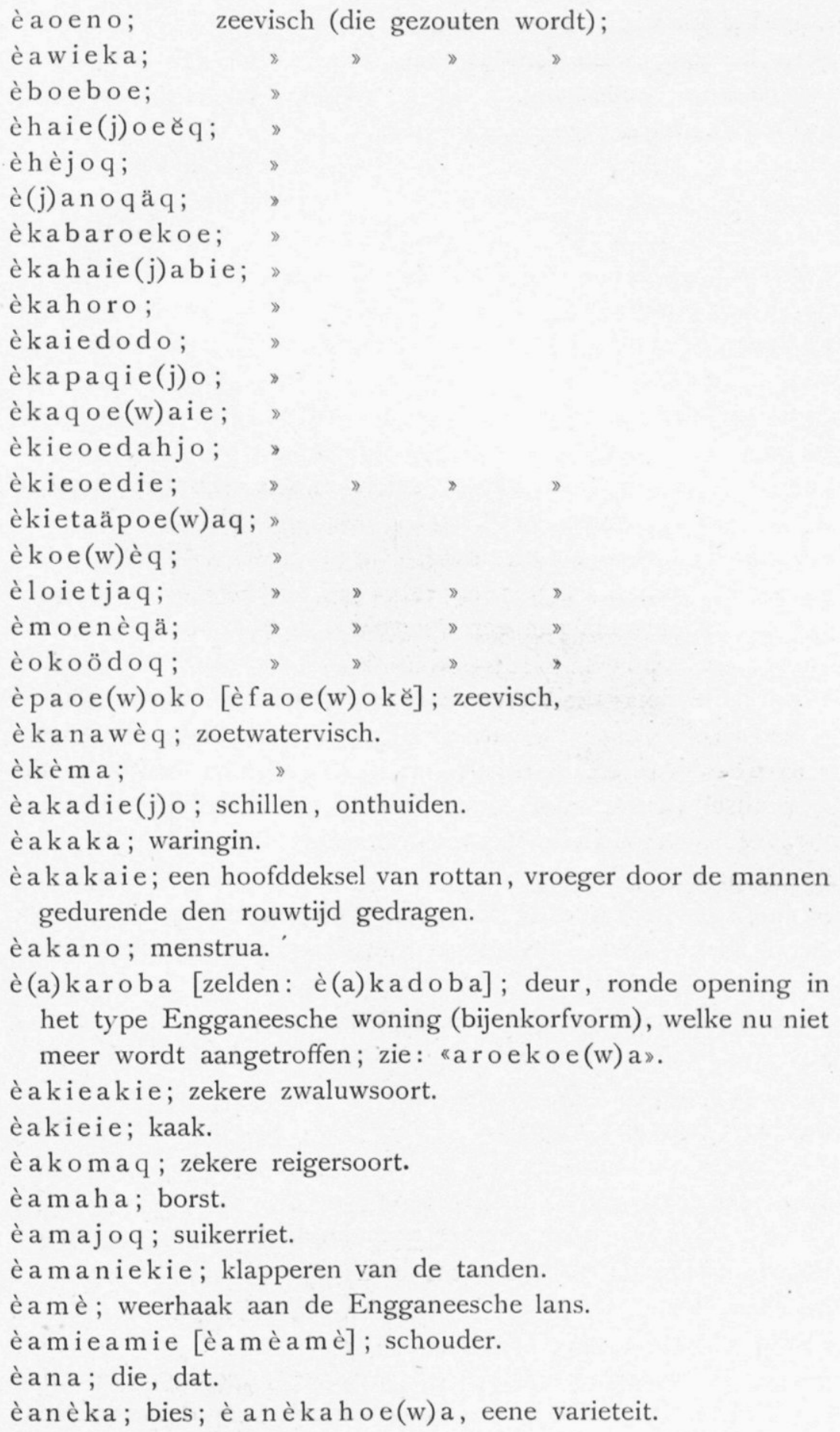


è a nèh a [è a nieh a]; droomen.

è a nokanie; in stukken kappen.

è a n o nö o e ; waterslang.

è a oedahohoe; hemel, uitspansel.

è a o e ka ä; gebit.

è a o h a q; overtreding, misdrijf.

èa okieie; met zijn velen wedijveren om iets meester te worden.

è a $p$ a k o e ; niezen.

è a pa ma [è a fa m a]; zeer veel, eene groote hoeveelheid.

è a pa q [è a fa q]; dik, vet.

è a para [è a fala]; dij.

è a po [è a f e ]; hand.

è a poe [è a foe]; vezel, draad, spier. èa poe èkoe(w)o [èafoe

è koe $(w)$ é]; wortel.

è a poeaka; goedgeefsch, mild.

è a poeq; python.

è a po i e; uitleggers van een vaartuig.

è $\mathrm{a}(\mathrm{q})$; die, dat.

è a r a ; kind, jong van dieren; è a $\mathrm{ra}$ : è $\mathrm{h}$ ö $\mathrm{d} \mathrm{a}$, dochter; è $\mathrm{manie}$

[èmanè], zoon ${ }_{i}$ (oe)èkieho, gebolsterde rijst; (o e)kieadoboe [(oe)kซraroboe], ei; (oe)wabèha, eetbaar uitspruitsel van het bamboeriet; (o e) áie, kleine toon; (o e) a po [a fě], pink; baära [kaära], bevallen, jongen.

è $\mathrm{a}$ a b o e k a ; erfstuk.

è a r a q ko (w) a [è a ra a (q) ko (w) a h]; bloedzweer; melaatschheid. è a roekèr è ; zekere boomsoort met deugdzaam timmerhout.

è a ro $\mathrm{e}(\mathrm{w}) \mathrm{a}$; tellen, rekenen.

è a roja; de vezelige bast van de kokosnoot.

è a ropa [èa lopa]; oksel.

è a $\mathrm{r}$ o qü ; kreng.

è a tja ra [è a ta ra]; spelen.

è a w a q rhizophore.

è ba ; eene liaansoort.

è baba; e. s. v. plant met eetbaren knol.

èbadjiedjo; de wilde groene duif.

è b a h o ; hart.

è b a i ; komen.

è ba ka; oog; è b a ka: (è) o e wè [è o e w è], openingen tusschen de reven, welke een doorgang vormen voor de vaartuigen; 
(oe)kahaoq, zon; (oe)kiedjaie [kietaie], maagholte, maag; (oe)kokoq, tepel; (oe)oemo, zwavelstok.

è b a o e ; zekere pisangsoort.

èbè $\mathrm{lo}(\mathrm{w}) \mathrm{a}$; rivier; ook: de monding van eene rivier zơowel

in zee als in eene andere rivier.

è $\mathrm{b}$ è $\mathrm{o}$; hond.

è b i e h o e; wesp, bij.

è bi e (j) o e ; kleine zwarte torretjes in hout en granen.

è $\mathrm{b} o$; water, regen.

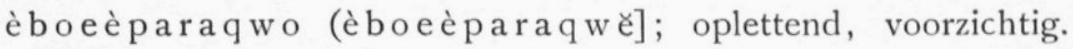
è boe $(w)$ è ; part. pud. masc.

è $b$ oqaboqa [èboqaboq ]; pompoen, kalebas.

èd $\mathrm{aba}$ [èl $\mathrm{aba}$ ]; rechts, rechter, de rechterzijde.

èdaboeho [ètaboeho; ètafoehe]; ziek, ziekte, pijn ;

èdaboeho [ètaboeho; ètafoehé]: èadoho, koorts; è a roiepoko, venerische ziekte; èbaka, oogziekte; è ie-

(j) o eh, buikloop; è k a rè pè (h), steenpuistgezwel; è kie d j a ie [è kieta ie], buikziekte; è o ed o e [è o eloe], hoofdpijn ; è o e k a q, kiespijn; è pa ö, beri-beri.

è $\mathrm{d} \mathrm{ado}$; èd a d o è oed oe [è o eloe], hoofdkussen. èdahajo [èlahajo]; leguaan.

èd $\mathrm{a} h \mathrm{èb}$ o eäo [èlahèboeả o]; getrouwde vrouw.

èdakohaq; hevige storm.

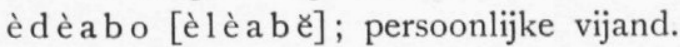

èdieh a o [èdieha oe]; bijten van slangen; schaar van kreeften. è diehie $(\mathrm{j})$ o q; oud kreupelbosch.

è dieho [èrieho]; aardbeving.

èdie (j)a [èdè ja]; etter.

èdie $(\mathrm{j}) \circ[\mathrm{èlie}(\mathrm{j})$ Ł] ook: èdieie $(\mathrm{j}) \circ[\mathrm{èlieie}(\mathrm{j})$ ě]; tong, speeksel. è $\mathrm{die}(\mathrm{j})$ o e (w) a ka; beraadslaging.

è die(j) o ew a o ekèd ja joe; voornemen, plan, bedoeling.

èdiekieho; geroost.

è die k oe roe; lichtstraal.

èdieoboe; èdieoboedie(j)ě, dat is zijn werk, dat hebben

wij aan hem te danken.

èd o b o e [èloboe], goederen, rijkdom; èd oboe [è loboe]

$\mathrm{k}$ an a poe $(\mathrm{w}) \mathrm{a}$, erfgoederen.

èdodie [èdorie]; stroom in eene rivier, bandjir.

èd oehoekie(j)a q [è roehoekie(j) a q); lucifer.

èdohaie [ènohaie]; droog van het jaargetijde. 
èdohoie [èděhoie; èdjěhoie]; hooren, met de ooren vernemen, hooren kunnen; kiedohoie [kieděhoie; kiedjěhoie], getuige, ooggetuige.

èdolèdolè [èlolèlolè]; kleine glaskoralen van allerlei kleur. è d o öa ; vallei, landstreek.

èd o ö ra o e; zand, zandbank.

èdopo [iedopo; è tofo; ietofo]; wat beneden is, benedendeel, onderlaag.

èd o pod o po [è roforofo]; parasiet (plant).

èd o ro [èloro]; met den stroom of den wind wegdrijven.

è è ; part. pud. fem.

è è b a è ; een cassavesoort.

è è da ko [è èla ko]; stamper van steen; zie: è pa h joe.

è èè no ; zekere boomsoort, waarvan de bast, na geklopt te zijn,

voor het vervaardigen van kleedingstukken wordt gebezigd. è è h è ; hoest, hoesten.

è̀ ho ; hoe, wat.

è è $\mathrm{h}$ ö a k koud, koude.

è è (j) a q ; koraalrif, koraalbank.

è è $\mathrm{k} \mathrm{a} \mathrm{j} \mathrm{jie}(\mathrm{j}) \mathrm{a}$; zijn gevoeg doen.

è è ko ; urine, urineeren.

è èlo; weenen, tranen storten.

è è $\mathrm{m}$ a $\mathrm{h}$ a ; dakspar.

è èn $\mathrm{a}$; schubben van dieren en planten.

è è $\mathrm{n}$ è $\mathrm{h}$; dadap (boomsoort).

è ènono; è ènono: o e po [oefé], de taaie bladscheede van

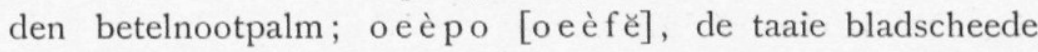
van den niboengpalm.

è èo die [è èolie]; vel, dop, schil; è è odie o eko ewó [èèolieoekoew 厄], schors.

è è o q; ergens wegleggen of weggelegd hebben om het te be-

waren, bewaren, plaatsen, neerzetten.

è è $\mathrm{p}$ è ; links, de linkerzijde.

è è po [è èf $\mathrm{f}$ ]; niboeng, gekloofde niboenglat voor bevloering. èh $a b a \operatorname{rie}(j) a$ [è $h a b a r i e(j)$ e]; eene rustbank van hout.

è $\mathrm{h}$ a d o $(\mathrm{q})$; worm.

è hahadiediekie : draai, kronkel.

è h a i e poe [è h a i efoe]; omkappen van hoogstammig geboomte.

è hamo; vlucht van vogels; kiehahamo, vliegen.

è h a moa; ijlen, hardop droomen. 
è ha noe (w) a ; hals.

è h a o [è ha è]; stookplaats.

è ha robèa o; woelen, krauwelen in het haar.

è ha roeq; hebben, bezitten.

è h è a po [è h è $\mathrm{a} f \mathrm{o}$ ]; groot zwaard.

è h è bo e ; minnelied.

è h è i e (j)o [è h è i e (j) ě]; broeder of zuster.

èhèja; trap (eertijds een schuin in den grond geplaatsten boomstam, waarin treden zijn gekapt).

è h è koe (q) [è h a è koe (q)]; m a h è ko e (q) [ $\mathrm{m}$ a h a è koe (q), zitten, gezeten zijn, gaan zitten; è hè ko e (q)wa [è h è ko e (q) $w$ Ł̌]; roeibank.

è hè la; vol, gevuld; kè o hèla, ledig, waar niet in is.

è h è o e (w) a ; vrucht.

è h è o e (w) è ; korrel.

è hè $(q) i e(j)$ o e j jongere broeder of zuster.

è h èr ie (j) a ; kust, strand.

è h i e (j)o; wat, welk.

èhoa; asch.

è hö a die [èhöarie]; bezem; mahöadie [mahöarie], vegen. è hoanie; vliegende hond.

è ho (w) a po [èho $(w)$ a fé]; palm van de hand.

è hoboe; zekere boomsoort, waarvan de bast, na geklopt te zijn, gebezigd wordt voor het vervaardigen van kleedingstukken; zie: è̀̀̀ è no.

¿èh ö d a ; vrouwelijk.

è h o e k o e ; luis, vloo.

è ho e $(w) a ; s l a k$.

è ho ka ; snijden, afsnijden, slachten.

è hokaie; achterste van menschen (ook van dieren); anus. è h o k a (q); kakkerlak.

è ho k o e; overgebleven stomp, afgehouwen stuk, afgesneden stuk, snijden, afsnijden.

è ho po; gat, kuil.

è h o q ä; inktvisch.

èhora; dans en zang bij het "kalèakoebaba»feest.

è howaie; zool van den voet.

è i e; deze, dit.

èieboe; vermetel, moedig, stout; ook: norsch, wild, grimmig, geen tegenspraak kunnen verdragen, slecht, kwaad, iemand kwaad dnen. Dl. 71 . 
èiedjie [è̀̀jie; èietjie]; geluid, stem, het zeggen, wat door iemand gezegd wordt, iemands woorden, gezegde, raad, raadpleging, oordeel; a i edjie [a èdji e], antwoord, antwoorden, antwoord geven.

è i e h a ; wat, welke,

è ieie; spijker, nagel, pen, speld, naald; è ie i e o edoe [èieieoeloe], een haarspeld van bamboe. è i e (j) a o e ; zekere vogelsoort (béo).

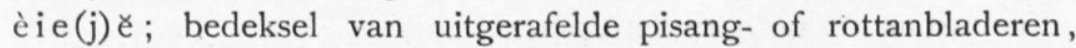
eertijds door de vrouwen gedurende den rouwtijd gedragen.

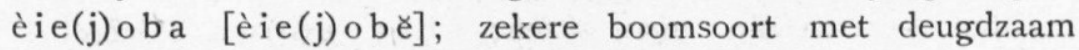
timmerhout.

è $\mathrm{ie}(\mathrm{j})$ o e dopo; dier, beest in tegenstelling van andere wezens. è i $\mathrm{e}(\mathrm{j})$ o ö bo ö i e ; groot werpnet in gebruik bij de zeevischvangst. è ie noeq.o (q); lang, lengte; zie: "amoehoe».

èienoeqoeie; eene reeds brandende toorts.

èiepo [èief é]; rook.

èietjo; zekere rottansoort.

è (j) a da ma ie; fijn snijden, tot iets snijden.

è(j)aha; plaats, verblijfplaats; è(j)ahakoqie, leven, ziel ; è (j) a h a o e obie, dammarkaars, lamp.

è (j) a h è a q a q ; wetten, aanzetten.

è (j) a ko qä ; litteeken.

è (j) a k o ro $(w)$ a ; bijleggen van een geschil.

è(j)aniemaie $=$ aniemaie.

è (j) a q è to ka ; in het verderf gestort, verdelgd.

è (j) a raq [ie(j)a raq]; dat niet, bij verbieden; è (j)araq ie(j)araq] noeha, handel niet aldus, niet op die wijze.

è (j) obie; vuur, aangestoken licht.

๕(j)o po ko; beitel.

è $\mathrm{k} a$ ä; mond van menschen en dieren.

è kaba iedoq; eene papajasoort.

è kabaieka; baden.

è ka ba kè ; lijk.

è k a ba kèk a ; makker, kameraad.

èkaboeäjo; klein werpnet in gebruik bij de zeevischvangst.

è $\mathrm{k}$ a d a b o e qä; vleermuis.

è ka daha(q) [è karaha (q)]; lichaam.

èkadieodie [èkarieorie]; musch.

èkadie opè [èka die ofè]; de ontvangkamer van het gezin. 
è k a d o do (q); zekere boomsoort met deugdzaam timmerhout. è k à̀n ; (het mal. "kain») doek, geweven stof inz. van katoen, kleedingstuk tot bedekking van het lichaam van den middel tot de voeten.

è $\mathrm{k} \mathrm{a} \mathrm{h} \mathrm{a} \mathrm{;} \mathrm{sehorpioen.}$

è k a haba; net om vogels te strikken.

è $k$ a h a è pie; kreeft.

(è) $k a h$ à q [(è) $k a$ è q]; één.

è kahanoa; zekere boomsoort met deugdzaam timmerhout. è k a h ä ; achterzijde, rug.

è $\mathrm{k}$ a h a o e ; buiten eene omheinde plaats.

è ka ha oekoe; ananas.

è kahaoq; dag.

è k a hi $(\mathrm{j})$ o e ; alang-alang.

è k a h i en o (a); witte mier.

è $\mathrm{k}$ a h o e (w) è qo ; hagedis.

è k a i e ; drek, uitwerpselen.

è k a i e no (h); kopje, bordje, schoteltje.

è ka ie (oe)dahoe(hoe) [è ka ie (oe) la hoe(hoe); èkaèdaho;

èka èlaho]; de lucht; ook: wolk, regenwolk.

èkajoqpèdjie [èkajoqfèdjie]; een van de typen van een Engganeesche lans.

è kakorèie (j)o [è kakorèie(j) e] ; weerkaatsing van het licht, schitteren.

è k a k o rè (j)o ; vijl.

è k a mie (j) o e ; zekere pisangsoort.

è ka naja; op, niet meer voorhanden.

è $\mathrm{k} \mathrm{a} \mathrm{n} \mathrm{jo} \mathrm{q} \mathrm{;} \mathrm{kopje.}$

è kan oa ; damp, wasem.

è k a no aie; de maan.

è ka noe o e noe; vogelklauw.

è k (a) o eq pa noe [è k (a) o eqfa noe]; zekere vogel (doendoen). èk a o e (w)a (gwrd.: a o e (w) a ?) [è k a o e (w)é]; fraai, mooi om te zien.

è ka pahoeka; zekere boomsoort, welks hout uitsluitend voor brandhout gebezigd wordt.

è $\mathrm{k}$ a pè lo; een papegaaisoort.

è k a poe h; oud, in allerlei beteekenissen.

è k a (q) ka (q); mensch, menschdom, lieden.

è ka rao e (w) a hè ; geweven kleeding in het algemeen, stof. 
è k a r è pè [èkělèpè ; èkal èpè]; zweer, puist.

è karara; zeer, tot vorming van den overtreffenden trap.

èkarieha [èkalieh ě]; oor, oorsieraad, destijds bestaande in opgerolde pisangbladeren, ringen van een kleine soort kokosnoot of van hoorn vervaardigd; èkarieha [èkalieh é]: oe $(w)$ a po [oe(w)af e ], armband (gew. van glaskoralen of akar bahar); oe(w)a ie, voetring.

è $\mathrm{k}$ è è ; citroen, pompelmoes.

è $\mathrm{kè} \mathrm{è} \mathrm{pa}$ [è $\mathrm{kè} \mathrm{è} \mathrm{fa}$, vogel; $\mathrm{k}$ i e èè $\mathrm{pa}$ [ki è̀ è $\mathrm{fa}$ ], vliegen, stuiven, opstuiven van stof enz.

è kè h(è); korte breede bijl.

è $\mathrm{k}$ è $\mathrm{h}$ è $\mathrm{o} \mathrm{do}$; doorn.

è kè kong; een instrumentje, dat men tusschen de tanden neemt en daarmede het geluid "ginggong" maakt.

è $\mathrm{k}$ è $\mathrm{m} \mathrm{a}$; milt.

è $\mathrm{k}$ è $\mathrm{o}$ ä $\mathrm{h}$; braken.

è $\mathrm{k}$ è $\mathrm{o} \mathrm{q}$; rottan.

è $\mathrm{k}$ è $\mathrm{pon}$ ie ; muts.

è ki e a kie ; vloeiingen.

èkieakoqä; stok met twee of drie ijzeren punten, waarmede de visschen, die uit het net trachten te ontkomen, worden gestoken.

èkiea po [èkieafé]; sprinkhaan.

è kieda pè (j)a [èkiet a pè (j)a]; spaander, splinter.

èkiediebèie(j)oq [èkietiebèie(j)oq]; een der typen van eene Engganeesche lans.

èkiedjaie [èkietaie; èkiedaie]; buik, ingewanden.

è k i e d jè ; zekere boomsoort met deugdzaam timmerhout (měrbau). èkiedjiekiedjie; Spaansche peper.

è ki è̀ è $\mathrm{o}$; bochtig van een weg.

ékiehie; eene rottansoort.

è ki eh ie (j) o edo; zekere boomsoort met deugdzaam timmerhout. è ki eho; mier.

è kiehö a ; dorst.

è kiehoedo; I nerf van het kokosblad; II eene niet brandende

toorts. De toortsen worden van klapperbladeren vervaardigd. èkiehohè (j)a [èkèhèö(j)a]; reden, omdat; èieha kieho$\mathrm{hè}(\mathrm{j}) \mathrm{a} \operatorname{die}(\mathrm{j}) \mathrm{a}$ : wat is daarvan de reden.

è kieie; kin.

è kieie $(j) o[$ [èkieie $(j)$ e]; dauw. 
è k i e i e (j) a h a q; schild.

è kie (j)a ö ; muskiet.

è kie(j) oe ; wind.

è kie(j) o eqie; e. s. v. kleine parkiet.

èkieka; halssnoer van koraal.

è kiekie; kam.

è kiekohaq; eene cassavesoort.

è ki e mo; I schelp; II het voor den Engganees onbekende land(?). èkienono; cardamom, langkoewas (een specerijachtige wortel). èkieodoha; de hooge kant van iets.

è ki et j a ho ; duizendpoot.

è k i e t jo h; haai.

è kiet o hè ; hoofddeksel van boomschors.

è k o a noe ; rat, muis.

è kö a q; op zij af, zijweg.

èkodie(j)o [èkorie(j)o]; verhaal, vertelling.

èkodaäjo [èkoedaäjo]; verhaal, vertelsel.

èkoeaka; stam, boom.

è k o ed o d o ; rijk.

èk o edodoka; één persoon, lichaam.

è koeha [èkoha]; stam, boom.

è koehie $(\mathrm{j}) \mathrm{o}$; raadsel.

èkoeka ; struik, stengel; èkoeka(oe)waie, scheenbeen.

è koe ma (q) a o e; mug.

è koena; tak, boomtak.

è koeöedo; baadje.

èkoepado [èkoepadě]; omheinen van een bouwland, van een tuin.

èkoe (w)abo; een der typen van een Engganeesche lans.

è koe (w)iekoe(w)ie; e. s. v. vogel.

è ko e (w)o [è koe e (w) é]; tak, boomtak, hout.

è ko h è a q ; zich met bladeren, inz. van den pandanus, beschutten

tegen den regen; regenscherm.

è koh (o ie); heuvel, berg.

è ko hoq; vuil, handvuil, huidsmeer; èkohoqioe(j)obie, asch.

è kojoq; varken, zwijn.

è kokoq; de borsten van eene vrouw.

è konienie ; clitoris; kokonienie, kittelen.

è konjoq [èkoöq]; honger, hongerig zijn.

è k o q; gevorkte tak. 
è k o qä; vullen, bevatten, inhouden.

è koqa (j) odie(j)a ; overgebleven stam zonder kruin of takken, een tronk.

è ko (q) h a jo ; geneeskundige (doekoen).

è ko (ö) q ko (ö)q ; nipapalm.

èkoq (n)ja oe; de bagoeboom.

èko qoeie; voorhoofd.

è ko ropie [ook: èkoropie(j)oèoeloe]; hersenen, merg.

è $\mathrm{ko}(\mathrm{w}) \mathrm{a}$; pad, gang.

è $\mathrm{ko}(\mathrm{w})$ èq [èkoèèq] I geest, zoowel goede als kwade; èko-

(w)èq [èkoèèq]: oeèbo, geest, die de bronnen bewoont; è $\mathrm{o}(\mathrm{w}) \mathrm{è}$, geest, die de zee bewoont; ie (j)akapieta [ie(j)akafieta], geest, die de rivieren bewoont; kaoedara, geest, die de doesoen bewoont; oehoeqkoe(w)o [oehoeqkoe(w)e], geest, die de bosschen bewoont; oewokie, geest, die de zeekust bewoont; II naam aan een inlander — vreemdeling inz. aan een Maleier toegekend.

èla ä poe(w)a [èla ä foe(w)a]; krokodil.

èlahä [èlahaoe]; èlahä [èlahaoe]: èhöda, nicht ; è $\mathrm{m}$ a n ie [è $\mathrm{m}$ à $\mathrm{n}$ è], neef.

è la ohoe; donder.

èlè; klimmen zooals bijv. in een kokospalm.

è $\mathrm{lè} \mathrm{a} q ;$ snot.

èlo a ba ; weerlicht, bliksem.

èloha [èloho]; boot (sampan), vaartuig.

è $\mathrm{m}$ a ho $\mathrm{kakie}$; e. s. v. vogel.

è $\mathrm{m}$ a $\mathrm{n}$ i $\mathrm{e}$ [è $\mathrm{m}$ a n è]; mannelijk.

è $\mathrm{m}$ è $\mathrm{n} a \mathrm{hoa}$ oè $\mathrm{m}$ è $\mathrm{n}$ a ho $\mathrm{e}(\mathrm{w}) \mathrm{a}]$; planken vloer.

è mèno; vocht uit de kokosnoot, palmwijn.

è $\mathrm{m}$ è $\mathrm{o}$ [è $\mathrm{m}$ è $\mathrm{a}$ ö] ; kat.

èmienoemienoe; de arenpalm.

è $\mathrm{moa} \mathrm{moq}$; zekere boomsoort met deugdzaam timmerhout.

è $\mathrm{moe} o \mathrm{e} \mathrm{h}$; aarden pot om in te koken.

è $\mathrm{mo} \mathrm{mo} \mathrm{q}$; zekere boomsoort met deugdzaam timmerhout.

èmoö i e (j)a [èmoöie(j)ę]; wrong.

èn a è (n a); moeder van menschen en dieren; ènaè $(n a)$ : oe $(w)$ I a po [oe(w)af̌e], duim; oe(w)aie, groote toon.

èn a n a uitleggers van een boot (sampan).

èn a n o o e $(w)$ è; baar, golf, deining.

èn a pa [è n a $\mathrm{p} \check{c}]$; vlak terrein. 
ènapienapie [ènafienafie]; moesang.

èn a pienie [ènafienie]; nauw, benepen, bekneld, geklemd. è r è ; met de beenen wijd uit elkander bij het loopen, als kinderen. èn è hè i e; zekere boomsoort met deugdzaam timmerhout.

èn èa n èa ; lokaas.

è nè $\mathrm{k} \mathrm{a}$; hoofddoek.

èn iè̀n $\mathrm{ie}(\mathrm{j}) \mathrm{a}$; snauwen, afsnauwen.

èn $\mathrm{i}(\mathrm{j}) \mathrm{o}$; naam.

ènienie; tand.

èn oä [èn o e ]; zwaar, drukkend.

èn o eq o eq; diep, diepte.

èn ohaie; droog van het jaargetijde.

è nomonomo; de middel.

è no ö hoq; mansvracht.

è o $\mathrm{a} b \mathrm{a}$; damp, wasem.

è o bo ; varken, zwijn.

èodie [èorie]; waarde, prijs; apieha èodiedie (j)a [èorie-

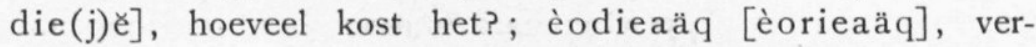

koopen; bodieaäq [borieaäq], zich bezig houden met verkoopen; kahohodieaäq [kahohorilaäq], handel drijven. è o dieök a [èoriöka], schuld, geldschuld.

è o d ji e ; roeiriem.

è o d o ; scherp, scherpsnijdend.

è odöda; verplaatsen van eene nederzetting.

è o d oe [è o roe]; de měngkoedoe.

èo dohèie [èorohèie]: de balken die dienen om daarop zolder of vloer te leggén.

è o e ba [è o e b $\mathrm{b}$ ]; huis, woning; è oe ba [è o e bě]: è ka èn,

kist, koffer; èkieadoboe [èkiearoboe], kippenhok; èkojoq [èobo], varkenshok; ètèbè, woning van dikke, dicht aaneensluitende, loodrecht in den grond geplante stammen inz. van den niboeng; kèèèpa [kèèèf $\mathrm{e}]$, nest, vogelkooi. è o e d a ; levend, frisch, versch.

è o e di e ; bast.

è oedoe [è oeloe]; hoofd in alle beteekenissen; è oedoe

[è o e lo e] b è $1 \mathrm{o}(\mathrm{w}) \mathrm{a}$, oorsprong eener rivier. è o è $\mathrm{h}$ è $(\mathrm{j}) \mathrm{a}$; mat van de pandanus vervaardigd.

è o e hoe ; uil (vogel).

è o eko; geldboete.

è o e k o e; veest. 
è o e k o ea ie; lange stok, duwboom op vaartuigen.

è oekoediepo [èoekoeriepo]; de lippen.

è o e koeie; naald.

è o e k o eqoe; vertikale omwandingsplanken.

è o ekoe (w)aie; voorhoofdsband, bestaande uit een boomblad

nu en dan versierd met de vederen van een papegaaisoort.

è o e ma ; eene groene wilde duif.

è o e miehie; een in het wild groeiende notenmuscaatboom.

è o e mo [è o e m e] ; vlieg; zie : "èbaka».

è o en è kè ; mand van gevlochten rottan.

è (o e) n o e kie (j)o; zeegarnaal.

è o eoe; steel om iets mee aan te vatten, steel van bloemen,

vruchten enz.; èoeoe(w)apo [èoeoe(w)afë]; benedenarm. è o e o e n o e ; landschildpad.

è o e po [è o ef $\mathrm{e}]$; de betelnootpalm.

è o e poeie $(j)$ o [èoepoeie(j)e] ; bloem, bloesem.

è o e poeqoe $(w)$ o [èoepoeqoe $(w) e$ ] ; huiduitslag, muggebeet. è o e poe e (w) a [èo ef oe (w)a]; hard loopen, hard wegloopen.

è $\mathrm{o} \mathrm{e}(\mathrm{w}) \mathrm{a}$; een rottansoort.

è oe $(w)$ a i e [èoe(w)aè ; èè (w) aie ; èè (w), à̀]; ; voet.

è $\mathrm{o}(\mathrm{w}) \mathrm{aka}$; uitspreken van een woord, van een naam.

è o e (w) a po [èoe(w)af̌ ; è̀̀ (w)apo; èèwaf é]; bovenarm.

è o $\mathrm{e}(\mathrm{w}) \mathrm{o} \mathrm{h} \mathrm{o}$; slapen, dutten.

è (o)hora; è (o) hor a o e kè è pa [kèè fa]; fluiten van vogels. è okaha; achterhoofd.

èokahao [èokaha é]; nek.

è o k a q ; lachen.

è okie (j)o ; eene manggasoort.

è o ko; wig, keg.

è o ko a; droogplaats voor klappers en visch.

è o ko (ऍ) ; model, proef, maat.

è o koeh; èokoehèoedoe [èokoehèoeloe]; hoofdkussen.

è o k o h è ; glad, effen, schaaf.

è o ko mè ; het over iets smals heengaan.

è okopie [èokofie]; dekkleed van boomschors.

è okoq; touw.

è o $\mathrm{mo}(\mathrm{kie})$; bewaken, waken, wakker zijn, de wacht houden, wachten, toeven.

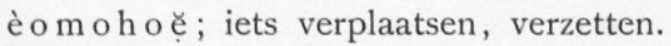

è o mon a; hoeveelheid, aantal. 
è o mo qö; zweet.

è o nokĕ; e. s. v. beitel.

è ononie; een rottansoort.

è o ö ba q; stok, staak.

è o ö bo; ravijn.

èo öboq; kruipen zooals kleine kinderen.

è o ö kie; zaag.

è o pa ; kalebas.

è o poe [è ofoe]; een grassoort.

è nq o e; keel.

è o q o q; hard, sterk, krachtig.

è o q o qi e; luidkeels lachen.

è o ra i e; rottanmand.

è $\mathrm{pa}$; kies.

è $\mathrm{pa}(\mathrm{a}) \mathrm{h}$ o n a ; huwen, huwelijk. (Zie: hona(o)).

è $\mathrm{p}$ a ä no ; vriend, bevriend zijn met.

è $\mathrm{p}$ a ä o ; vast, gedegen.

è pa bo ri e ki e ; oorlog, gevecht.

è $\mathrm{p}$ a d o edoe; met zijn velen tegelijk.

è $\mathrm{p}$ a è $\mathrm{ka}$; riviergarnaal.

è $\mathrm{p}$ a èlo è $\mathrm{p}$ a èlo i e ; beweenen van een afgestorven bloedverwant.

è $\mathrm{pa}$ èn oqjaqü; koevoet van hout.

è $\mathrm{p} a$ è $\mathrm{p} a$ [è $\mathrm{f} \mathrm{a}$ è $\mathrm{f} \mathrm{a}$ ]; vleugel, vlerk.

è p a h i ed o a ; schelden, uitschelden.

è pahjoe; een ovalen bak, waarin de vruchten van de bagoe, na geschild te zijn, kaladie of onrijpe pisang met een stamper van steen - è è dako [è̀̀ lako] — worden fijn gestampt. è $\mathrm{p}$ a ho ; breed, breedte.

è pahoäq [è pahoahoäq]; verboden zaak, zich onthouden van iets, verboden als schadelijk, als onbetamelijk, verboden en ongeoorloofd bij een sterfgeval.

è $\mathrm{p}$ a h o e (w) a ; toornig, vertoornd, boos, vergramd.

è pa i en ö ; bedrog, list, streek.

è paka; een in het wild voorkomende kaneelboom.

è $\mathrm{paka} \mathrm{maie;} \mathrm{mes.}$

è pa kèlie ; zoenoffer tot bijlegging van een familiegeschil. è $\mathrm{p}$ a k o e hè [è f a k o e hè] ; mast, paal, stijl.

è $\mathrm{p}$ a k o e i e : tripang.

è $\mathrm{pako}(\mathrm{w}) \mathrm{a}$ [è $\mathrm{pak}(\mathrm{a})(\mathrm{w})$ ě ] uit elkander, van elkander gescheiden. 
è palè [èfalè ; èparè]; zoowel nageboorte als het bloedstremsel, dat na de geboorte volgt.

è pan a n ä ; geschrift, schrijven.

è $\mathrm{p}$ a noe $[$ è fa noe $]$; neus.

è pa no eka; slaperig.

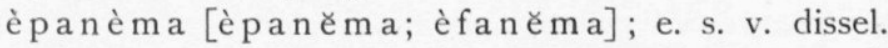

è $\mathrm{pa}$ ö ; achterzijde, rug.

è $\mathrm{p}$ a o $\mathrm{pa}$ [è $\mathrm{fa}$ of $\mathrm{e}]$; vlinder, kapel.

è $p$ a oqöqaie [èfaoqöqaie]; schreeuwen van menschen en dieren.

è pè; in, te, op.

è $\mathrm{p}$ èa [èfè a]; rand, boord, zoom, oever.

è pèa (i e) ha ; kokosmelk.

è pèd jie ; kapmes; èpèdjiekèèqbara, Palembangsch kapmes.

è pè do $\mathrm{o}(\mathrm{w}) \mathrm{a}(\mathrm{o})$ [èpèdoe $(\mathrm{w}) \mathrm{a}(\mathrm{o})$; è fèl $\mathrm{o}(\mathrm{w}) \mathrm{a}(\mathrm{o})]$; ster.

è $\mathrm{p}$ è $\mathrm{h}$ è [è fè hè] ; oorsprong, begin.

è pè k o e (w) a q ; lever.

è pè k o e q w a q; maag, krop.

è pèn a ö; keuvelen, praten.

è pèr $\mathrm{r}$ a o e di e [è pěrh a o e di e]; bovenarm. (V.g.l.: èoe(w)apo).

è pèrie (j)oq; (mal.) aarden of metalen pot om in te koken (pěrijoek).

è pi e a k o (w) è q; zekere pisangsoort.

è pi ea o e (w) a po [èpiea oe(w)afě]; tusschenhandsbeenderen.

è piedjaja; arm, armoedig.

è piedjoe; zekere boomsoort met deugdzaam timmerhout.

è piedjoeapo [èpiedjoeafě]; eěne liaansoort.

è $\mathrm{pieh} \mathrm{o}$; èpiehooe(è)oe $(\mathrm{w}) \mathrm{è} \mathrm{;} \mathrm{zeeschuim.}$

èpie $(j) a$ [èfie $(j)$ e] ; bouwland, tuin.

è pie $(j) \circ p i e(j) \circ[$ èfie $(j) \circ f i e(j) e]$; kuit.

è pi e ko; manggistam.

è pienie; schaar, knipschaar.

èpieniepie [èfieniefie]; boomlooze vlakte.

è pi e pie [èfiefie]; horizontale omwandingsplanken.

è $\mathrm{poäq}$; eene rottansoort.

è poeä [epoeaoe]; klapperdop om er uit te drinken.

è po ed a ri e; doorn.

è poedoe [èpoeroe]; dooden van levende wezens.

è poeha; kruin in alle beteekenissen.

è po e i e h o e; eene menngkoedoesoort. 
è po eko [è foekě]; navel, navelstreng.

è poen o e; blad.

è p o e oe ; knie.

è poe e (oe)qoe; geleding; è poe(oe)qoe: oe(w)a po [oe(w)afe]], pols; oe(w)aie, enkel.

è poe roedoe (ie) [è poe roe roe (ie)]; I haarvederen; ook: schaamharen; è po e roedoe(ie) [è poeroeroe(ie)]: èoedoe [èoeloe], hoofdhaar; oebaka, oogharen; II dakbedekking van bladeren; è poeroedoe(ie) [è poeroeroe(ie)]: a niemaie [waniemaie], dakbedekking van pandanusbladeren; èko (ö) qko(ö) q, dakbedekking van nipabladeren; oeietjo [o ekèoq], bedeksel van rottanbladeren, eertijds door de vrouwen om den middel gedragen gedurende den rouwtijd. è $\mathrm{po}(\mathrm{a} \mathrm{h}) \mathrm{h}$ a [è po e $(\mathrm{ah}) \mathrm{h} \mathrm{a}]$; teeken, merkteeken, uiterlijk voorkomen, zichtbare gedaante.

è $\mathrm{poh}[\mathrm{è} \mathrm{o}(\mathrm{h})]$; kokospalm. è $\mathrm{pohkèa} \mathrm{q;} \mathrm{plant} \mathrm{met} \mathrm{eetbaren} \mathrm{knol} \mathrm{(kěladie).}$

è poko [è $\mathrm{foko}$; in, binnen in.

è pon an a è (è ponanamie); jonge man, jongmensch. è po (ö) $\mathrm{kah}$ a [è poe (oe) $\mathrm{kaha}$ ]; spin, spinneweb. è poökie [è popoökie]; schieten, schietgeweer. è $\mathrm{poq}$ a ; asch.

è $\mathrm{po}(\mathrm{q})$ i en a mo; jong meisje, maagd. è poro; zekere boomsoort met deugdzaam timmerhout. (è q) è h o e n è ; testikel. è tè bè [ie tè bè]; boven, bovenste oppervlakte, hoog. èwakiepöro [èwakieföro]; benauwd, beklemd, aamborstig.

\section{g}

garam; (mal.), zout.

goeroe; (mal.), onderwijzer.

h

ha; het mal. achtervoegsel "lah». habakao; eene lengtemaat gelijkstaande met twaalf vadem. haboejaq; samenverbonden, zooals een rist uien, bladeren aan een tak, vruchten aan een steel.

haie; wat, wie, wie ook, hoe; haiejaha, waar; abahaie$\mathrm{jaha}$, waar ter plaatse; kahaiejaha, waarheen. $\mathrm{h}$ alè ; eerst, eertijds. 
$\mathrm{h}$ a mè hèn ie ; insnijden.

haoe; bijten van menschen $\mathrm{cn}$ dieren.

hèdapiehie [hèlapiehie]; betasten, aanvatten.

hèie $(\mathrm{j}) \mathrm{o}$; achterste van dieren.

hie; met, door middel van; ons: plus.

hiebaie; de achterkant, de keerzijde, omgekeerd, terug, naar huis terug, weder terugkeeren.

hieie(j)oie(j)o; nu en dan, somtijds.

hie(j)onie; krabben, graven met de handen.

hienoea; dikwijls, vaak.

h o; reeds, ook gebruikt tot vorming van den volkomen verleden tijd. hoäkoqaq; tot aan toe, er toe komen, bereikt worden.

hobaäoeie(j)aka; verzadigd, voldaan.

hobaäoe(w)a [hobaä oe(w) e] ; zuiver, helder, zindelijk.

hobahaba; bedaard, tot rust gekomen, opgehouden (van den regen). hobè̀è ö [o bèèa ě], makker, kameraad.

hoboek; tevreden, welbehagelijk.

$\mathrm{hödahöda;} \mathrm{verbruikt,} \mathrm{reeds,} \mathrm{ten} \mathrm{einde.}$

hodiedieka; hersteld, weer beter.

hodiekie [horiekie]; boor, gedraaid, gewonden.

hoè an a ; behoorlijk, passend, betamelijk.

hoeka; haar.

hoeko(q)ä [hokoä]; eene heilige plaats, waar de meeste

geesten verblijven.

hoe oe noeka; soekoe (stam).

hoie; van den grond oprapen, plukken.

$\mathrm{höka;}$ slachten van een dier.

homaie; krabben, graven met de handen.

homanieka; ochtendstond.

hona (o); getrouwde man, echtgenoot.

honoaha; worden, geworden zijn, geboren worden, ontstaan, groeien.

hopaie [hofaie]; schoot.

hopanao; overeenkomst, verbintenis, afspraak, belofte.

\section{ie}

ie ; bij, op, naar.

iedjie; slaan, kloppen met iets.

ieho; in, binnen; ieho akoloe poq, binnen drie dagen; iehoie-

(j) a n a, daarbinnen. 
i e(j)a äo ; kracht, krachtig, sterk.

ie(j)abie; geschild, gepeld, gevild.

ie(j)aha(ie) = haie(j)aha; zie haie.

ie(j)ahaoefoeaq; gezegd van iemand die tot een andere "soekoe» dan de zijne behoort.

ie(j)o; hiel; met de hielen trappen.

ie(j)oho; dan, bij den vergelijkenden trap.

ie(j) okie; ondiep, niet diep.

ie(j)omoö; N. N.

ie(j)onie [ienoie]; in of door iets heen steken of graven of peuteren, delven, opdelven,

ie(j)onie(j)a; door, uit kracht van.

ieka; wij.

iekahä ; daarbuiten.

iekahoboe(w)ara; met opzet, willens, opzettelijk.

iekara; benevens, met.

iekoedoha (iekoedaha); niet goed kunnen zien.

iekoeko; achterzijde, rug.

ienaou(w)a [ienaou(w) Ł]; omhoog, omhoog gaan, klimmen. ienoenoeq [manoenoeq]; zoeken.

ie noqie; een gat graven, maken.

ietaqoe(w)a; opdat, ten einde.

i e tè q; die, dat.

ietjo [iedjo]; drinken.

ietjoehaq; argwaan, verdenking, vermoeden.

\section{k}

$\mathrm{ka}$; wij (met insluiting van den aangesproken persoon).

$\mathrm{ka} a ̈$; dood, einde, gaan liggen van den wind.

$\mathrm{ka} a ̈$ ämie; onbewoond, eenzaam, verlaten.

kaä(ä) o e(w)a [kaä(ä)ou (w) ๕]; dik, vet, zwaarlijvig, vet van

menschen en dieren.

kaädahoaie [kaärahěaie]; bitter van smaak.

kaädodie; opgelost, verteerd.

ka ädo(j)a [kaädoie(j) é; kaäroie(j)ě]; nog meer, nog steeds. kaähoeöie; oude vrouw.

$\mathrm{ka} a ̈ j o q ;$ een der typen van eene Engganeesche lans.

$\mathrm{ka}$ (ä) kèo; bevrucht, zwanger, drachtig.

k a äk èho; gierig, vasthoudend, karig, vrekkig. 
kaäkie: droog, uitgedroogd.

$\mathrm{ka}$ äkiè̀; meer, over, te veel, overschot.

kaäkiekie(j) e; het gevoel in de tanden, wanneer ze met iets

zuurs in aanraking komen.

ka äkien a fah; blauw, donkerblauw.

$\mathrm{kaäkienè} \mathrm{[kaäkènè;} \mathrm{kakanie(q)];} \mathrm{gew.} \mathrm{verbonden} \mathrm{met:}$

"è b a ka»; blind.

kaäkieniepa [kaäkienief $е$ ]; groen.

kaäkoeka(h); kracht, krachtig, sterk.

kaäkoho; zwart, donkerkleurig.

$\mathrm{ka} a ̈ \mathrm{mie}$; snijden van rottan.

$\mathrm{k}$ a ä o e; uitgebluscht van vuur of licht.

$\mathrm{kaäpa} \mathrm{oe;} \mathrm{lucht,} \mathrm{reuk,} \mathrm{geur} \mathrm{[onaangenaam].}$

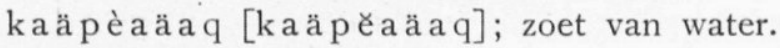

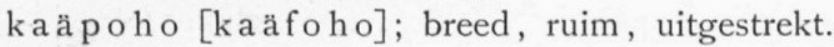

kababahaq; ebbe, vallen van het water.

kabaèlo; de papaja.

kabahoa [kaběho]; op weg ergens aangaan of bij iemand vertoeven.

kabahöjaäq; snugger, schrander, verstandig, slim.

kabakoä; geankerd zijn.

kabatjoä; onrecht, onrechtmatige behandeling, kwaad doen,

kwaad berokkenen van geesten.

kaběa; het uitkomen van een ei.

$\mathrm{k} a$ bè hoq; stelen, heimelijk wegnemen.

kabiekaka; vredeteeken.

k a bi e kè bi e; gevlekt.

kaboe(w)aboe(w)a [kaboe(w) ěboe(w)e] ; rond, ovaal.

kaboekoe; weduwe.

k a dèadèa [kalèalèa]; stinkend, verrot, bedorven.

kadèda; gemakkelijk.

kadèdè; vol, verzadigd.

kadiehie [kariehie]; zuiveren van gras en onkruid.

kadiekopo [kadiekofë]; plat geslagen bamboe voor omwanding en vloer.

kadoboedoboe; afval, vuil.

kadodohodie; hitte, heet door vuur van water.

$\mathrm{k}$ adoèhoeda; het moet nu uit zijn.

kadoqö; beplanten van een veld, planten, begraven, in de aarde leggen. 
ka ènaha; vêrvolgens, onmiddelijk, daarop.

ka ènoe; staan.

kaèöèo; kruipen van eene slang.

kah; kom, komaan; (uitruep tot aansporing, opwekking).

kaha; loopen, gaan, op weg zijn, op weg gaan.

kahabaja; mededoen.

kahabaoeba; eenig, alleen.

kahabarieq; werk, dat men heeft uit te voeren, arbeid; werken, arbeiden.

kahabieta; vlaktemaat (bidang); hulptelwoord bij het opnoemen van bouwlanden.

kahaè; ondeugend, kwaaddoende, stout.

kahapa [kahafa]; overwal.

kahaho [kahoho]; bevreesd, bang, bang maken, vrees, vreezen. kahaie; iemand uitnoodigen bijv. om met hem mede te gaan. kahaiekoenaq; gissen, meenen, denken, vermoeden.

kahaienoeapè [kahaienoeafé]; nog, nog steeds, juist, zelfs, overig.

kahaja; wenschen, willen, verlangen.

kahakakie; snel van den stroom.

kahakouda [kahakoude]; verdeelen, deelen.

kahao; kahao: èmanie [èmanè] oom; èhöda, tante.

kahaoeq; bot, stomp.

kahaoka [kahaoke]; gebroken, doorgebroken, afgebroken.

kahapaq [kahafaq]; over iets nadenken, overdenken, bedenken. kahapie [kahafie]; begeeren, verlangen, belust zijn op iets, willen ook van zaken; genoegen, vreugde, verheugd, tevreden zijn met iets, op iemand gesteld zijn; liefhebben, liefde.

kahapoeoeie(j)a; paar, koppel.

kahapoeqoeie; opborrelen van het water uit een wel. kaharao; één vaam.

kahèd ohèdo [èhèlo]; onrein, onreinheid.

kahèè ; plagen, sarren, tergen.

kahè(j)oq; krom, gebogen, bocht in eene rivier.

kahiekanie; fijn, dun.

kahienoaq; witte mier.

kahiepa [kahief๕e]; steken, zeer doen.

kahoeie(j)oeroe(w)a; bovenloop eener rivier, eene rivier opvaren. kahoepohoepö̈ [kahoefěhoefö̈]; opgezet van den buik, opgezwollen van de wangen. 
kahopo; stoel, spruit, stengel van planten.

kahö(w)a; ophouden, vertoeven, uitscheiden.

kaie; met de armen aanvatten, vastgrijpen, pakken.

kaie(j)à̀; omlaag, naar beneden gaan.

kaie(j)anono [kaie(j)enono]; stil zijn, zich stil houden, zwij-

gen, stil staan.

kaie(j)ojo(q); in de lengte uitgestrekt.

kaiekoko; rood.

kaienono(q); smaak van iets, gevoel, geur.

kajajaä; ruim, wijd, open.

kajo; recht, zonder bochten, oprecht.

kajoöie; op elkander volgen, gehoorzamen, volgen, meedoen. kakanaka; pěkakanaka, uitgespannen zooals een touw. kakanakoe(w)a; glans, luister.

kakanèha; een half, de helft.

kakaraie; drijven, voor zich uit drijven, wegjagen, nazetten, ver-

volgen, op iets afgaan, iemand of iets achternazetten, najagen. kakarie(j)o; woning, die de gedaante had van een op circa

10 hooge palen geplaatsten, bijenkorf (zulke woningen worden

niet meer gebouwd).

kakèkaka; strak, stijf aangehaald.

kakèlèha; stoel, spruit, stengel van planten.

kakiedahaie(j)o; geel.

kakiedjoa; sterk verlangen naar iemand of iets.

kakiedohè; voorbij, gepasseerd, voorbijgaan, passeeren.

kakiekiedohè; recht toe, recht aan.

kakiekie(j)oe; verborgen, verscholen.

kakiepakiepa; spat, spikkel, vlekje.

kakoehè; dalen van hemellichamen.

kakoenjè; curcuma (het mal. «koenjit»?); geel.

kakoeöqö; laag, nederig.

kaköoe; geknakt, afgebroken, breken, afbreken, in stukken breken.

kakoro(w)a; iets aan de geesten afsmeeken.

kalèaq; feest; kalèaq(oe)baba, het groote feest.

kamanaä; overkomen van ongelukken.

kamoepie [kamoefie]; niet willen, niet verlangen.

kamoenieno; iets wat pas uitstoelt, wat pas opkomt van aanplantingen.

kamoho; het mal.: "maka».

kamonie; zoet, lief, innemend. 
kanakienie; een van de typen van eene Engganeesche lans.

kan a poe; oud mannetje; oud vrouwtje.

kanapoeäq; druipen, lekken, een druppel, een lek.

ka napoen oe; schimmel, beschimmeld.

kanèko [manèko]; er door kunnen, ruim genoeg om iets

door te laten, te laten doorgaan.

ka nè̀n è; dun, fijn, teer.

k a nèn o nèno; glad, glibberig.

k a n è o n è $\mathrm{o}$; opgelost, verteerd.

$\mathrm{k}$ a n è $\mathrm{p}$ oe [ $\mathrm{k}$ a n èfoe]; kort, niet lang.

kanè (q)a; beschaamd, verlegen.

kaniehie; kaniehie(j)aniehie(j)a; vlug in bewegingen.

kaniekie; licht, helder, duidelijk, doorschijnend.

kaniekoa(ä)q; lek, lekken inz. van eene woning.

kanie(nie)kie; hevig kloppen van het hart.

kanieniepo(w)a; niet fijn genoeg, niet dun genoeg.

kanoeaie; ongeluk, onheil.

kanoeanoea; dik, niet vloeibaar.

kanoeqkoe(w)aie; schaduw, schaduwbeeld.

kanoöho(w)aq; iets (bijv. regenwater) opvangen door er wat onder te houden.

kao(e); opgesloten, ingesloten.

kaoeäq; dat, waar men op drijft.

kaoedada [kaoedara]; doesoen.

kaoedahjo [kaoerahje]; wit, blank, zuiver.

kaoedaoe(w)arah; naakt.

ka oedèqää; het ophouden, omhooghouden om iets op te vangen.

kaoenie(j)a; plein van eene doesoen.

kaoepè(q) [kaoefè(q)]; nog niet, nog nooit.

kaoe(w)a [kaoe(w)e]; mooi, fraai, goed; aangenaam voor de zintuigen inz. lekker om te eten V.g.l.: è ka o e (w)a.

ka oe $(w)$ èoe $(w)$ è; zout, brak.

ka oe(w)ie; zwart.

kaokie; ebbe, vallen van het water.

kaoöbo [kääbo]; raak zijn, geraakt.

kaoöèiedjie [kaoöèèdjie]; onbeschoft, ruw, ongemanierd.

kaoöo; hard, stijf, taai, onbuigzaam.

kapaie; geschild, gepeld, gevild.

Dl. 71. 
kapal [kafal]; (mal.), groot schip, vaartuig; kapal [kafàl] api [afi]; (mal); stoomschip.

kapaoe; de overzijde van eene rivier, oversteken.

kapěraperaba [kafĕrafĕraba]; zeldzaam, schaarsch, wijd van elkander.

kapieho; misleiding, dwaling, verkeerd zijn, mis, verdwaald, dwalen.

kapoe; midden, middelmatig.

kapoeho; = èdaboeho.

kapoeka [kafoekě]; onbegaanbaar.

kapoeq(oe)a; instorten van woningen, van rotsen, ineenzakken inz. aan den kant.

kapoko; lekslaan van een vaartuig.

kapopo [kafofo]; kероро, kefofo]; betrokken van de lucht, donker, duister van den nacht, de zon, de maan.

kaqakaie; roest.

kaqamano; aangenaam van geur, reuk, lucht.

kaqapopoero; ongelijk hebben.

kaqienèaoe; achterdocht, achterdochtig.

karaoe; sluiten, dekken, toemaken.

karieporiepo [kaliepoliepo]; troebel.

karoe(oe)(w)a; broek.

karohaja [karohaje]; bedekt, achter iets verborgen.

karorie(j)é; landschap, district.

kěbahè; komen.

kělamboe; (mal.), gordijn.

k mie(j)oe: tritonschelp als omroepershoorn gebezigd.

kěnaja; op, niet meer voorhanden; v.g.l.: è kanaja.

kěwalie; (mal.), ijzeren pan.

kè; maar, doch, evenwel, echter.

kèè; voorbijgaan, doorgaan zonder er op te letten.

kèhèkoq; gebroken van voorwerpen, zooals beenderen, stokken, armen, beenen.

kèhèla; mager, smal, tenger.

kèho; oorlel.

kèhodojo [kèhorojo]; iets, waarmede men iets uitpeutert, iets

uithaalt.

kèhowa; te vergeefs.

kèkèqie; stompen, vuistslagen geven.

kèkoe(w)èq; niet tot stand komen, niet ontstaan, niet gebeuren. 
kèlokèlo; modder, slib, slik.

kèma; tellen, rekenen.

kèmonaq; houwen, hakken, doorhakken.

kèo; niet bestaan, niet aanwezig zijn.

kie; voorvoegsel tot vorming van het passief.

kiea; een flap, een klap. V.g.l.: kieqja.

kieadoboe [(è)kiadoboe; (è)kiaroboe]; kip, hoen.

kieakie; bodem, vaste wal.

kieakoena; stok met twee of drie ijzeren punten, waarmede de visschen, die uit het net trachten te ontsnappen, worden gestoken. kieakoeq; een van de typen van een Engganeesche lans.

kieapaä; vast tegen iets aanzitten, aankleven, vast blijven zitten. kiebaka; onrijp, jong.

kiebèdieka [kiebèrieka]; verwelkt, verdord.

kieboeho; jong.

kiebohèie; wild, niet tam of mak.

kiedahoho [kietahoho]; een stuk, een afgesneden stuk.

kiedahaq [kietahaq]; het met iets fijns of puntigs in of door iets steken, iets puntigs om mede te steken.

kiedahoaq; rouwtijd.

kiedajaq; hellend, scheef.

kiedaoedaoe; plat van een bord.

kiedara; alle, geheel en al.

kiedèdè(j)aq [kierèdèjaq; kèdèdè(j)aq; kèrèdè $(j) a q] ;$ koper.

kiedie; doorboren; kiedie (è)kèho, doorboren van de oorlel. kiediediehoq; ruim, wijd, open.

kiediedieka; vlijtig, naarstig.

kiedieopè; woning.

kiediepoe; wegwerpen; kiediepoe (èq)èhoenè, castreeren.

kiedjaieie(j)aq [kiedaieie(j)aq]; kreupel, mank.

kiedjie; het pikken van vogels.

kiedjiedjieö; verdwaald, dwalen.

kiedjiekiedjie; gescheurd.

kiedjoro; erfgenaam.

kiedo [kieto]; als, evenals, zooals.

kiedobieka [kierobieka]; sluikharig.

kiedodo; macht, volmacht, kracht, machtig, gezaghebbend,

in staat tot iets; kiedodo iedjie [èdjie], stamvader.

kiedoropoq; welig, frisch van planten.

kiè̀ (ja); afweren, afwenden. 
kiè̀̀ lo; krom, gebogen, verkromd.

kieèn o e; erectie van den penis.

kiehiebie(j)a; zout, brak.

kiehiema(na), een weinig; kiehiema(na) èodie [èorie],

goedkoop, laag in prijs.

kiehieoba; uitgebluscht van vuur van licht.

kiehoè (j)a; deugdzaamheid, waarde, nut.

kiehohoda(q); ongehuwd.

kieiedoka; gewond, wond.

kieie $(\mathrm{j})$ o èdaha [kieie $(\mathrm{j})$ o èr $\mathrm{ah} \mathrm{a}$ ]; verschrikt, ontsteld, onthutst.

kieiepo [kieiefé]; nevel, mist.

kieietjo; zekere pisangsoort.

kie(j)a; hij, zij.

kie(j)abaq [kè (j)abaq]; er niet zijn. kie(j)abaq [kè(j)abaq]

iekè o, vertrouwen, hopen.

kie(j)ahariedjoe; eene getah leverende boomsoort (balam). kie(j)aie; waarmede een in China geboren Chinees wordt aangesproken.

kie(j)oenano [kie(j)oenan ‘]; woelen in den slaap, onrustig slapen.

ki e (j)oèdoha [è roha]; verschrikt, ontsteld.

kie(j)oha [kè(j)oha]; niet goed, niet in den haak, niet gaaf, versleten.

kie(j)oho; licht, daglicht.

kie(j)okko; e.s.v. boom (baroe), van welks bast touw wordt vervaardigd.

kie(j)opèka; ingevallen van de oogen of de wangen, vervallen van het gelaat.

kie(j) oqoqaq; naar beneden springen.

kiekaäboe; vergeten zijn, vergeten.

kiekaäna; kaal van het hoofd.

kiekabiedja; ergens aan of in vastzitten; verhinderd, belet. kiekahaoeba; tegenaanloopen, stooten.

kiekaoba; verbaasd, verstomd, verbaasd staan te kijken.

kiekaraq(a); stuk, in stukken zijn, in stukken breken, gebarsten, gespleten, gekloofd.

kiek ěnèn a q; met stukken er af, uitvallen van tanden en kiezen. kiekěroa; tam, mak.

kiekè èla; berst in vruchten. 
kiekè (è)o e (w)a [kiekè (è)o (w)a]; weggezonken bijv. in zand enz.; verzonken, vergaan, te gronde gaan.

kiekè or a (q); verdwenen, verloren, weggeraakt.

kiekèpoqä; het ploffen van iets zwaars in het water.

kiekè poqoe (w)a [ki ekèfoqoe(w)ě]; inzakken van de voeten. kiekèqie; stampen, aanstampen.

kiekie(j)a [kiekie(j)ě]; zijn, wezen, bestaan, leven, gebeuren, er is.

kiekie(j)a qkie(j)a q; tegenstribbelen, zich verzetten.

kiekie(j) a ra; alleen overblijven, achterblijven, blijven liggen van werk.

kiekie(j)o; gew. verbonden met: «èbaka», knipoogen. kiekienie; fijn hakken zooals fricadel.

kiekoekoe(q)ö [kiekoekoe(q)ě]; zorg, moeite, last. kiekoho; blazen van slangen en katten.

kiekohodaq; vloed, hoog water.

kiekoko; zitten van vogels of als een vogel op boomtakken. kiekokonie(j)a; kittelen. V.g.l.: kokonienie (zie: èkonienie). kiekononaq; slap, loshangend, niet gespannen.

kiek o o e (w)a; een hoofddeksel vervaardigd van rottan, pandanus of nipahblad, den vorm hebbende van eene phrygische muts.

kiekoöka; nauw, eng, smal; ook: ondoordringbaar.

kiekoro(w)a; bedaard, tot rust gekomen van wind, van eene onstuimige zee; kalm, bedaard van water.

kiela oeloe; zekere boomsoort met eetbare vruchten (kětapang). ki e m èm è è baha o eq; haat, nijd.

kiemoenie; komkommer.

kiemoenie(j)o; leugenachtig, leugen, onwaarheid, onwaar. kiemomojo; schaduw.

kienanaja; afbreken, slechten; bederven, geschonden, vernield.

kienanapa [kienanafě]; vlak, effen.

kienienaqèkaq; uitstooten van de oogtanden, eene mutilatie welke niet meer plaats heeft.

kienienèqa; glimlachen.

kienjono; hoe zit dat nu, hoe komt dat.

kieno; duiken, indompelen, indoopen.

kienoäo; drijven, aan de oppervlakte van het water komen. kienoeoeka; verhemelte. 
kienono; waarvoor, waartoe, waarom. kienono: è(j)a [è (j) è], op welke wijze; è (j) a d i e (j) a [è (j) a die (j) ̌], hoe dat nu; è (j)a è, hoe dit nu.

kienöna(w)aie; tred, stap.

kienoqè(j)a [kienoqè(j) e]; uitgestort, vergoten. kiodèa [kieor èa]; dutten.

kie e enèkaq; gekerfd, schaardig, met afgebrokkelden rand. kieojo; langzaam, traag, talmend, laat, te laat; zorgeloos,

onachtzaam, ergens niet aan denken:

kieokahaie [kieokahè]; luidkeels lachen.

kieonieka [kieonieke]]; verdord van bloemen en planten. kieoö; dicht van het loof der boomen, van bloesems.

ki eo ö aq ; sprong, het springen.

kieoöie; ontginnen van den grond door zuivering van onkruid. kieoöno; onderdoen, verliezen.

kieoönopa; ontworteld, uitgerukt. kiepa(a)oeq [kiefa(a)oeq]; tien. kiepadie; kiepadieoeiedjie [èdjie]; krakeel, harrewarrerij. kiepahoe(w)a [kiefahoe(w)a]; woordentwist, getier, leven,

rumoer.

kiepaka; bleek van gelaatskleur. kiepakaowaq; een bekende.

kiepakiedja; vermengd, dooreen, ondereengemengd.

kiepa; kiepakiepa pahoeoenaq [kiefakiefa fahoeoe-

n a q]; schemering, schemerdonker.

kiepakobaq; het bij iets komen, ontmoeten, tegenkomen. kiepakoeka; stief, in stiefvader enz. kiepakoekoeoedie; rimpel, plooi.

kiepakoko [kiepakoekoe]; de juiste richting, de juiste plaats.

kiepakokokie [kiepakoekoekie]; bedorven, geschonden, vernield.

kiepamiemiehieka; verbrijzeld tengevolge van een val.

kiepamo [kiefamé]; vol, gevuld, volkomen.

kiepamoemoeoeie; kroesharig.

kiepapakoe [kiefafakoe]; slapen van den voet.

kiepaqaq [kiefaqaq]; opeengedrongen, dicht op elkander gedrongen.

ki e pa ra è b a hao (q) [ki e pa r a è ba hoe (q)]; gek, zinneloos, zinsverbijstering. 
kieparahpie; dicht, goed sluitend.

kieparahopie; dom.

kieparoa; vlam.

kieperraiedie(j)oq [kieparaèdie(j)oq; kiefalaiedie(j)oq]; stom.

kiepěhaie [kief ̌̌haie; kiepoehaie; kiefoehaie]; weten, weten te doen, het kunnen, in staat zijn, knap, bedreven, verstandig.

kiepèh èboeöbo (v.g.l.: oöbo); kruipen van een kind. kiepèh od o [ki efěh o d e ]; doof, hardhoorig.

ki epè oraq [kiefè or a q]; los, ontglipt, uit de hand geschoten, ontsnapt.

kiepiepie [kiefiefie]; gezegd van eene rivier, die niet te diep is om te worden doorwaad.

kiepoäka; tam, mak.

kiepoäraq [kiepoe(w)araq; [ki e poe(w) a ra q]; gebarsten, gespleten, gekloofd.

kiepoedieka [kiepoerieka]; ontspruiten, groeien, ontstaan. kiepoefoe [kiefoefoe]; opborrelen van kokend water.

kiepoeoeda [kiefoeoede] ; neerkomen, vallen.

kiepoe(w)a [kiefoe(w)a; kiepö(w)a; kiefö(w)a]; zien, opnemen, bekijken, aanzien, afzien.

kiepohajĕ; aannemen, zich bereid verklaren.

kiepokana [kiefokana]; openspringen, uit elkander springen. kiepokiepo [kiefokiefo]; het glaga riet.

kiepoö; dicht van den regen.

kiepopoä [kief ofoä]; verbrijzeld, vergruisd.

kiepoqöaq; open, uit elkander.

kieqja [kieqję]; met de vlakke hand om de ooren slaan.

koahajo [koq(a)hajo]; geneeskundige. V.g.l. : èko(q)hajo. koahie(j)a [koahie(j) e]; avond, nacht; koahie(j)a [koahie (j) e] kapoe [kafoe]; middernacht.

köda; levend, frisch, versch.

kodo; het in eens doorslikken, opslikken.

koe; voorhoofd.

koeano [koeana]; wanneer, als, toen.

koedaqä; vertellen, zeggen.

koedè; van, afkomstig van; koedè: iejaha, waar van daan, van waar; iepoko, van binnen; ietopo [ietofo], van buiten. 
koedèja; gene.

koedodoka (ook: èkoedodoka) [koedoroka]; lichaam,

20 taka's (zie: taka).

koedoe [koeroe]; uiterste punt, uiteinde, kaap.

koehaie; hulp, bijstand; hulp verleenen, helpen.

koehèdie [kohèdie; koehèlie; kohèlie]; ruilen, wisselen, verruilen, verwisselen, veranderen van vorm.

koehèdie $(\mathrm{j})$ aq [koehè lie $(\mathrm{j}) \mathrm{aq}$; ; veranderen van den wind. koehiemaq; jeukte.

koeie; koeie karieha [kalieh 飞]; gaten in de ooren boren

om er versierselen in te dragen. V.g.l.: kiedie.

koeiehie; richting; doel.

koeienaq [koeienanaq; koienaq; koenènaq, koena-

n a q]; juist, juist zijn, echt, waar, werkelijk, inderdaad.

koejaq; voortschuiven, wegschuiven, toeschuiven.

koekaq; lende.

koekoebaka; zekere pisangsoort.

koemènoè̀ [koemènoeẻ]; zekere boomsoort met goed deugdzaam timmerhout.

koemoe; fijntjes knijpen met vinger en duim.

koenajo; drie steenen voor treeft, om het kooksel er op te zetten.

koepèie; in de plaats van iets anders komen, vervangen, ver-

goeden, vergoeding.

koeripo [koelipo]; de lippen.

koe $(w) a$; ingaan, binnengaan.

koe(w) adie; omlaag zien, bukken.

ko hè a q; hut.

kohopaie [kohofaie]; op den schoot houden.

kohopie(j)oe [kohofie(j) ‘] (ook: kopopoiejě(?); kleinkind. kokieha; verminderen, slinken.

kokoäaq; persen, drukken bij hardlijvigheid.

kokő̌; gissen, meenen, denken, vermoeden, berekenen.

kokoie (j) à̀ ; lui, traag.

kokona [kokon $飞]$; naar buiten, naar buiten gaan, te voorschijn komen, uitgaan, uitkomen, voor den dag komen. (ko)koro(w)a; met elkander verzoend, vrede als einde van twist of oorlog.

kolè; het aan beide einden van een stok over de schouders dragen van lasten, wegdragen. 
komojaqä; los, vrij, ontkomen.

komokomo; modder, slib, slik.

konèka; verwelkt, verdord.

ko nohaq(?); 12 u. 's middags.

kononaq; afvieren, vieren van touw.

kö̈ma; rustbank, slaapbank.

ko pèn è; wurm, rups.

kopèq; eene soort van ebbenhout.

kopo [kofo]; begraven, graf.

kopodieqie [koforieqie]; zuigen, opzuigen, inzuigen.

koqoq; I het in iets gezakt zijn. II = kadoqö(?).

koqoqma; ronde plaats destijds aangetroffen onder de woning

(bijenkorfvorm), dienende tot bewaarplaats van mandjes en ander huisraad.

koqowie; hellen, overhellen.

koraq; kennis geven, mededeelen.

\section{m}

ma (ä)h on a (grwd.: hona); huwen.

maha m è; zekere pisangsoort.

mahona (q) [mohona (q); ahiemahona(q)]; vreemd; een ander, anders, onderscheiden, onderscheid, geenszins.

ma o nè; feest bij sterfgevallen.

měnokie [monokie]; wasschen, reinigen.

miemie; ver, verte; miemiena; zeer ver.

miena; mienaoe(w)a po [mienaoe(w)afe $]$, vinger; mienaoe(w)aie [mienaoe(w)à̀]; toon.

mienjaq; (mal.), olie.

moe; bez. vnmwd. van den tweeden persoon.

mohoie; zekere bamboesoort.

mohomohoiena [mohomohoienoe]; alle, allerlei.

mokie (omokie); wachten, toeven, verbeiden.

moko; veel, hoeveelheid; moko èodie [èorie] die(j)a

[die(j) ě], duur, hoog in prijs.

mo ö; die, dat.

\section{n}

naäie(j)aha; bij zich hebben, dragen, mede of wegdragen, meenemen, wegbrengen. 
$\mathrm{n}$ a äpoe(w) aka(q) [na äfoe(w) a ka(q)]; voorouders. $n$ à̀h a pè [naähapè; naäpè; naèh afè; noähafè; naäfè]; aanstonds, eenmaal, in het vervolg, wachten, iets afwachten, ergens op wachten, een oogenblik.

$\mathrm{nahaja}$; gezegd van iemand die een zijner bloedverwanten door den dood heeft verloren.

naienaie; schoonouders van de vrouw. Zie: amanaie. $\mathrm{n}$ a o emana; morgen, den volgenden morgen.

naponaq [nafonaq]; ijdel, tevergeefs, kosteloos.

$\mathrm{n}$ a qä; aannemen, ontvangen.

na qie (j)aie; medebrengen.

$n$ è è $n$ i $[\mathrm{n}$ è èn è]; zoo even, onlangs.

$\mathrm{n}$ èn è $\mathrm{k} a$; verscheurd, aan stukken gescheurd.

nie(j)a $[n i e(j) e]=\operatorname{die}(j) a[d i e(j) e]$.

nie(j)oöhieniea [nie(j)oöhienie e]; inham, baai.

noaha; kienoaha (kanoaha); zooals dat.

noahaq; kunnen, mogen, krijgen.

noèa ä q; schuins, omlaag, zooals eene flesch terwijl er uit geschonken wordt.

noenohoie [nonohoie]; vragen, navraag doen.

noha; toelaten, laten begaan, laat het geschieden of zijn.

nokie; klein.

noöien é; nieuw, pas, eerst.

noönie; tegenwoordig, nu.

no(q)o(q)ie; zooals dit.

o a o aha; indien, wanneer.

obieoe(w)oeha; stoelgang.

ödaq; wegleggen, bewaren, opruimen.

odokie [orokie]; een korten weg nemen, een omweg afsnijden. o e; van, vanaf.

oedaq; op den grond neerzetten, neerleggen, plaatsen.

o e kè è $\mathrm{pa}$ [o e kè è fa]; elleboog.

o ekiedopè [oekietofì]; proef, de proef nemen, beproeven.

o e mahaie; bepraten, vleien.

oemahaoe; of... of; ik weet het niet.

o e nè qie; het haar knippen, scheeren.

o eniekaq; vouw, gevouwen.

oeöbie [öoebie]; doove kool. 
o e o ; stompen, vuistslagen geven.

oepanie (oefanie); likken.

o epè [o efè]; betalen van iets, voldoen.

o e pěhöjaäq [o efĕhöjä̈q]; verdragen, dragen, op zich nemen.

oepoena(ie) [oefoena(ie)]; grootouders.

oe (w) a [oe (w) ऍ]; ik.

o e (w) a ha; voorbijgaan, voorbij, gepasseerd.

o ew ̌̌oew ě; eene ficussoort.

okaie; zooveel mogelijk.

okie; uittrekken van iets dat ergens in of om bevestigd is.

o miekoaqaha; urineeren.

o mö; ophouden, omhooghouden, om iets op te vangen.

öö; pers. vrnwd. van den $2^{\text {en }}$ persoon; gijlieden.

oödokie [oörokie]; op weg afwachten van iemand, in hinderlaag liggen.

o ökie(?); slachten van een dier.

o pahie(j)aka; soekoe (stam).

o p è ka ä q; wurgen.

opo; met iets puntigs krabben, graven of peuteren.

ow ahie; komen.

\section{p}

paämahaie [faämahaie]; bezoeken, op bezoek gaan.

pabèoe; opzetten van eene woning.

paboedajaq [faboedajaq]; vermengd, ondereengemengd. paböha [faböha]; gaar, rijp. V.g.l.: paha/böhaq. pa d a h è boe (w) a [fa d a h è boe (w)ě]; huwelijk, huwen.

padaiejaäq; hangen, opgehangen zijn aan iets.

padiehoie(j)aqä [fariehoie(j)aqä; faliehoie(j)aqä]; verward, door elkander, dooreengemengd.

padiehopie [fariehofie]; bedaard, zacht, stilletjes, langzaam. padiekaä [fariekaä]; tegenpartij, tegenstander.

padoedoie; bij elkander verzameld.

pa doew a ä; het benoodigd materiaal voor het tot stand brengen

van een of ander.

pa èdoha [pà̀loha]; hangen, opgehangen zijn aan iets.

$\mathrm{p}$ a è hi e; bloedverwant (?).

pa èho; verhuizen, naar eene andere plaats overbrengen, verplaatsen. 
p a è i e; overspel bedrijven, buitenechtelijke gemeenschap, minnehandel hebben.

pa èn o e; opzetten van eene woning.

pahabieaäq [pahabie(j)aq]; om het eerst trachten te be-

machtigen; met zijn velen wedijveren om iets meester te worden. pahaboe(w) e; streng, kluwen.

pa(ha)böhaq [fa(ha)böha q]; gaar, rijp, koken, gaar maken. pahad odi e (j) a ä q; vergelden, beantwoorden, vergoeden, weeromgeven.

pahadoho [fahaloho]; pahadoho [fahaloho] èkiedjaie(j)oe; schuldgevoel, berouw.

pahaèkoe; te vuur zetten om te koken.

pahakè(j)aq; het feest gegeven bij het te water laten van een sampan.

pahakie(j)a [pahakie(j)o]; rots, gesteente.

pahakoienanaq; vast, standvastig, bestendig.

pahä ; de korte redevoering gehouden bij het "kaléak(oe)baba" feest.

pahapèaq; in bedwang houden, beletten.

p a h a poeè (q); [f a h a foè̀ (q)]; voltooid, klaar, gereed; ook : verzameld, bijeen.

pahjo [fahje $]$; het van plaats veranderen, zich verplaatsen. pahodaie; staart.

pahoehoedoe [fahoehoeroe]; rollen, voortrollen.

pahoemana; \pm 6 u. in den morgen.

pahoeoenaq; soekoe (stam).

pahoqoekie; met de vuist of knokkels stooten inz. op het hoofd en het gelaat.

pahoraie; den bijslaap uitoefenen.

pa i en ènè a q. [fa ienènè $\mathrm{aq}$ ]; regelen, rangschikken, in orde brengen.

pakahadè [pěkahadè; pakahalè; pěkahalè]; dooden van levende wezens.

pakahopa [fakahofe], omhelzen, in de armen houden. pakaö(w)aq; onder eene massa herkennen, kennis maken

het uit elkander kennen.

pakarahaq [fakarahaq]; overdwars.

pakèho (w)oq; verbieden, tegengaan, verboden zijn.

pakè(j)aq; iets wat men ergens opplakt.

pakèlie $(j)$ a [fakèrie $(j) a]$; ruilen, verwisselen. 
pakie(j)oe; verborgen, verscholen.

pakiemaha; tegen iets slaan of stooten.

pakieno; wedijveren, wie het sterkste is.

pakieopo [pakieofe]]; plat op den buik liggen.

pakoba; achterna komen, iemand achternaloopen om hem in

te halen.

pakoehè [fakoehè]; paal, stijl, mast.

pakoehie(j)aq [pakoehè(j)aq]; roeren, omroeren.

pakoehö(j)aq [fakoehö(j)aq]; aaneengehecht, samenge-

lascht, aangezet, verlengd.

pakoeienanaq; vertrouwen stellen, vertrouwen, lichtgeloovig. pakoenaq; leeren; kèo pakoen aq a iekiedjaieboe [a èkie-

taieboe]; onbeschoft, lomp.

pakoenoejo; uitslag, vurigheid in het gezicht.

pakoeoe(w)aq [pakoeqäq]; gooien, weggooien, werpen, smakken, smijten.

pakoepèq [fakoefèq]; geschil, verschil.

pakoe(w)aq; bevel, last.

pakohaq; verkrijgen, erlangen.

pako(q)öhäq; in bezit genomen, gekregen worden, gevangen

genomen.

pa ko $(w)$ è $h \mathrm{ko}(w)$ è $h$; hinken.

pamahaoema [pamahaoma]; duister, avond.

pamahona [iepamahona]; anders worden, veranderen.

pa mè $\mathrm{m}$ è $\mathrm{o}$; de tong uitsteken.

pana(h) [fana(h)]; schudden, iets of ergens aan schudden. panako [fanako; pěněko; fěněko]; juist, juist van pas,

toereikend, genoegzaam, voldoende, reeds, toereikend, vol, voltallig, in zijn geheel.

panakona [fanakone]]; gelijk, gelijk zijn, gelijk in waarde; $\mathrm{kie}(\mathrm{j}) \mathrm{abaq}$ [kè (j)abaq] panakona [fanakon ̌], zonder wederga; pan a kon a äq [fa n a k on ěäq], evenbeeld, wederga. panaoe [fanaoe]; aanspreken, toespreken.

panapa; uitspannen, uitspreiden.

panè [fan è]; op een korten afstand, dichtbij; hopanè [ho-

fa ǹ̀], genaderd, bijna, nabij.

$\mathrm{p}$ a n è $\mathrm{n}$ è h a i e; bedrog, list, streek.

pa nieha (q) [p a nèha (q)]; spoedig, schielijk, gauw, snel,

haast, spoed.

p a o dè a q; overal in het rond, rondom in het rond. 
paoeho(q); ergens wegleggen, weggelegd hebben om het te bewaren, plaatsen, neerzetten. paоe(w)a [paоe(w) $\succ$ ]; woordentwist bijleggen. pace(w) a ое; schudden, iets of ergens aan schudden. paopajaäq [faofajaäq]; in geregelde volgorde op, in of naast elkander geplaatste, bij elkander behoorende voorwerpen; stapel, stel. pa o pèkie (j) a q; plooi. papa [fafa]; wang. papěrabie; sprong, het springen. pa pè a [f a fè è]; hellend, scheef. pa pèh odie; geraas en getier makend. papoedoe [papoeroe] (grwd. èpoedoe?); vechten, plukharen.

paqjo; stampen, aanstampen.

parabie; stap, schrede.

parahoeie; loeren, bespieden, beloeren.

parako(w)a; in gezelschap van.

pariehoie(j)aqä [faliehoie(j)aqä]; verward, door elkan-

ler, hoviengenerirl.

parie po e poeh; zekere boomsoort met deugdzaam timmerhout. parieqö [farieqü]; doen maken, vervaardigen.

$\mathrm{p}$ a roe pèie [fa roefè i e]; vermengd, dooreengemengd, ondereengemengd.

paroähaja; 12 u. 's middags.

parobiekie; zekere pisangsoort.

paroriepo [faroriefo]; baard, sik.

pè [pè è; aboepè;]; aangeven, aanreiken, overgeven; ha

bo e pè; aan iemand geven, aan een ander geven. pè $(j) a h a[f e ̀(j) a h a]$; zenden van zaken.

pěkaka; gespannen, strak.

pěkakarie(j)aq; in de rondte draaien.

pèn jako [pĕn jako; fèn jako; fĕn jako], te leen, wat terug-

gegeven moet worden, te leen vragen, leenen van iemand. pènohie $(j) \circ[$ fènohie $(j) o]$; begeerig, belust.

piehie [fiehie]; wrijven, knijpen, zacht tusschen de vingers

knijpen, zacht drukken van de ledematen. pi e $(\mathrm{j})$ a ko $(\mathrm{w})$ è q; zekere pisangsoort. piekie(j)aq; uitkloppen van kleedingstukken. piekopieko; eene liaansoort. 
piekoöie; bijten van menschen en dieren.

pienahaäq [p ̌̌nahäq]; rich omkeeren, omdraaien in den slaap.

pieöhaäq; pak, bundel.

piepienaq; gezien kunnen worden, te zien zijn, zichtbaar zijn. poedaq; in water afkooken.

poedarie; borstvin der visschen. (Zie: è poedarie).

poekoie; open en bloot, openen.

poeoenjaq; samenverbonden zooals een rist uien, bladeren van een tak, vruchten aan een steel.

poepoedoe [poepoeroe; foefoeroe]; iemand kwaad doen,

woedend moorden, alles overhoop steken wat men ontmoet

(v.g.l.: papoedoe).

poeqü; vluchten, wegloopen, hard loopen.

poerieho [poelieho; foelieh é]; weduwnaar.

pohaie; mogen.

pohoie(j)aoda; denk er over na, bedenk wel.

pöhöjaq; I gedachte, nadenken, overdenken. II verbeelding, voorstelling, waan.

poporo [foforo]; leugenachtig, leugen.

poöpèkie (j)a q; vouw, gevouwen.

\section{$\mathbf{r}$}

radjo; (mal.), hoofd.

rapat; (mal.), terechtzitting, rechtbank.

t

taka; twintig; een term, die de hoeveelheid te ruilen goed aangeeft, destijds in gebruik bij de bepaling van de ruilwaarde van diverse goederen (de waarde kwam overeen met 20 centen); een gewicht overeenkomende met \pm 5 katis gewicht. tjientjien; (mal.), ring.

\section{w}

wakiepörö [wakieförö]; benauwd, beklemd, aamborstig.

Telwoorden.

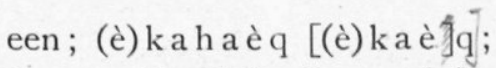

twee; adoe(w)a [a roe(w)a; adoe(w) é]; 
drie; a koloe [iakonoe

vier; a (o) pa [a(o)fa];

vijf; adieba [a rieba; aliebé];

zes; akieäkiena [akieakien $ऍ]$;

$\left.\begin{array}{r}\text { zeven; adieba } \\ \text { arieba } \\ \text { aliebe }\end{array}\right\}$ hie $\left\{\begin{array}{l}\text { adoe(w)a; } \\ \text { aroe(w)a; } \\ \text { adoe(w)e; }\end{array}\right.$

acht; a (o)pa hie a(o)pa [a(o)fa hie a(o)fa];

'negen; a bai ek a h à̀q [k à q];

tien; kiepa(a)oeq [kiefa(a)oeq];

elf; kiepa (a)oeq [kiefa(a)oeq] hie (è) kahaèq, [(è)kaèq].

twaalf; kiepa(a)oeq [kiefa(a)oeq] hie $\left\{\begin{array}{l}\operatorname{adoe(w)a;} \\ \operatorname{aroe(w)a;} \\ \operatorname{adoe(w)} \text { é; }\end{array}\right.$

enz.

twintig; (è) $\mathrm{ka}$ h a è q [(è) $\mathrm{k}$ a è q] t a ka.

een en twintig; (è) kaha èq [(è) ka èq] taka hie (è) $k a h a ̀ ̀ q$ [(è) $k$ a è q];

enz.

dertig; (è)kahaèq [(è)kaeq] taka hie kiepa(a)oeq [kiefa(a)o eq];

een en dertig; (è)kahà̀q [(è) kaèq] taka hie kiepa(a)oeq [kiefa (a)oeq], hie (è)kaha èq (è) ka è q];

enz.

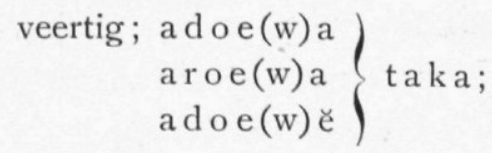

een en veertig; adoe(w)a

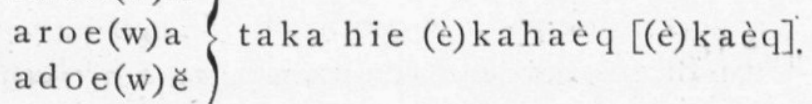

enz.

vijftig; a doe (w)a

aroe(w)a taka hie kiepa(a)oeq [kiefa(a)oeq.

a d oe (w) ě )

zestig; ak ăloe/taka; 广 (axoroe)

zeventig; akoloe taka hie kiepa(a)oeq [kiefa(a)oeq];

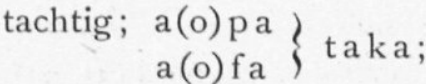

negentig;
a(o)fa $($ o $a$ taka hie kiepa(a)oeq [kiefa(a)oeq]; 
honderd; $\left.\begin{array}{rl} & \text { dieba } \\ \text { arieba } \\ \text { aliebe }\end{array}\right\}$ taka;

$\left.\begin{array}{r}\text { tweehonderd; kiepa(a)oeq } \\ \text { kiefa(a)oeq }\end{array}\right\}$ taka;

vier honderd; (è) kah a èq [(è)kaèq] koedodoka [koedoroka]. (elke toon en vinger voor een "taka" gerekend).

B. Z I N N T JES.

1. Hoe heet gij? Hoe heet hij? Haie nie(j)omoe; èèho niejo $\operatorname{die}(j)$.

2. Hoe heet dit eiland, dit Haie nie(j)o kèpoe èie, èloppo landschap, die doesoen? èie, kaoedara èana.

3. Waar woont gij?

4. Wilt gij klappers ruilen tegen koralen; zoo ja, hoeveel klappers krijg ik dan voor vijftien snoeren koralen?

5. Zijt niet bevreesd, ik zal U geen kwaad doen.

6. Hoeveel bedraagt het aantal inwoners van deze kampong?

7. Hoe heet degene, die dit huis gebouwd heeft, wien dat huis toebehoort.

8. Zijt gij gehuwd?

9. Hoeveel kinderen hebt gij ?

10. Gij moogt niet daarheen gaan.

11. Wees niet boos op mij.

12. Ik heb goederen van den overwal medegebracht, ze zijn mooier dan die welke $\mathrm{U}$ door den chinees N. N. zijn verkocht.

Dl. 71 .

Iejahaie èoebaboe (iejahaie (h)èaboebaja).

È̀ie(j)o öö koehèdieawa ie(j)opoh èdolèdolè apèakoenanaq apieha èpoh aoe(w)odie ie(j)oho dolè dolè kiepa(a)oeq hie adieba.

$\mathrm{Ie}(\mathrm{j})$ araq èkahaho kieabaq oewa boeadomoe.

Apieha èomona oekakaq ieho kaoedara ietèq.

Haie nie(j)o oekaka kiepaènoe èoeba èie, èoeba èana haie.

Öö ho maähona [padahèboe(w)a].

Apieha èaraboe.

Kie(j)abaq pöhaie awa(h) iedjiedja(h).

È(ie)(j)araq (è)pahoe(w)a ie öö.

$\mathrm{Oe}(\mathrm{w}) \mathrm{a}$ kienaqie(j)aie èdoboe koedè kahapa kaoe(w)a koeiena(na)q ie(j)o ho oedoboe kjahi ie(j)o moö kie(j)odie(j)aäqha. 
13. Hoeveel kains heeft die maleier gekocht?

14. Ik wil naar die doesoen; hebt gij lust mede te gaan?

15. Dit is mijn huis; die jongen daarginds is mijn zoon.

16. Hij is uw neef, zij uwe nicht; die is zijne moeder.

17. $\mathrm{Mij}$ is een ongeluk overkomen.

18. Wie heeft deze sampan gemaakt?

19. Deze is mijne lans, gene die van mijn zoon.

20. Ik wil dit zus en dat zoo hebben.

21. Hebt gij mij begrepen! neen nog niet mijnheer.

22. Morgen ga ik naar die doesoen.

23. Zoo even gewerd mij het bericht van het vergaan van de prauw pentjalang toebehoorende aan dien maleier.

24 . Voor niet en te vergeefs heb ik op U gewacht.

25 . Ik wil volstrekt niet hebben, dat gij aldus handelt.

26. Van eene moeder.

27. Zooveel mogelijk moet ge de bevelen van uw hoofd opvolgen.

28. Twee maal twee is vier; vijf $\min$ één is vier; twee maal twee is vier; acht gedeeld door twee is vier.
Apieha èkain èodie èko(w)èq èana.

$\mathrm{Oe}(w)$ a kahaja iekaoedara èana; öö kahapie abako(w)a ieoe(w)a.

Èie èoebaäoe èana èpaiedjiedjah èaraèmanieaoe.

$\operatorname{Kie}(\mathrm{j}) \mathrm{e}$ èlahaoeboe, èhöda èana èlahaoe öö, èana ènaènadie(j)ě.

Oe(w)a kamanaä kie(j)oha.

Haie kieparieqö èloha èie.

Èie kaäjoqaoe koedè(j)a w(a). araaoe èmanie.

$\mathrm{Oe}(\mathrm{w}) \mathrm{a}$ kiepadjiejoa èie oeoboe no(q)o(q)ie oe(w)a kiepadjiejoa èa(q) oeoboe noaha.

Öö ho makaoe(w)a(q)oe(w)a, kèo kaoepè biedie.

Naoemana oebaha kaoedara èana.

Nèènie(è) èdohoieaqö èloha èko(w)èq èana kiekèo(w)a.

$\operatorname{Kie(j)abaqä~kie(j)a~kèho(w)a~}$ mokieaoe ie(j)ěmoe.

Kie(j)abaq wahapie koeienaqie(j)o kaboeaboe kienoaha.

Kahaèq ènaèna.

Okaie öö jadaqèiedjie radjoboe.

Anohienoe(w)a adoe(w)a a(o)pa ; adieba kakoebèodaq kahaèq kabie(j)a a(o)pa; adoe(w)a kamakamako ie(j)o adoe(w)a 
kaä(o)pa; a(o)pa hie a(o)pa kamieha $\operatorname{adoe}(w) a$ ie(j)a a(o)pa.

29. Zonder hulp van anderen hebt gij den diefstal niet kunnen plegen.

30. Gij of ik; hij en ik.

31. Wat mij betreft.

32. Wat zou het.

33. Oók ik wil er heen.

34. Kasian die arme meid.
Oakèo (è)koehaie oèka(q)ka(q) kie(j)abaq owobèho.

Oemahaoe öö oemahaoe (oe)wa; kie(j)a hie oe(w)a.

Oe(w)a haba.

Hakie oe(w)a.

Hèoe(w)a kahaja iedjiedja(h) of: oe(w)a kahajaba.

Kaä èbahoka ie(j)ohöda èana.

C. RAADSELS (Èadoehoie; Èaroehie; Èkoehie(j)o).

1. Èèhie(j)o èhopo kie(j)oe adoe(w)a.

Wat heeft twee windgaten?

Oplossing: èpanoe - de neus.

2. Èkafalafie $\mathrm{a}(\mathrm{o})$ fahie $\mathrm{a}(\mathrm{o}) \mathrm{fa}$ èfakoehè.

Welk stoomschip heeft acht masten?

Oplossing: èhoqä - de inktvisch.

3. Èoeba kahabaoeba kahaèq aèkadoba barieboeriboe èka(q)ka(q) kiekie(j)a iehodie(j)a.

Een woning met één deur, waarbinnen ontelbare personen verblijf houden.

Oplossing : èoeba oekieho - mierennest, termietenheuvel.

4. ̇̀ka(q)ka(q) kahaèq kěno kokona iekoekonie(j)a èèkadjie(j)a. Een persoon, die, al etende, zijn gevoeg doet.

Oplossing: èokohè - schaaf.

5. Èmèo kahaèq kaoe(w)ie kieèhèkoe(q) èhokoeoekoe(w)气 kěbahè èmèo kaiekoko njamaooefanie hèie $(\mathrm{j})$ odie $(\mathrm{j})$ è.

Eene zwarte kat, zittende op een afgesneden stuk hout, wier achterste wordt gelikt door eene roode kat, die aangeloopen komt.

Oplossing: èpèrie( $\mathrm{j}$ )oq èdiekiehooe $(\mathrm{j})$ obie - een aarden (metalen) pot die op een treeft te kook wordt gezet. 
6. ̇̇ka(q)ka(q) kahaèq kaoe(w)ie èoedoedie(j)a kaoedahjo èkiedjaiedie(j)a kaäoeba kahabaoeba epoeroeroeie èoebadie(j)a.

Een persoon met een zwart hoofd en witten buik, wiens woning op een dakbedekking gelijkt.

Oplossing: èpo(ö)kaha - spin.

7. Ehewa oekoeo kahai keaba kia eoeoe kabahaela emas hi eperak.

Een vrucht zonder steel, inhoudende goud en zilver. Oplossing: eara ajamoe - kippenei.

8. Kahai ekaka kia kinono eoea kia kibibitto ebo ke afe amaohka kia kia kiekaha ikoädia.

Een persoon, die voedsel tot zich neemt en water drinkt doch zijn gevoeg doet uit zijn mond.

Oplossing: ekidihopa - aarden (metalen) pot.

9. Kahai ekaka afe akapajo kia kaboehohora kabaäo.

Een persoon, die, wanneer hij gestoken wordt, zingt en daarna sterft.

Oplossing: epeo - kikvorsch.

10. Kikia ekaka kahai aipoeroe ika aböhada kaboelo maänapona ke afe akapoeroe kia keaba ihoea jonia.

Een persoon, die, wanneer hij ons steekt, ons doet weenen, doch die niet geraakt wordt, wanneer wij naar hem steken.

Oplossing: ekanoa - rook.

11. Kikia kahai eoeba aroeada eoekoena ke epoeroeroeie dia pamohomohoina epoeahhadia kaboepoehai boekokoi.

Eene woning op slechts twee stijlen en met eene veelsoortige dakbedekking, welke zich bewegen kan.

Oplossing: ekiadoboe - kip.

12. Kikia ekaka aiîkada elopo kapehea earoehe ikaä oe beloa keapo elopo koeanaha epao jonia.

Een persoon, die bij het aanbreken van den dag zich heen en weer beweegt en zingt aan den oever van de rivier maar bij het invallen van den avond verlamd raakt.

Oplossing: epoeroeroei oebaka - ooghaartjes.

13. Kikia aroea ekaka afeaiîka elopo aböhada epapoeroe edioboedia. 
Twee personen, die, den ganschen dag door, niets anders doen dan met elkander twisten. .

Oplossing: ekaä — mond.

14. Kahai ekaka kia kaäbadjoe ke epoe kia ke akakapoe kia kaboedapoe iara eabadjoe.

Een persoon, die jong zijnde, een baadje draagt doch oud wordende dat kleedingstuk aflegt.

Oplossing: eabeha — bamboeriet.

Met «badjoe» wordt het dekblad (hulsel) van het eetbaar uitspruitsel bedoeld.

15. Kahai ekaka kaäoeba eoeba karoemimi kaikoko ke afe akadodo kia dipahawa.

Een persoon, die in eene woning van rood glas huist en boos wordt wanneer men hem aanvat.

Oplossing: eobie — vuur.

16. Kikia ekaka keaba kapoehai boeoea epamania ke afe abahabario kia ekoa kaboekoheaähoi kidara.

Vele personen, die, al gaande, een dak vervaardigen.

Oplossing: ekahino - witte mier.

17. Kahai ekaka kaäkabo ihea oekoeo.

Een persoon, die een groot net op een boomtak vervaardigt. Oplossing: epoekaha - spin.

18. Kahai ekaka kaäpoeroeroe kaikoko afe akararakoei kia kabaditahaähoi joka. .

Een persoon met rood haar, die, wanneer men hem schudt, onmiddelijk daarop steekt.

Oplossing: eoebi — salak (e. s. v. rottanpalm met eetbare vrucht.)

19. Kahai ekaka kia kinono ke keaba ipoehai meka kekia keo napona abeo kia kaboedohai ekaka kidara eëodia.

Een persoon, die eet en braakt doch niet zijn gevoeg kan doen; braakt hij, dan wordt zulks door een ieder gehoord. Oplossing: epoöhki - geweer.

20. Kahai eapoeq keaba hinoeki enoeoenia afe abaära kia ka(ma)hapi ekaka moeno earadia.

Een slang van géén geringe afmeting, wier eieren gaarne door den mensch worden gegeten.

Oplossing: eopa - kalebas. 


\section{VERHALEN (Ekoedaäjo).}

\section{Ekoedaäjo ekoanoe kipahóna hi ekaka. Tjeritera tikoes kawin sama orang.}

E. Kikia hale ilopo eana aroea epoinamo moö, M. Adalah doeloe dinegrie itoe doea gadis jang E. káoea epoeahhadia, kamoephi ipahona hi epoM. amat elok roepanja tiada maoe kawin dengan boeE. nanami kidara ilopo eana, ke kikia pe ilopo M. djang semoea di negrie itoe tetapi adalah di negrie E. eana kahai ekaka, moö kioha ikarara epoeahhadia, M. itoe satoe orang jang boeroek sekali roepanja

E. kia kamoephi boekokoi dakioho, iarakoea M. dia tiada maoe berdjalan siang soepaja djangan E. kiepöa kia ekaka, be mania kia, ke kaoea M. di lihat dia orang djangan maloe dia tetapi bagoes E. ikarara eohoradia, kia kaha dakóahia ioeba M. sekali njanjiannja dia berdjalan malam diroemah E. kapoinamo aroea nèèni, ke keaba iahapi kia boekoi M. gadis gadis doea tahadi tetapi tiada maoe dia boeka E. eoeba jonia, kaeanaha diboehohora ekaka kioha M. roema sama dia djadi menjanjilah orang boeroek E. neëni, kamahapi kapoinamo eana jonia, ia boeM. tahadi djadi maoe gadis gadis itoe sama dia di boeE. koi eoeba, ke keaba eobi iho eoeba, M. kanja roemah tetapi tiada api didalam roemah E. kanoaha iabaetara hia iphoko, moko hinoea kia M. bagitoelah main main dia didalam banjak kali dia E. ikoea ioeba kapoinamo eana, ipaänoha kia,

M. masoek di roemah gadis gadis itoe bakawin dia orang E. ke iaoeijaha moko hinoea kia ioeba eana, M. tetapi maskipoen banjak kali dia di roemah itoe E. kaoepe ipakawa kapoinamo epoakha oekaka eana, kaM. belom tahoe gadis gadis roepa orang itoe ba E. noaha na ekaka ikaoedara eana, daboeodo M. gitoe djoega orang di kampoeng itoe lama lama E. beteekent Engganeesch.

M. " Maleisch. 
E. kamoephoei ekaka kia iabapoea epoeahhadia, kamaniaha M. diintai orang dia melihat roepanja maloelah E. kia be ipoa ekaka eitabopo epoeahhadia, be M. dia sebab dilihat orang kaboeroekan roepanja sebab E. keaba ipoehai bahaopi enaniania, di moenaha ehobe M. tiada bisa tahan kamaloeannja di ambillah doeri E. eajo, ikitahaäoda iiodia, di koeboea iho

M. ikan ditjoetjoekkan di pantatnja masoek kedalam

E. eëkaha kabapadi ekoanoe idita, noaha eadohoda

M. djamban mendjadi tikoes disana bagitoe penghabisan

E. oeia ekaka eana iabapadi ekoanoe, kamoho kapoiM. hal orang itoe mendjadi tikoes tetapi gadis

E. namo neëni iabaoökahhai kia ekaka, kamaniaha kia M. gadis tahadi diketawai dia orang maloelah dia E. be kia kepaäno hi ekoanoe, kaeanaha dipoeaka

M. sebab dia bakawin dengan tikoes lantas berangkat E. kia aroewa jana iohki, be kia kahapi kaha M. dia berdoewa ka tepi laoet sebab dia maoe pergi E. ikimo kamaäko kia, ke kahai keaba M. di negri tiada ketahoean bernang dia tetapi satoe tiada E. iaäo kabiada kia iohki, ke hemoö kahai M. koeat tinggallah dia di tepi tetapi jang satoe E. iaboehkoda jana, ke edioboe enania moö M. teroes pergilah kesana tetapi sebab maloenja jang E. kahai neëni kakoekoeöha ekitaida, kamanoenoehi iabaM. satoe tahadi soesahlah hatinja di mintaknja menE. padi kia eëa, kakoeinana kabapadi eëa kia M. djadi dia batoe djadi betoellah mendjadi batoe dia E. noöni i kioa, ke anonia hemoö kaähko M. sekarang di teloek Kioa tetapi kawannja jang bernang E. iabakoa ikaoedara kahai, ke kia kahahona kaha M. sampai di kampong satoe tetapi dia takoetlah pergi E. ioeba oekaka, beo ipoeroe kia, kaeanaha M. diroemah orang kalau kalau di boenoeh dia djadi E. iminaäwa kia ihea oekoeo kahai, iabaja idita, M. naiklah dia kedahan kajoe satue tinggal di sitoe E. kamoho kahai kaähoeoi kajai itopo kaha M. maka satoe perampoean toea toeroen di bawah pergi E. mahanoeani kaoedara, ke afe adohoda ihoadi, M. menjapoe kampong tetapi kalau soedah di sapoe 
E. kahibadodoboeipe, be epoeroekoeo kidadapoe kia

M: kotor lagi sabab daoen kajoe djatoh djatoh dia

E. koede itebe, kaboepoaha kaähoeoi itebe, kahai

M. dari atas dilihatiah perampoean toea keatas satoe

E. epoinamo kihehekoe ihea oekoeo eana,

M. perampoean gadis doedoek didahan kajoe itoe

E. iabahadi kia iajai itopo, iabakoeaha ioeba-

M. di panggillah dia toeroen kebawah masoeklah di roeE. dia hi ipeda eoea jonia, ke keaba

M. mahnja dan di kasilah makanan sama dia tetapi tiada

E. ipakawa dadoedia kikia ekaka mohona ioebadia,

M. di ketahoei lakinja ada orang lain di roemahnja

E. ke daboeodo ipakawaäwana, kahipahonaha kia

M. tetapi lama lama di ketahoeilah dan di kawinkan dia

E. hi eponanami kahai, daboeodo kabaäraha kia

M. dengan boedjang satoe lama lama beranaklah dia

E. kabaäraha earadia akiakine, ke daboeodo ka-

M. dianakkannja anaknja anam tetapi lama lama soe-

E. mahapiha dadoedia moeno honania eana hi

M. kalah lakinja memakan bininja itoe dengan

E. ekararadia, kaboedohoi honania kamahapi kia,

M. anakanaknja di dengar oleh bininja maoe dia

E. boepoea hi ekararadja, ke keaba ipoehai,

M. lari dengan anak anaknja tetapi tiada bisa

E. kaeana inonaha kia hi ekararadia jo

M. maka di makanlah dia dengan anakanaknja oleh

E. dadoedia, ke keaba iboeododa eabaäodia kahiböda,

M. lakinja tetapi tiada lama matinja hidoep

E. ke dadoedia hi kaänonia hokaha

M. poela tetapi lakinja dengan kawannja soedah pergi

E. moho kaeanaha eoepoeadia hi ekararadia

M. lain (tempat) lantas larinja dengan anak anaknja

E. eana, iamakoea iho oelohao kabaehko jana

M. itoe menoempang di dalam sampan pergi ka

E. ilopodia iabapoa noena hi kidara kaä-

M. negerinja mendapatkan iboenja dengan semoea kawan

E. nonia, noaha ekoedaäjo ekaka moö kipahona

M. kawannja demikianlah tjeritera orang jang berkawin

E. hi ekoänoe.

M. dengan tikoes. 
epoinamo; gadis.

kapoinamo; gadis gadis.

eara; anak.

ekarara; anakanak.

kabaära ; beranak.

kabaäraha; beranaklah, menganakkan.

II. Ekoedaäjo epoeroehi

Kamoeki

Kapoe

Tjeritera

boeroeng helang

memakan (mentah)

anak anak

ikanaja äona.

sampai habis.

E. Kikia hale ilopo eana pane i Boeo-boeo kahai

M. Adalah doeloe di negrie anoe dekat di Boeo-boeo satoe

E. kaoedara, enjiahha oekaka kaäphia, kamoho kapoe

M. kampong tempat orang berladang tetapi anak

E. kikiada ioeba iomo kahai kaähoeoi,

M. anak adalah di roemah di toenggoe satoe perampoean

E. daboeodo iabaäoha kaähoeoi eana,

M. toea lama kelamaän matilah perampoean toea itoe

E. kakeaba ekaka komoa kapoe abaha

M. djadi tiada orang menoenggoe anak anak kalau pergi

E. kahoamana ephia, kamoho kahai keëpa epoeroehi

M. bapaknja keladang maka satoe boeroeng helang

E. kipopoa kapoe ioeba keaba moö komo,

M. melihat anak anak di roemah tiada jang menoenggoe

E. kia kamahapiha moeno kapoe, di boekaida

M. dia maoelah makan anak anak di tangkapnjalah

E. kahai maaona jahaioebadia iamano idita,

M. satoe di bawanja karoemahnja di makannja disana

E. noahana edioboedia jooekahaokahao, kapanene ikanaja

M. bagitoelah dia bikin tiap tiap hari ampirampir habis

E. kapoe eana, kiekoekoeohoi ekitai oekaka moö ka-

M. anak anak itoe menjoesahkan hati orang jang be-

E. äoeba idita, kabaoadiha emakawa, kamoeinoi elopo

M. roemah di sitoe mentjarilah pikiran menggali tanah

E. enjiahha kapoe, abaha kanapoe ephia,

M. tempat anak anak kalau pergi orang toea keladang

E. kaboda idita eoea panako hi kapoe

M. di simpan di sana makanan tjoekoep boeat anak anak 
E. eana, kanoaha ipakoeada kapoe kidara ihopa

M. itoe bagitoe di kasi masoek anak anak semoea di dalam E. oelopo eana, kabaiha epoeroehi kaboepoa

M. lobang tanah itoe datanglah boeroeng belang melihat E. hokeaba kapoe ioeba, iamana epo

M. soedah tiada anak anak di roemah di ambil kelapa E. eahhainia kamoekoekoe kidoeia eanipa oekaka, M. moedanja menoeroet saperti penokoknja orang

E. kaboedohoida kapoe eana, kaboeoea, abai

M. di dengarlah anak anak itoe katanja soedah datang E. naenai, kapakaiwaha epoeroehi enjiahha kapoe, M. mak saja (lantas) taoelah boeroeng helang tempat anak E. kamanaha kia iamainoi, inaaona kahai, jaha M. anak pergilah dia menggali diambillah satoe ka E. ioebadia, kamoeno, kahinoahana edioboedia kaM. roemahnja dimakannja bagitoe poelalah dia bikin mengE. moekanaja kapoe, kamoho ekaka kidara kaparoeroe M. habiskan anak anak maka orang semoea berkoempoel E. okaha bapoeroe kia ioebadia, ke keaba M. hendak memboenoeh dia di roemahnja tetapi tiada E. ipoehai be amoehonaekina ekite enjiahhania, M. bisa sebab tinggilah kajoe merbau tempatnja

E. kamoho ekoanoe kahai kaboeoea noöi jona:

M. tetapi tikoes satoe membilang bagini sama dia orang E. „Kaoeada oekoehai arioe oebaiteëi kia”, kaM. baiklah (saja) toeloeng kamoe (saja) tipoe dia perE. mana ekoanoe itebe, kaboeoea noöi jo epoeM. gilah tikoes keatas membilang bagini sama boeE. roehi : "nane oepoa pe eheoekoemoe", M. roeng helang mari (saja) lihat doeloe koetoemoe E. kaboepe epoeroehi epaäepania jo oekoanoe, M. di kasi boeroeng helang sajapnja sama tikoes E. kamoho ekoanoe kaboehohoka epoeroedoei M. tetapi tikoes memotong motong boeloe boeloe E. oepaäepania epoeroehi eana ikanajaäona, iadohada M. sajapnja boeroeng helang itoe sampai habis sesoedah E. eana, kamoeëhaha ekoanoe epoeroehi, kapoeoeda M. itoe menerdjanglah tikoes boeroeng helang djatoh E. itopo, kamoho ekaka itopo kapakahadeha kia M. kabawah maka orang di bawah memboenoehlah dia 
E. iabaäo, ke kahai kakeo kai

M. (sampai) mati tetapi satoe perampoean boenting datang E. idita akaha bahaori earadia jo oepoeroehi, M. disitoe hendak membalaskan anaknja kepada boeroeng E. kabipoeha kia, ke kapikobaha ekanoeoenoe

M. memotonglah dia tetapi terperetjiklah koekoe

E. oepoeroehi iho oekitaidia, kaboepedaiha ekitai-

M. boeroeng helang kedalam peroetnja belahlah

E. kabake, kabaäo idita, noahana eia oekoedaäjo

M. peroetnja matilah disitoe bagitoelah hal tjeritera

E. epoeroehi eana, ke noöni kikia da elopo

M. boeroenghelang itoe tetapi sekarang ada lagi negerie

E. eana moö kanio eanoenoejoe poeroehi pane

M. itoe jang bernama pemotongan boeroeng helang dekat

E. i Boeoboeo.

M. di Boeoboeo.

Kabake; iaitoelah terpakai mendjadi kata pengganti kaädaän boeat orang jang menanggoeng soesah seperti orang sakit, jang mati jang baroe kematian atau orang jang roepanja šoesah.

\section{Ekoedaäjo ekoeaha ediho. Tjeritera permoelaän gempa.}

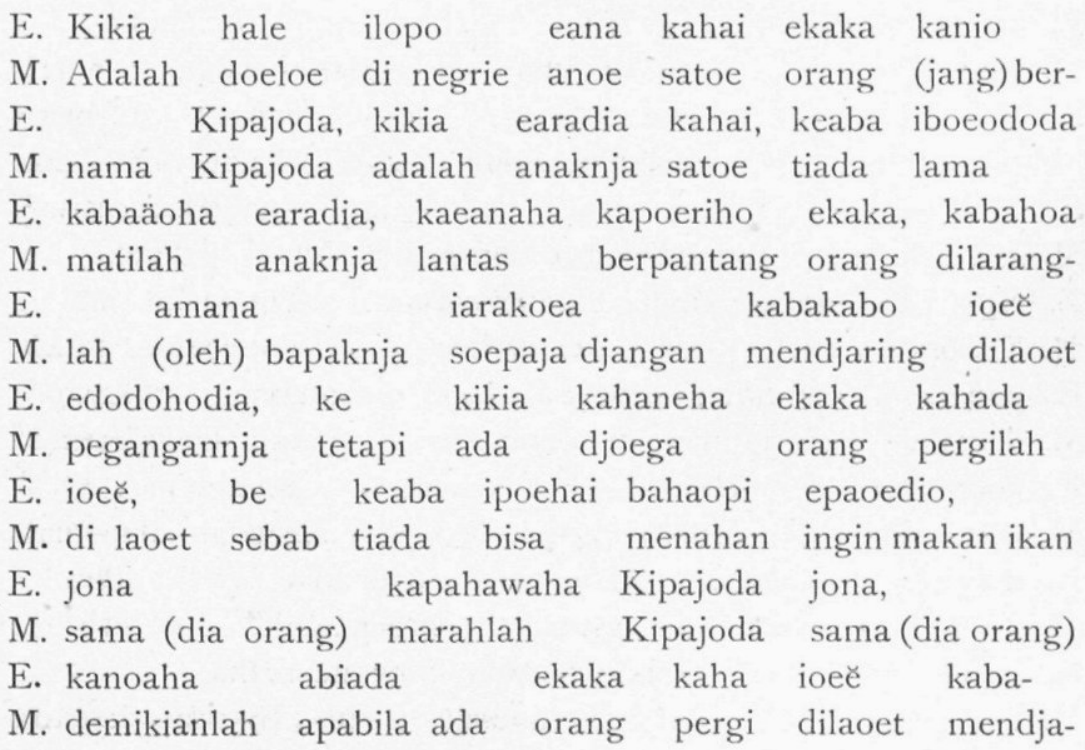


E. kabo kapahowaha Kipajoda, eana eahhadia kamimihi

M. ring marahlah Kipajoda itoelah sebabnja bentji

E. ebahhau kaänonia jonia, dimoephoeiha kia noöi

M. hati kawannja sama dia di tipoelah dia bagini

E. edioboeda, kamoeinoi elopo kahibahapoei itebe

M. di bikinnja di galinja(lah) tanah ditoetoepnja lagi diatas

E. iarakoea kapöa, kamana ekaka kahabakabo

M. soepaja djangan kelihatan pergi orang mendjaring

E. ioě edahoa Kipajoda, kamoho elaäoda

M. di laoet (jang) di larang Kipajoda maka didapatnja

E. eajo di paböha ikahakoda ehopo oelopo, kapanihana

M. ikan di panggang di sebelah lobang tanah sigerahlah

E. kabai Kipajoda kapoeloi kaboedodo ebohe kaha-

M. datang Kipajoda meratap memegang toembak melihat

E. bapöa ekaka kila eajo eana, ke edioboe eani-

M. orang dapat ikan itoe tetapi sebab lekas

E. mohhoinia, keaba ipöpöa ekoa, kaeanaha kake-

M. (boeroeboeroe)nja tiada dilihat djalan lantas terpe-

E. poaha kia jana ipoko, kahipanihana kaänonia

M. rosoklah dia sampai kedalam lekas djoega kawannja

E. boekao ehopo elopo eana, kanoaha eiadia, ke

M. menoetoep lobang tanah itoe bagitoelah adanja tetapi

E. noöi eidji Kipajoda koede ipoko: "aboha be

M. bagini kata Kipajoda dari dalam soedah sebab

E. aroe hobaoboe noaha, abadohoi, amaämina

M. kamoe soedah bikin bagitoe dengarlah kalau soenjilah E. oea ke oea hokeorada, ke abia da oea, M. saja tetapi saja soedah ilanglah tetapi kalau lagi ada E. aroe kainonoana," iadohoda eana kamoeinoi M. saja kamoe merasa nanti sesoedah itoe digali

E. Kipajoda elopo eana kamoekokona i Poepoeko, ke

M. Kipajoda tanah itoe keloearlah di Poepoeko tetapi E. panena epainononia ioebadia, kahimainoi kamoe-

M. dekatlah perasaännja di roemahnja di galinja lagi (lantas)

E. kokonaha i Hoköa, kapakaoeaha homimina

M. keloearlah di Hoköa di ketahoeilah soedah djaoehlah E. kia koede eoebadia, koeanaha eaoebadia idita, M. dia dari roemahnja lantas beroemahlah dia di sitoe E. keaba iboeododa kaboekoeda eiadia idita jo M. tiada lama di kasi tahoelah halnja di sitoe kepada 


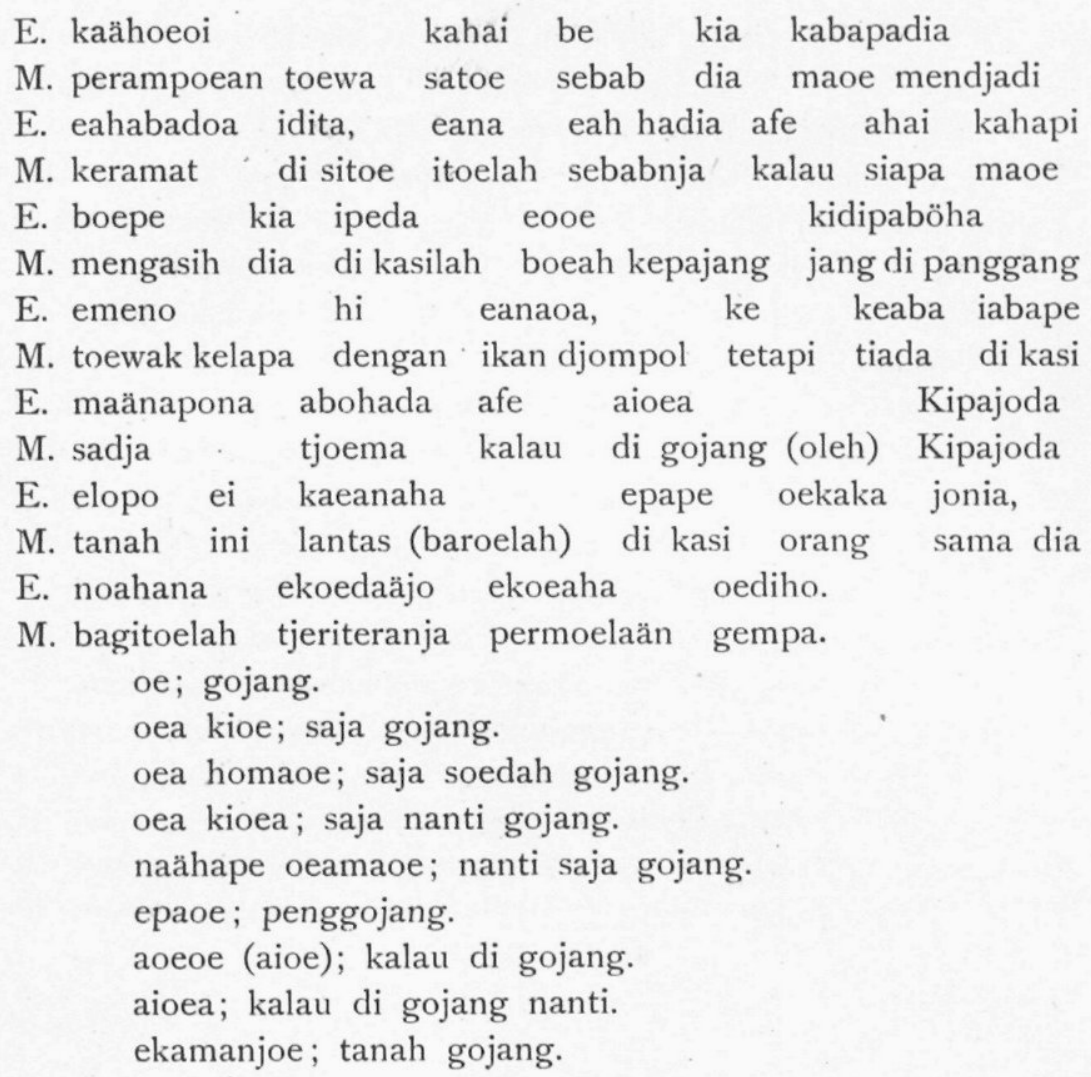

\section{Eahhadia bemanio Doepaoba ekoeroe Koma. Sebabnja bernama Doepaoba oedjoeng Koma.}

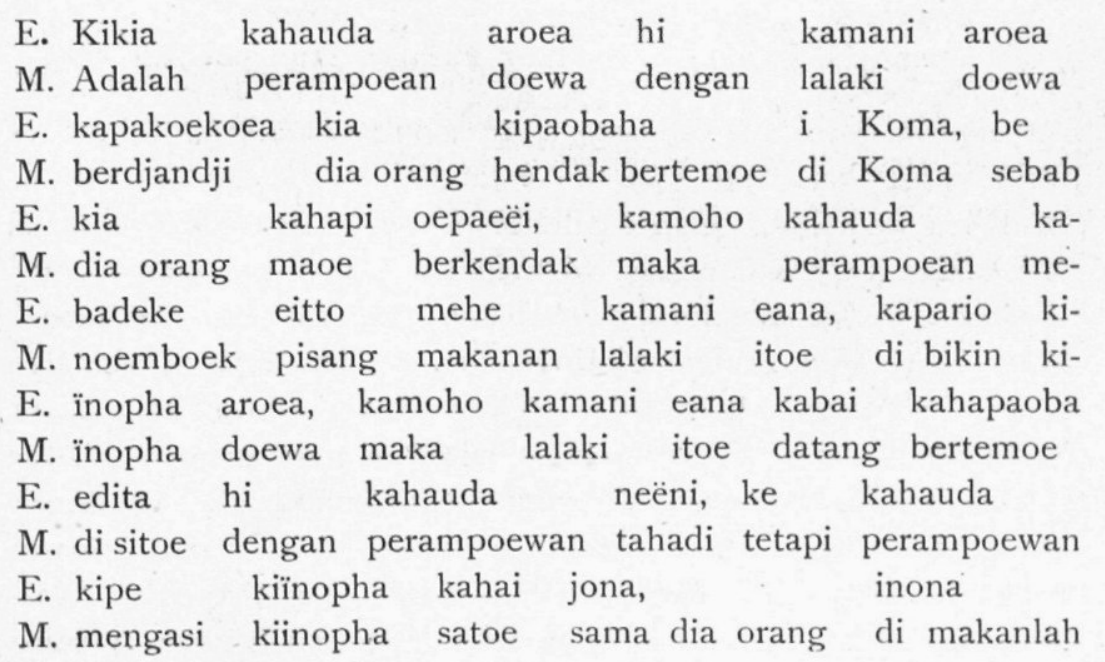


E. ke kahai iabaoda kia mehe naoemana, kaiïka

M. tetapi satoe disimpan makanannja beresoek teranglah

E. elopo, kamoho kamani eana kahapi kahoea ioebada,

M. doenia lantas lalaki itoe maoe pergi diroemahnja

E. kaeanaha di pakene hi kahauda aroea eana

M. lantas bermohon dengan perampoewan doewa itoe

E. kaboepe kahauda eana kiïnopha jona,

M. di kasilah (oleh) perampoewan itoe kiïnopha sama dia E. ke kamani kaboepoekaida eoea eana,

M. orang tetapi lelaki memboekalah makanan itoe

E. kaboepoaha enonoa ehoka, kapahawaha kia

M. dilihatlah (bekas) makanan lipas marahlah dia orang

E. jo kahauda eana, diboepoeaha jana ioebada,

M. sama perampoewan itoe larilah ka roemahnja

E. di poeaka baha kahauda eana ioebada,

M. pergi djoegalah perampoewan itoe karoemahnja

E. noahana eahhadia beianioha ekaka "Doepaoba»

M. bagitoelah sebabnja diseboet orang Doepaoba

E. ekoeroe Koma, kamoho kiïnopha kabapadiha eëa.

M. oedjoeng Koma tetapi kiïnopha mendjadi batoe.

Kiïnopha; satoe matjam makanan orang Engano jang di bikin dari pisang jang soedah masak di toemboek tjampoer dengan ampas kelapa lantas di boengkoes besar besar di masak atau di panggang.

\section{Epakodai ekohha eapita ekoko hi \\ Permoelaän penjoe oedang karang ikan boental dan edahaijo. \\ biawak.}

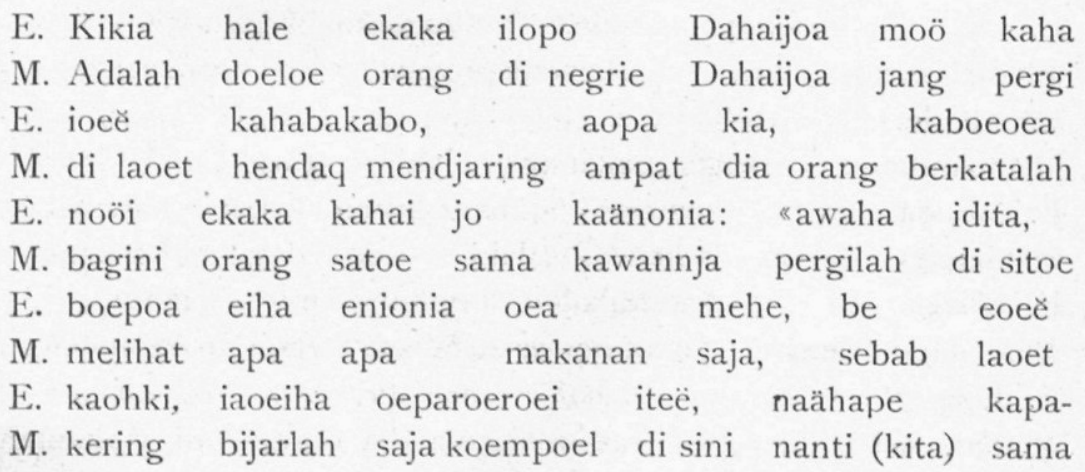


E. hare moeno, kamana moï kahai kabaoahki eei

M. sama makan pergilah jang satoe memoengoet binatang E. oee iabape jo anonia neëni, kamokoha edi

M. laoet di kasi sama kawannja tahadi banjaklah jang E. paroeroeidia eana, ke ikanajaä da

M. di koempoelnja itoe tetapi di habiskanlah (oleh)

E. anonia keaba ipe kia, kaeanaha kapahawaha

M. kawannja tiada di beri dia lantas marahlah

E. kia jo anonia eana, kabaoadiha eamakawa, ka-

M. dia sama kawannja itoe ditjeharilah pikiran ka-

E. boeoea noöi jo anonia: "kako pe boepoea

M. tanja bagini sama kawannja kita tjoba doeloe lari

E. iteë, afe ahai moö eoö," kakoemo kamoeoöno

M. disini kalau siapa jang koewat ditjobalah tiada koeat

E. anonia, moö kaiteëi kia neëni, kahiboeoea jo

M. kawannja jang menipoe dia tahadi diabilang lagi sama

E. anonia: "kaoeada oeabapadi eajo, afe abaohi

M. kawannja baiklah (kamoe) mendjadi ikan kalau kering

E. eoeě, naäni kaboepoeroeha oö ekaka", ka-

M. laoet kelak di boenoehlah kamoe (oleh) orang be-

E. koeinana do edioeadia, kabapadiha anonia eajo

M. toellah seperti dia bilang ìnendjadilah kawannja ikan

E. kanio ekoko iadohoda eana kahibapadi

M. bernama ekoko (ikan boental) sesoedah itoe mendjadi

E. ha kia eapita, kamoho kaänona aroea

M. lagi dia oedang karang maka kawannja doewa

E. kabakabo, di baita eajo moko, kakoko hodaha

M. mendjaring (lagi) mendapat ikan banjak (lantas) besarlah

E. eoeě, kaeanaha dimoena, elaäoda eajo, kababelai

M. laoet lantas diambillah di dapatnja ikan dibelahnja

E. hi kahapakkoea eënonia, ke ekaka moö kahai

M. dan memboeang sisiknja tetapi orang jang satoe

E. kia kipakkoea eëno oeajo eana ibakadia, kamoe-

M. dia boewang sisik ikan itoe di matanja di selam-

E. kenoha iho oeě, ke keaba ipoehai ipeora,

M. kanlah kedalam laoet tetapi tiada bisa tanggal

E. noaha moko hinoea kahi, keaba ipeora, koenanaha

M. bagitoe banjak kali djoega tiada tanggal lantas

E. di boeoea jo anonia: "keaba ihipoehai peora

M. dia bilang sama kawannja tiada bisa lagi tanggal 
E. eëno oeajo koede ebakau, hi afe oena kia

M. sisik ikan dari matakoe dan kalau saja bawa dia

E. ikaäkihi kahiba poehoda, kaoeada oeaäoeba iho

M. di darat makin sakitlah baiklah "saja beroemah di

E. oeě iarakoea kahibapoeho, iadohoda eitjidia,

M. laoet soepaja djangan sakit lagi sesoedah berkata

E. kakoemino kia, kamoena epoeroe oebaba kamoekopia

M. di selamkan dia diambil daoen birah ditoetoepkan

E. ikoekania, kahikoemino, kaeanaha kabapadi kia

M. di belakangnja di selamı lagi lantas mendjadi dia

E. ekohha, ke anonia kahai kaboepoa hokeora

M. penjoe tetapi kawannja satoe melihat soedah hilang

E. kaänonia kidara, kapakkoeada eajo, di moena ekari-

M. kawannja semoea di boewanglah ikan di ambil rotan

E. hoida, kaboekitaha iiodia, kaba-

M. pentjoetjoek ikannja di tjoetjoekkan di pantatnja men-

E. padiha kia edahajo, kabapoea janaikokoeë, noahana

M. djadilah dia biawak larilah kahoetan demikianlah

E. ekoedaäjodia.

M. tjeriteranja.

kino; selam.

kamoekino (kakoemino); menjelam.

kahamakino; hendak menjelam.

kopi; toetoep.

kamoekopi; menoetoep.

kahamakopi; hendak menoetoep.

kamoekopia; menoetoepkan.

homoekopi; soedah tertoetoep.

eanopi (earopi); penoetoep.

kitaha ; tjoetjoek.

kaboekitaha; mentjoetjoek.

kababoekitaha; hendak mentjoetjoek.

oea haboekitaha; saja soedah mentjoetjoek.

oea kikitahaäoa; saja hendak mentjoetjoek.

eakitaha; pentjoetjoek.

\section{Ekoedaäjo epaeëi oeapoe hi ekaka. Tjeritera perkendakan oelar dengan orang.}
E. Kikia hale ilopo
Lehaleha kahai ekitawo,
M. Adalah doeloe di negrie Lehaleha satoe djanda pe- 
E. ke dakoahia kabai kahai eapoe

M. rampoean tetapi malam malam datang satoe oelar

E. kahapoeëi hi ekitawo

M. jang besar hendak berkendak dengan perampoean djanda

E. neëni, noahania dakoahia, daboeodo kamaniaha

M. tahadi bagitoelah tiap tiap malam lama lama maloelah

E. kaäno ekitawo eana, be eapoe

M. kawan (sanak) perampoean djanda itoe sebab oelar

E. kai kahabaeëi hi anona, kaena hakapario

M. datang berkendak dengan sanaknja lantas dia bikin

E. ekonaha iekoa oeapoe eana, dapoelopo

M. perangkap di djalan oelar itoe sasoedah malam

E. kamana kahanea ekaka kamaomo iohki, kabaiha

M. pergi separoh orang mengintai di tepi datanglah

E. eapoe eana kabaikoeaha iho ekonaha eana,

M. oelar itoe masoeklah didalam perangkap itoe

E. kapanihana di boehoka esa oeakaroeba, kapoeoedaha

M. lekaslah di potong ikat pintoenja djatohlah

E. eakao eana, kaeanaha diboehoka ekaraha oeapoe,

M. pintoe itoe lantas dipotong badan oelar

E. kipamimihikaha eënonia idita kabapadi eëa,

M. melompatlompatlah sisiknja disitoe mendjadi batoe

E. kidera kaboedohoida ekitawo eana,

M. semoea didengarlah (oleh) djanda perampoean itoe

E. hobaäo hobeadia, kamanoenoehi ha iabapadi

M. soedah mati sobatnja di mintalah soepaja mendjadi

E. kia eëa, hi earadia kahai kia kihopai kakoemiha

M. dia batoe dan anaknja satoe dia pangkoe mendjadilah

E. eana, kanoaha na eapoe eana hi ekonaha hi

M. itoe bagitoe djoega oelar itoe dan perangkap dan

E. ekaka moö kikia edita kidara kabapadi eëa,

M. orang jang ada disitoe semoea mendjadi batoe

E. kabapadi eahabedoa, noöni afeahai moö

M. lantas mendjadi keramat sekarang barangsiapa jang

E. kapoeho koepo dibaha idita kahabape ekoeè

M. sakit bangkak pergilah di sitoe memberi setan

E. idita, iaoea etapoehodia, noaha edipakoedodo

M. di sitoe soepaja baik sakitnja bagitoe kepertjaän

E. ekaka iteě, eana eadohoda ekoedaäjodia.

M. orang di sini itoelah penghabisan tjeriteranja. Dl. 71 . 
ekitawo $=$ kaboekoe.

dakoahia $=$ karkoahia.

artinja «kipamimihika» seperti orang melempar air maka aie itoe naik kemanamana djadi titik air itoe kena djoega sama kita.

\section{Fkoedaäjo ekaka edikodo moenia. Tjeritera orang di talan ikan kerapoe.}

E. Kikia hale kahai ekaka moö kaäpia iohki

M. Adalah doeloe satoe orang jang berladang di tepi

E. pane i Koma, kaboekoöha epo idita, daboeodo

M. dekat di Koma di tanamlah kelapa di sitoe lama lama

E. kamaämoeho epodia kamahawa, kaboepario kahai

M. besarlah kelapanja berboeah di bikinnja satoe

E. emeno, iho oehapoadia kahai dibaha kia kahabario

M. toewak dalam harinja satoe pergilah dia membikin

E. emenonia, kamoho eoeě eoö koeinana, di boeoëa

M. toeaknja tetapi laoet koewat sekali di bilang

E. noöi : "iaoeiha eöö öö eoeě, keaba oepoehai

M. bagini maskipoen koewat kamoe laoet tiada bisa (kaE. bohki emenoi" iadohada kia kaha-

M. moe) tjaboet (batang) toewak (saja) sesoedah dia bi-

E. bario emenonia di poeaka jona ioebada, kaikạ elopo

M. kin toeaknja poelanglah karoemahnja terang doenia E. kahibaha kia kahabario emenonia eana, M. (pagi harinja) pergi lagi dia membikin toeaknja itoe E. ke iabakoa kia idita, kaboepoaha hobaha M. tetapi sesampai dia di sitoe di lihatnjalah soedah pergi E. ephodia ihoano edioboe enahapinia jo

M. kelapanja di tengah oleh sebab sajangnja kapada E. epho emenonia, kamoeaähko jaha idita, di boedodo M. kelapa toeaknja bernanglah pergi kesitoe dia pegang E. eaaö kahai, ke kapanihana kabai moenia M. pisau satoe tetapi dengan lekas datang ikan kerapoe E. aio, kaboekodoha kia hi eaäodia kia kidodo, M. besar di telannjalah dia dengan pisaunja dia pegang E. kamoho eajo eana kapakokojaäha ekaka edikodoM. adapoen ikan itoe didjalankannjalah orang jang di E. dia eana kapakekehia elopo, kaboeoea noöi M. telannja itoe mengelilingi tanah berkatalah bagini 


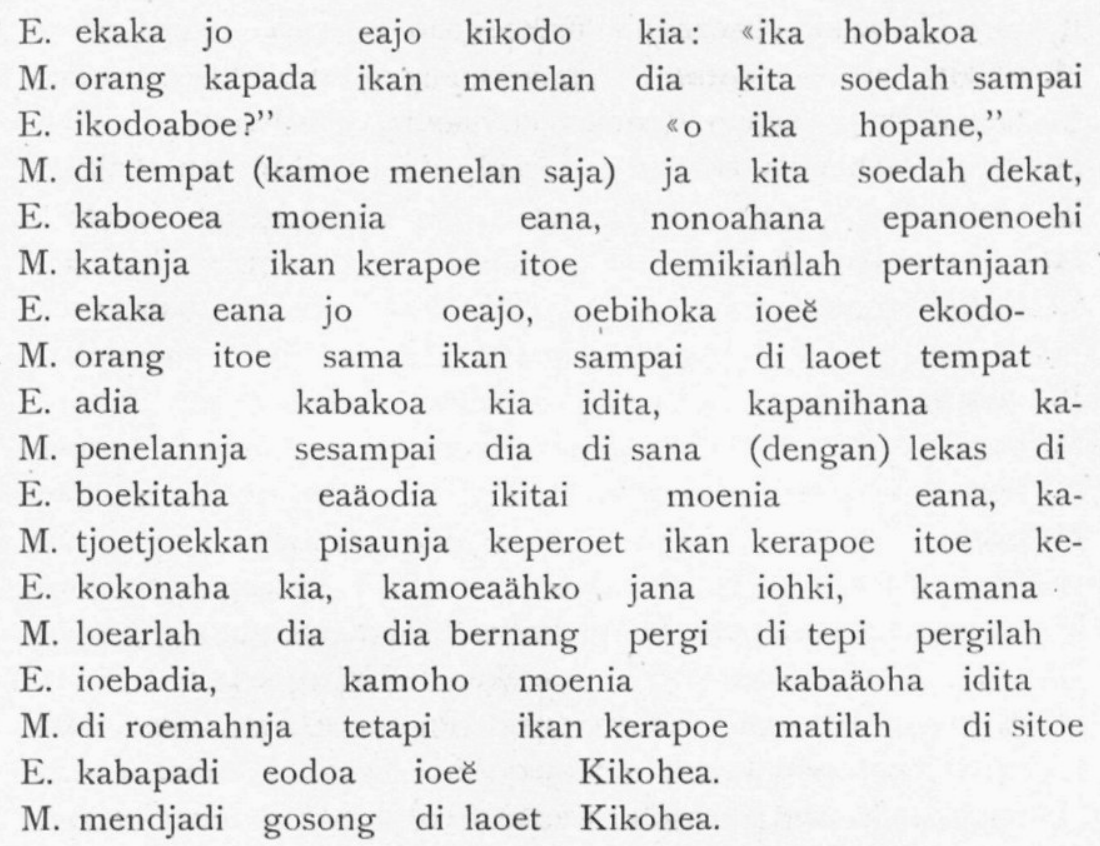

\section{Ekoedaäjo ehöda kahai kanio Badikokaebo.} Tjeritera perampoen satoe bernama Badikokaebo.

E. Kidikoeda kikia hade ilopo eana kahai ekaka

M. Ditjeritrakan adalah doeloe di negrie itoe satoe orang

E. kaha iphiada hi honania, moö kanio

M. pergi keladangnja dengan bininja jang bernama

E. Badikokaebo, kahamoepohoia ehewa ephiada

M. Badikokaebo hendak memboengkoes boewah ladangnja

E. eitto, ke kabakoada kia iphiada, kabahaudiha

M. pisang tetapi sesampailah dia di ladangnja bangkitlah

E. epapoeroe jona, kamoho emani di baha

M. perkalahian sama (dia orang) lantas lelaki pergilah

E. ikoheaädia, ke honania kamaninihai eanehanjonia,

M. di pondoknja tetapi bininja mengerdjakan pekerdjaännja

E. kamoho emani neëni dibibipoi ekoeo pamohomo-

M. maka lalaki tahadi di potong kajoe bermatjam-

E. homa, kapakkoea iho oebo, ke kakepoada

M. matjam di boewang kedalam air tetapi tenggelamlah

E. kidera, kahibiphoe ekoeo kahai, kapakkoea iho

M. samoea di potong lagi kajoe satoe di boewang di 
E. oebo, kaeanaha kaboedoao eana ekoeo eporo, M. dalam air lantas merampoeng itoe kajoe eporo

E. kaparioho ekoeo eana elohaodia, iadohoda

M. di bikinlah kajoe itoe sampannja sesoedah (habis)

E. elohaodia ipario, kamoena eoekoeoedia ekoeo

M. sampannja di bikin di ambilnja galanja kajoe

E. ikaä oebo, kapoeaka, kamoho honania kaboeoea

M. di tepi air berangkat tetapi bininja membilang

E. noöni: "meo oepoeaka iijaha eahoeamoe", ka-

M. bagini mengapa berangkat kemana pergimoe mem-

E. boeoea noöni dadoedia: „iaba idita, oea kahaea

M. bilang bagini lakinja tinggallah di sitoe saja hendak

E. moho, keafe ahai kabaipoe ekoeo

M. pergi lain (tampat) tetapi kalau siapa memotong kajoe

E. idita, abaoea jo earaka, iabakoeda

M. di sitoe bilang sama anak kita soepaja di kasi tahoe

E. jo oea, oepakoeaä ekioe hi ebo kahabapoeroe

M. sama saja saja soeroeh angin dan oedjan memboenoeh

E. kia”, kanoaha oebihoka noöṇi eahaoa kabaipoe

M. dia bagitoelah sahingga sekarang pantang memotong

E. ekoeo iohki koede Eahai, jana ikoeroe Koma,

M. kajoe di tepi dari Eahai sampai di oedjoeng Koma

E. kamoho ekaka dipoeaka jana ikimo.

M. tetapi orang itoe berangkat ke negrie jang tiada

M. ketahoean.

\section{Ekoedaäjo epakodai edahauhoe. Tjeritera permoelaän goentoer (petoes).}

E. Kikia hale ilopo eana ekaka moö kipario

M. Adalah doeloe di negrie anoe orang jang membikin

E. elohao, iadohoda ehabariodia, kabahadiha kaå-

M. sampan soedah habis pekerdjaännja di panggillah te-

E. nonia kahabahaoro elohaodia koede ihokoeë,

M. mannja hendak manarik sampannja dari hoetan.

E. kabakoä kia i Eoeoe, keaba ipoehai boehokai

M. sesampai dia orang di Eoeoe tiada bisa djalan

E. elohao eana, kaenaha kapoeakaha ekaka eana jana

M. sampan itoe lantas berangkatlah orang itoe pergi

E. ioebada, ke ekaka, moö kahaora elohao neëni,

M. karoemahnja tetapi orang jang menarik sampan tahadi 
E. kidopoe iho oelahao kahai epho hi eiia,

M. meninggalkan didalam sampan satoe kelapa dan rotan

E. di poeaka ekaka ioebada, kamoho elohao

M. besar poelanglah orang karoemahnja tetapi sampan

E. neëni kaminaäwa ihea enawaë itebe, ka-

M. tahadi naiklah kedahan boenga kenanga diatas te-

E. boeika elopo, kahaibai ekaka kahaba habaoro

M. ranglah hari datang lagi orang hendak menarik

E. elohaoda, ke hobaha mohu, koeanaha

M. sampannja tetapi soedah pergi lain (tempat) lantas

E. kakao ekitaida kaboepopoa itebe, be elohao

M. heran hatinja melihat keatas sebab sampan

E. kahimamana itebe, iaboedaba, kabapodiha edahauhoe,

M. pergilah keatas lenjap mendjadilah goentoer

E. eana eahhadia abaitji edahauhoe, elohao

M. itoelah sebabnja kalau berboenji goentoer sampan

E. kaboekokoi, kamoho epho ipoko kabahoe-

M. berdjalan tetapi boewah kelapa di dalam bergoeling

E. hoedoe ekaroekoedia moö kioera, noaha eiadia

M. goeling soearanja jang berboenji bagitoelah halnja

E. oebihoka oehapoadia eï kikia elopo eana kanio

M. sahingga pada hari ini ada tanah itoe bernama

E. Kiodahaoelaho, hi eëa moko idita eana,

M. tempat sampan naik dan batoe banjak di sana itoe

E. kidioea, ekaka moö kahaoro elohao eana.

M. kabarnja orang jang menarik sampan itoe.

\section{VERTALING.}

\section{Verhaal van eene rat, die met twee meisjes geslachtelijke gemeenschap had.}

In eene zekere landstreek waren twee beeldschoone meisjes, die niet wilden huwen met de jongelingen uit het land. Aldaar woonde ook een jongeling, die, van wege zijn leelijk uiterlijk, zich schaamde om zich over dag op straat te vertoonen; hij zong echter prachtig. Op een avond begaf hij zich naar de woning van die meisjes, om hun een bezoek te brengen; zij wilden hem echter niet in huis laten. De jongeling hief een gezang aan, waarop de meisjes genegenheid voor hem opvatten en hem lieten binnenkomen. In de woning brandde geen licht. 
Herhaalde malen bezocht de jongeling de meisjes en oefende dan den bijslaap met hen uit. (Aangezien bij zijne komst in de woning nimmer licht brandde) wisten de meisjes, alhoewel hij herhaaldelijk bij hen was geweest, niet, hoe hij er uitzag. Evenmin wist het doesoenvolk dat. Eerst, nadat men hem had begluurd, zag men zijn (leelijk) uiterlijk. Nu de doesoengenooten wisten hoe hij er uit zag, schaamde de jongeling zich zoo, dat hij een vischgraat in zijn achterste stak, in het privaat verdween en toen eene rat werd. Aldus het einde vän den jongeling. Men lachte de meisjes uit. Aangezien zij zich ook schaamden, omdat zij zich met eene rat hadden afgegeven, verlieten zij hun woning en gingen naar het strand, met het doel om (al zwemmende) den overwal (het onbekende land) te bereiken. Een hunner was echter daartoe niet in staat. Verdrietig daarover smeekte $\mathrm{zij}$ om in een steen te worden veranderd. Aldus geschiedde; de steen bevindt zich nog in de Kioabaai. Haar vriendin (bereikte den overwal en) kwam in eene doesoen. Bevreesd door de bevolking te worden gedood, indien zij eene woning binnenging, klom zij in een boom, en bleef op een tak zitten. Eene oude vrouw, die bezig was het erf voor hare woning te vegen, doch het erf maar niet schoon kon krijgen, omdat steeds bladeren van dien boom neervielen, zag, opwaarts kijkende, het meisje zitten en riep haar toe naar beneden te komen. Het meisje werd daarop door de oude vrouw naar hare woning gebracht, en verbleef daar. Ee;st na geruimen tijd kwam de man van de oude vrouw te weten, dat een vreemde zich in hunne woning bevond. Het meisje nu werd uitgehuwelijkt aan een jongeling en baarde zes kinderen. Ten laatste kwam de wensch bij haar man op, om haar en hunne kinderen te verslinden. Toen de vrouw van dit voornemen kennis droeg, wilde zij zich met hare kinderen uit de voeten maken; dit gelukte haar echter niet, met het gevolg, dat zij allen door den man werden verslonden. Niet lang na hun dood herleefden zij weder. Toen de vrouw zag, dat haar man en zijne makkers vertrokken waren, scheepte zij zich met hare kinderen in een kano in en keerde naar haren geboortegrond, bij hare moeder en vriendinnen terug. Aldus luidt het verhaal van iemand, die met een rat geslachtelijke gemeenschap had. 


\section{Verhaal van een kiekendief, die kinderen verslond.}

Eertijds bevond zich nabij Boewoboewo eene doesoen bewoond door landbouwersgezinnen, die, wanneer zij naar den veldarbeid gingen, hunne kinderen in de doesoen achterlieten onder de hoede van eene oude vrouw. Na haren dood hield echter niemand meer toezicht op die kinderen, wanneer men zich naar de "ephija" 1 begaf. Een kiekendief zag dat de kinderen onbewaakt achterbleven en maakte van de gelegenheid gebruik, om een hunner mede te voeren en te verslinden. Aldus ging de kiekendief dagen achtereen te werk, totdat hij bijna alle kinderen had verslonden. Het doesoenvolk was zeer terneergeslagen en bedroefd en overdacht hoe ten deze moest worden gehandeld. Men besloot een kuil te graven, waarin de kinderen zouden worden schuilgehouden met het noodige voedsel, wanneer men aan den veldarbeid ging. Aldus deed de bevolking, toen zij zich weder naar de ,ephija” begaf. De kiekendief zag, dat in de woningen geene kinderen meer aanwezig waren, nam toen eene klappernoot en sloeg daarop, daardoor een geluid gevende, alsof inen doende was om eene noot te splijten. De kinderen, dat geluid hoorende, riepen: "Onze ouders zijn reeds terug." De kiekendief wist nu, waar de kinderen waren, haalde een hunner uit den kuil, voerde het mede en verslond het. Zoo ging de kiekendief steeds te werk, totdat alle kinderen waren verslonden. De doesoenbewoners beraadslaagden nu, hoe zij het moesten aanleggen om den kiekendief te dooden, doch zagen er geen gat in, omdat het dier in een hoogen merbawboom verblijf hield. Eene rat kwam en zeide tot hen: «Wacht maar, ik zal jelui wel helpen; ik zal den kiekendief bedriegen." De rat klom in den boom en sprak tot den kiekendief: "Komaan, laat ik je eens luizen". De kiekendief gaf zijne vleugels aan de rat. In stede van te luizen, knaagde de rat de veeren af en gaf ten slotte den kiekendief een trap, die hem uit den boom deed vallen, waarop hij door het volk werd gedood. Eene zwangere vrouw, die wraak wilde nemen over den dood van haar kind, sneed in den vogel, met het gevolg, dat een der klauwen van den kiekendief met kracht tegen den buik van de vrouw stootte; de buik werd opengereten en de vrouw bleef op de plaats dood. Aldus luidt het verhaal van dien kiekendief.

1 Ephija = bouwland. 
De plek, waar een en ander gebeurde, ligt bij Boewoboewo en heet nu nog: "eanoenoejoe poeroehi» d. w. z.: de plaats, waar de veeren van den kiekendief zijn afgeknaagd.

\section{Verhaal omtrent het ontstaan van aardbevingen.}

In eene zekere landstreek woonde een man, die Kipajoda heette. Hij had een kind, dat echter op jeugdigen leeftijd stierf. Bij het overlijden van zijn kind vaardigde hij (in den rouwtijd) een verbod uit; hij verbood namelijk een ieder, om op zijne bezittingen met een net in zee te visschen. Dat verbod werd echter onophoudelijk door eenige lieden overtreden, omdat zij den lust, om visch te eten, niet konden bedwingen. Zulks wekte immer den toorn van Kipajoda op, die dan ook niet naliet telkenmale tegen hen uit te varen. Het gevolg was dat die lieden ${ }^{1}$ hem een kwaad hart toedroegen, en besloten hem door een list uit den weg te ruimen. Een kuil werd gegraven en zoodanig bedekt, dat zij niet te zien was. Tegen het verbod van Kipajoda in, vischten zij weder met een net in zee en poften den gevangen visch aan den kant van den kuil. Spoedig Rwam ripajoda, ar scnerciende -, aangeloopen, met eene lans in de hand en zette de overtreders na. Aangezien hij uit al zijne macht liep, lette hij niet op waar hij liep, met het gevolg dat hij in den kuil terecht kwam, welke onmiddelijk door zijne vijanden ${ }^{3}$ werd dicht gemaakt. Kipajoda sprak: "Het zij zoo, dat gij aldus met mij gehandeld hebt. Hoor mij aan! Wanneer het (hier) stil en eenzaam blijft, zal dat het bewijs zijn, dat ik gestorven + ben. Mocht ik nog in leven zijn, dan zult gij dat wel gewaar worden." Kipajoda begon daarop (in den grond) te graven en kwam te Poepoekoe uit. Aangezien hij, naar het hem voorkwam, zich nog te dicht bij zijne woning bevond, ging hij voort met graven en kwam te Hoköa uit. Hij meende nu ver genoeg van zijn woonplaats verwijderd te zijn en bouwde zich dáár eene woning. Niet lang daarna deelde Kipajoda het voorgevallene mede aan eene oude vrouw en gaf haar te kennen dat hij een "eahabadoa" ${ }^{5}$ wilde worden. Een ieder, die hem

\footnotetext{
1 Lett.: "makkers".

2 " nklagende".

s " "makkers".

4 " "verdwenen".

${ }^{5}$ Nl.: „dat hij een geest wilde worden; de plek, waar hij bleef, moest dan als heilig worden aangemerkt.
} 
wilde vereeren, moest een offermaal aanbieden, bestaande in gepofte kapajangvruchten, gegisten palmwijn en gepoften djompol ${ }^{1}$. Geofferd mocht echter alleen worden, wanneer Kipajoda (teekenen van leven gaf en) de aarde schudde. Aldus luidt het verhaal omtrent het ontstaan van aardbevingen.

\section{Waarom Kaap Koma (ook wel) Doepaoba wordt genoemd.}

Er waren twee mannen en twee vrouwen, die afgesproken hadden, om elkander bij Kaap Koma te ontmoeten en minnehandel te hebben. De vrouwen gingen pisang stampen, om kiinopha» ${ }^{2}$ te bereiden, welke lekkernij zij alsdan die mannen wilden voorzetten. Twee stukken kiinopha werden klaar gemaakt. Toen de mannen kwamen werd hun een van die stukken voorgezet, dat door hen werd genuttigd. Het andere stuk werd bewaard, om hun den volgenden morgen tot maal te dienen. Bij het aanbreken van den dag vroegen zij aan de vrouwen vergunning om naar huis te gaan en werd hun daarop het tweede stuk kiinopha voorgezet. $\mathrm{Zij}$ openden het pisangblad en bemerkten, dat een kakkerlak van de kiinopha had gegeten, waarop zij op die vrouwen boos werden en weggingen. De vrouwen keerden ook naar hunne woning terug. Kaap Koma wordt daarom dan ook Doepaoba geheeten n.l. de plek, waar minnehandel is gedreven. Het niet genuttigde stuk kiinopha veranderde in steen.

\section{Verhaal omtrent het ontstaan van de zeeschildpad, van de garnaal, van den rog en van den leguaan.}

In de doesoen Dokaijoa wilden vier personen met een groot net in zee visschen. Een hunner zeide tot zijn kameraden: "Ga daarheen om ook voor mij visch te vangen; ik zal, omdat het eb is, hier blijven en al wat ik op het strand vang of vind, dat eetbaar is, verzamelen. Gezamenlijk zullen wij dan een en ander verorberen." Hij verzamelde (inderdaad) de eetbare diertjes en gaf die aan zijn makkers; deze aten ecinter alles op, zonder ook maar een enkele aan hem te geven. Hij werd boos op zijne makkers en zon op wraak. Hij zeide tot een zijner makkers:

1 E. s. v. eetbare zeevisch.

2 Kiinopha wordt bereid van fijn gestampte rijpe pisangs, die, vermengd met de uitgeperste vezels van de klappernoot, gewikkeld worden in een pisangblad en dan gekookt of gepoft worden. 
"Komaan, laat ons een wedloop houden, om te zien, wie van ons het vlugst kan loopen". De makker legde het af. Hij sprak toen tot hem: "Je doet beter een visch te worden, (want) als het eb wordt, zult ge (zeer zeker) worden gedood". Inderdaad werd deze een rog, terwijl hij zelf een garnaal werd. Wat de twee overige makkers betreft, zij wierpen hun net uit en vingen veel visch. Toen de vloed kwam opzetten, verzamelden zij de vangst. Bij het schoonmaken ${ }^{1}$ van den visch kreeg een hunner een schub in het oog. Herhaalde malen dook hij in zee (om zich van de schub te bevrijden); de schub bleef echter in het oog zitten. Hij zeide daarop tot zijn makker: "De schub laat niet meer van mijn oog los; haal ik het oog uit het water, dan doet het mij zeer veel pijn. Ik doe daarom beter in zee te verblijven, opdat mijn oog mij geen zeer meer doet". Zoodra hij die woorden had gesproken, dook hij in zee, (kwam weder te voorschijn), nam een birahblad ${ }^{2}$, bedekte daarmede den rug, dook wederom in zee, waarop hij in eene schildpad veranderde. Toen de overblijvende zag, dat zijne makkers waren verdwenen, wierp hij de vangst weg, nam vervolgens een stuk rottan, die voor het aanrijgen van de visschen moest dienen, stak het in zijn achterste, waarop hij in een leguaan veranderde en in het bosch verdween. Aldus het verhaal.

\section{Verhaal van een slang, die geslachtelijke gemeenschap had met een mensch.}

Eertijds leefde in . de doesoen Leha-Leha eene weduwe, die elken avond een bezoek kreeg van eene groote slang, welke met haar den bijslaap uitoefende. Ten laatste schaamden de verwanten der weduwe zich over haar gedrag en zetten zij zij daarom een val uit om de slang te vangen, ter plaatse, waarlangs zij gewoon was haren weg te nemen. Bij het vallen van den avond gingen zij naar het strand om de komst van de slang af te wachten. Toen de slang in den val kroop, werd snel het touw waarmede de valdeur bevestigd was, doorgesneden; daarna werd de slang in stukken gekapt. De schubben, welke zich allerwege verspreidden, veranderden in steenen. De weduwe, hoorende dat haar vriend gedood was, smeekte om

1 Lett.: ,in tweëen splijten en van de schubben ontdoen”.

2 Birah, een eetbaar knolgewas met breed blad. 
met het kind, dat zij in haar schoot droeg, eveneens in een steen te worden veranderd, hetgeen dan ook geschiedde. Ook de slang, de val en een ieder, die zich bij den val bevond, veranderden in steenen. Allen werden tevens "eahabedoa»'. Al wie nu aan zwelling van het lichaam lijdt en bij de "eahabedoa" offert aan de daarin huizende geesten, zal van de ziekte genezen. Aldus is het vertrouwen van de Engganees (in die geesten) zooals het verhaal meldt.

\section{Verhaal van een moenia ', die een mensch opslokt.}

Eertijds had iemand een tuin aangelegd nabij Kaap Koma, welke tuin met kokospalmen werd beplant. Nadat de palmen vrucht droegen, werd een daarvan bestemd om daaruit "toewak ${ }^{3}$ te verkrijgen. Op een dag, toen de man bezig was om het sap te tappen, was het springvloed. Hij sprak toen tot de zee: "Al zijt ge nog zoo machtig, o! zee!, gij zijt (toch) niet in staat, om den palm, waaruit ik "toewak verkrijg, te ontwortelen". Nadat de man "toewak" had verkregen, keerde hij huiswaarts. Daags daarop ging hij tot hetzelfde doel naar zijn tuin en zag, aldaar aangekomen, dat de kokospalm midden in zee dreef. Aangezien hij met den palm begaan was, zwom hij, een mes met zich voerende, naar de plek, waar de palm dreef. Aldra kwam een groote "moenia» aangezwommen, die hem met het mes, dat hij bij zich had, opslokte en met hem de kust rondzwom. Hij sprak aldus tot de "moenia»: "Zijn wij reeds op de plaats aangekomen, waar ge mij hebt opgeslokt". "Wij zijn er vlak bij, antwoordde de "moenia". Nog enkele malen stelde hij die vraag tot de "moenia», totdat deze hem antwoordde, dat zij op de plaats waren aangekomen. Snel sneed hij met het mes, dat hij bij zich had, den buik van de "moenia" open en kroop uit den buik, zwom daarna naar den wal en keerde naar huis terug. De "moenia", die op de plaats dood bleef, werd bij Kikohéa een "eodoa" ${ }^{4}$.

1 Zie de noot bij rerhaal III.

"De „Jacob Evertsen"?

3 Gegiste, uit den palm getapte, sap.

4 Branding op eene ondiepe plaats of op een rif; hier wordt bedoeld de branding bij de opening tusschen de reven bij Kikohéa. 


\section{Verhaal omtrent de vrouw Badikokaebo.}

Er wordt verhaald, dat eertijds in eene landstreek een man met zijne vrouw, die Badikokaebo heette naar hun tuin ging, om trossen pisang te omwikkelen. ${ }^{1}$ In den tuin aangekomen, kregen zij woorden met elkander, met het gevolg, dat de man naar zijne hut (in den tuin) ging, terwijl de vrouw bij den veldarbeid bleef. De man nu (wilde een kano vervaardigen en) velde verschillende boomen, die hij achtereenvolgens in de rivier wierp, (om te zien of zij dreven); alle boomen zonken. Eindelijk velde hij een eporoboom, die, in het water geworpen, bleef drijven. Hij vervaardigde daaruit een kano. Nadat hij met den arbeid gereed was, nam hij een stok voor duwboom en vertrok. De vrouw sprak (toen zij haar man zag vertrekken) aldus tot hem: "Waarom ga je weg en waar ga je heen?" De man antwoordde: "Blijf waar je ben; ik wil naar elders gaan. Mocht iemand een boom willen vellen, zeg het dan aan onzen zoon, die mij aldra daarvan kennis moet geven. Ik zal dan wind en regen gelasten om dien persoon te dooden." $\mathrm{Op}$ grond daarvan wordt het een ieder verboden om boomen te vellen langs de kust van of Eahai tot Kaap Koma. De man vertrok naar het onbekende land.

\section{Verhaal omtrent het ontstaan van bliksem en donder.}

Eertijds vervaardigde iemand in eene landstreek een kano. Nadat hij met den arbeid gereed was, verzocht hij zijne makkers om hem bij het uitsleepen van de kano behulpzaam te zijn (aan welk verzoek werd gevolg gegeven). Met de kano te Eoeoe gekomen, konden zij die niet verder voorttrekken, waarop zij naar huis gingen, na daarin een kokosnoot en een dik stuk rottan te hebben achtergelaten. Toen zij huiswaarts keerden, steeg de kano tot aan den bovensten tak van een enawaëboom. Den volgenden morgen teruggekeerd om de kano verder te sleepen, zagen zij die niet meer. Opwaarts kijkende zagen zij, tot hunne verbazing, dat zij opsteeg, (ten slotte) in het luchtruim verdween en in den bliksem veranderde. Onweert het nu, dan beweegt de kano zich voort; de kokosnoot, die zich telkenmale tegen de wanden van de kano

1 Inz. om de vogels van de rijpe pisangs af te houden. 
stoot, brengt het rommelend geluid van den donder teweeg. Tot den huidigen dag toe wordt die plaats genoemd «kiodoha oelahao», de plaats, waar de kano opsteeg. En de personen, die de kano hebben uitgesleept, zijn allen, aldus luidt het verhaal, in de steenen veranderd, die bij die plaats liggen.

\section{Verhaal van een vloedgolf, die in vroegeren tijd Enggano verwoestte.}

Op zekeren dag, aldus het verhaal, bereikte de vloed zulk eene ongekende hoogte, dat het eiland door de zee werd overstroomd en ieder levend wezen verdronk op één vrouw na. Hare redding dankte zij aan het zoodanig verward raken van haar haar in een doornachtigen boom, dat zij door den stroom niet kon worden medegevoerd en zich aan dien boom kon vastklampen. Bovendien zwom zij uitstekend. Nadat het water weder tot het normale peil was gedaald, klom zij den boom af. $\mathrm{Zij}$ was erg bedroefd toen zij zag dat zij alleen op de wereld stond, en wandelde, om afleiding te zoeken, heen en weer langs het strand. Aangezien zij honger begon te krijgen, liep zij landwaarts in om voedsel te zoeken, doch vond niets, waarmede zij zich zoude kunnen voeden. Mistroostig keerde zij naar het strand terug, in de hoop een visch te kunnen vangen om haar honger te stillen. Wel zag zij een visch, doch, toen zij den visch wilde vangen, drong die in het lichaam van een der omgekomenen. Snel nam zij een steen op en klopte daarmede met kracht op het lijk, ter plaatse, waar de visch was binnengedrongen. De visch sprong het lijk uit en verdween landwaarts. $\mathrm{Z}_{\mathrm{ij}}$ wilde den visch nazetten, doch nauwelijks had zij eenige stappen gedaan of zij ontmoette een manspersoon. $\mathrm{Z}_{\mathrm{ij}}$ schrok geweldig. $\mathrm{Na}$ van den schrik te zijn bekomen, vroeg zij hem, waar hij zoo plotseling van daan kwam; op háár na was toch een ieder bij den vloedgolf verdronken. Hij zeide haar, dat men op zijn lijk had geklopt, waarop hij tot het leven was teruggekeerd. De vrouw vertelde haar wedervaren aan den man. $\mathrm{Z}_{\mathrm{ij}}$ besloten nu ook op de andere lijken met een steen te kloppen, in de hoop dat die dooden tot het leven zouden wederkeeren. Zoo gezegd zoo gedaan. En zie! De dooden herleefden. $\mathrm{Zij}$ (de man en de vrouw) lieten hen bijeenkomen met het doel om hen in drie gelijke partijen (opahiejaka) te verdeelen, waaraan zij de namen "Kaädoebie», "Kahaäka» en 
«Kaähoa» wilden geven. Na de verdeeling bevonden zij, dat "Kahaäka» en "Kaähoa» gelijk in aantal waren, "Kaädoebie» daarentegen sterker in aantal was dan «Kaähoa» en "Kahaäka». $\mathrm{Z}_{\mathrm{ij}}$ zonderden toen het meerdere aantal van «Kaädoebie» af, namen een blad van eoaieboom en sloegen daarmede elk dier personen op den rug, met het gevolg dat zij dood neervielen. De opahiejaka's (soekoe's) ' ${ }^{1}$ huwden onder elkander en bevolkten gaandeweg wederom Enggano. Aldus luidt het verhaal omtrent den oorsprong van de Engganeesche bevolking.

\section{Hoe de Engganees aan vuur kwam.}

Oudtijds leefde een man, die een aanzienlijke lengte had. Op zekeren dag stond hij met den rechtervoet op het eiland «Kèpoe adoewa» en met den linkervoet op het eiland "Kèpoe K(a)oeqpanoe», terwijl hij het gelaat naar het noorden had gekeerd. Hij hield in de hand een lang en dik stuk hout van den èooeboom, dat uitgebrand was. Met kracht slingerde hij het stuk hout naar het eiland "Kèpoe Kaikoekka» ${ }^{2}$, waar het aan den voet van den berg Nanoeoea terecht kwam. Zoodra het stuk hout op den grond viel, vatte het vlam. Toen de bevolking dat zag, liep zij den berg af om het stuk hout weg te halen, doch slaagde daarin niet omdat een rat het vuur had uitgedoofd, nadat zij een gloeienden sintel had medegenomen. De bevolking zette de rat na; deze wist aan hare vervolgers te ontkomen, door in eene opening van een grooten boom te kruipen. Ten tweede male slingerde de man een uitgebrand stuk hout, nu van den èpoeninoboom, naar het eiland «Kèpoe Kaikoekka». Het stuk hout kwam wederom terecht aan den voet van den berg Nanoeoea, nabij de plaats waar het eestbedoelde stuk hout was neergekomen. Ook nu vatte het vlam, zoodra het op den grond viel. Opnieuw trachtte de bevolking het vuur machtig te worden, doch wederom zonder resultaat, omdat ook nu de rat het vuur had uitgedoofd, nadat zij een gloeienden sintel had medegenomen. De bevolking in hevigen toorn ontstoken, makkte jacht op de rat, die ten slotte gevangen

1 Een andere lezing omtrent den oorsprong der bevolking en het ontstaan der soekoes, geeft het verhaal medegedeeld in mijne bijdrage ,de Eilandengroep Enggano" (Tijdschrift v/h Ned. Aardr. Genootschap, meer uitgebreide artikelen Jaargang 1888, pag. 285 en 286).

2 Het hoofdeiland van de "eilandengroep Enggano". 
werd. Toen de bevolking de rat wilde dooden, vroeg zij om vergiffenis en beloofde zij haar aan het vuur te helpen. De rat, die vergiffenis kreeg, gaf daarop de sintels, welke nog niet waren uitgedoofd, aan de bevolking.

\section{Hoe de Engganees aan zijn eersten ,èko(q)hajo" (geneeskundige) kwam.}

In eene doesoen, niet meer bij name bekend, leefde een man met zijne vrouw en dochter. Toen het meisje den huwbaren leeftijd had bereikt, kwam een geest, in de gedaante van een schoonen jongeling, bij haar en vroeg haar om hare hand. Aangezien de jongeling bovendien een mooie stem had, bekoorde hij weldra het meisje, zóó, dat zij op zijn aanzoek inging. De geest leefde met haar als man en vrouw. Op een dag bemerkten de ouders, dat hunne dochter in gezegende omstandigheden verkeerde en vroegen haar, wie haar wel zwanger had gemaakt. Het meisje zeide: "Ouders, zijt niet boos op mij; een geest is mijn echtgenoot. Hij is voor een ieder, uitgenomen voor mij, onzichtbaar. Ik kan alleen zijne stem hooren". Op een dag zeide de geest tot het meisje: "Ik moet voor een vijftal dagen naar het geestenrijk terugkeeren, om mijne bloedverwanten op te zoeken. Op een plaats aan het strand, die ik je bij mijn vertrek zal aanwijzen, moet je eenige trossen rijpe pisang neerleggen, die mij als leeftocht op mijne reis moeten dienen. Zeg dit aan je ouders". Het meisje deelde, wat de geest haar verzocht had, aan hare ouders mede. Op den dag van het vertrek begaf het meisje zich, door hare ouders en verwanten vergezeld, naar het strand. De trossen rijpe pisang werden neergelegd op de door den geest aangewezen plaats. Voor zijn vertrek sprak de geest tot het meisje: "Ik ga nu weg, wacht over vijf dagen hier mijne komst af'. En de geest verdween, de trossen pisang met zich medevoerende. Toen de vijfde dag dáár was, ging het meisje, wederom door hare ouders en verwanten vergezeld, naar de plaats aan het strand, waar de geest haar verwachtte. Aldaar aangekomen, vonden-zij eene groote hoeveelheid bij elkander gebonden visch op het strand liggen. De geest sprak nu tot het meisje: «Zeg aan je ouders, dat de visch, die hier ligt, van mij is en als tegengeschenk moet dienen voor al hetgeen ik van hen heb ontvangen. Kom, laten wij nu naar huis gaan". Allen keerden terug. Niet lang 
daarna bracht het meisje een blinden zoon ter wereld. De geest zeide tot haar: "Thans is de tijd voor mij aangebroken om je voor altijd te verlaten. Wij hebben nu een kind. Zorg goed voor het kind. Ge zijt nu vrij en kunt huwen, wien ge wilt". Het meisje antwoordde bedroefd: "Indien aldus uw besluit is, zal ik mij aan uwen wil onderwerpen". De geest verliet haar en kwam niet meer terug. Nadat het kind den mannelijken leeftijd had bereikt, gebeurde het, dat de bevolking door eene hevige epidemie werd geteisterd, die velen ten grave sleepte. Aan een ingezetene werd in een droom geopenbaard, dat de blinde jongeling de ziekte kon genezen. Hij werd ontboden, betastte het lichaam der lijders, die in een oogwenk herstelden. Sedert dien verleende hij steeds hulp aan zieken en werd de geneeskundige van de doesoen. De jongeling was inmiddels gehuwd en werd vader van een zoon, die door hem tot geneeskundige werd opgeleid. Uit zijn geslacht nu zijn de geneeskundigen op het eiland Enggano voortgesproten. Aldus het verhaal.

\section{Verhaal omtrent het ontstaan van den krokodil.}

In de doesoen Barohia leefde een stokoude leproos, die toezicht moest houden op alle kleine kinderen in die doesoen, wanneer hunne ouders aan 'den veldarbeid gingen. Op een dag, toen de ouders weder afwezig waren, zeide hij tot de kinderen: "Ik moet naar de rivier, om te baden, jelui moet met mij medegaan". De kinderen waren zeer in hun schik, dat zij met hem mochten gaan baden. Bij de rivier gekomen, liet hij de donkergekleurde kinderen op een heuvel wachten en ging met de lichtgekleurde kinderen een bad nemen. Nadat zij gebaad hadden verslond hij hen, het eene na het andere. Daarop keerde hij naar de doesoen terug op den voet gevolgd door eerstgenoemde kinderen. Toen de ouders, bij hunne terugkomst, niet alle kinderen terugzagen, vroegen zij aan den ouden man, waar de overigen waren gebleven. Hij antwoordde hen, dat zij hem, zonder zijne voorkennis, hadden verlaten, toen hij aan het baden was, en dat hij te vergeefs naar hen had gezocht. Dat vernemende, doorkruisten de ouders het eiland in verschillende richtingen om hunne kinderen op te sporen, echter zonder eenig resultaat; zeer bedroefd keerden zij naar de doesoen terug. Op zekeren dag, terwijl de oude man bezig was in een privaat boven de rivier zijne behoefte te doen, hoorde één 
hunner een plomp in het water, alsof een kokosnoot daarin viel. Hij liep naar het privaat en zag dat de ontlasting van den ouden man uitsluitend uit kinderhoofden en beenderen bestond. Hij vertelde onmiddelijk aan zijne doesoengenooten, wat hij gezien had en zeide tot hen: "Niemand anders dan de oude man heeft onze kinderen verslonden. Wij moeten er wat op vinden om hem te dooden, want anders verslindt hij ook de kinderen, die ons nog overblijven." Al beraadslagende, kwam men ten slotte overeen, dat, wanneer zij weder aan den veldarbeid gingen, enkelen hunner zich zouden schuilhouden nabij de badplaats in de rivier, om den ouden man te bespieden. Daags na de beraadslaging zeiden zij tot den ouden man: "Vader, wij gaan aan den veldarbeid, breng onze kinderen naar de rivier om hen te baden." "'T is goed" antwoordde de oude man. Inmiddels hadden degenen, die bij de badplaats zouden achterblijven om den ouden man te bespieden, uit bamboe lange en zeer puntige lansen gesneden. Toen de oude man, nadat hij de kinderen had gebaad, één hunner wilde verslinden, kwamen zij met hunne bamboezen lansen uit hun schuilhoek te voorschijn. De oude man dit ziende, dook in het water. Snel werden hem de lansen nageworpen, met het gevolg, dat één daarvan in 's mans achterste bleef steken en onmiddelijk in een staart veranderde van vijf vademen lengte. De oude man kwam kort daarop als een krokodil uit het water te voorschijn en sprak hen toe: "Je hebt mij willen dooden en dat is jelui niet gelukt. Je ziet, dat ik nu een krokodil ben geworden. Uit wraak dat je mij hebt willen dooden, zal ik steeds jelui's vijand blijven." Daarna verdween de krokodil. Dit nu is het verhaal omtrent het ontstaan van den krokodil op het eiland Enggano.

\section{Verhaal omtrent een mensch, die, na in een varken te zijn veranderd, weder een mensch werd.}

Eertijds leefde in de doesoen Padoja een huisgezin bestaande uit man, vrouw, één zoon en ééne dochter. Op zekeren dag ging de moeder met hare kinderen naar de rivier, ieder een waterkoker medenemende. Bij de rivier gekomen sprak de moeder tot hare kinderen: "blijf hier, ik ga even het bosch in, om wat bladeren te halen." Nadat de kinderen een geruimen tijd op de terugkomst van hunne moeder hadden gewacht en deze maar niet terugkeerde, gingen zij het bosch in om naar hunne Dl. 71 . 
moeder te zoeken. Zij vonden haar terug, bezig zijnde een nest te maken, dat op een varkensnest (leger) geleek. De kinderen riepen: "Moeder, wat doet ge dáár en wat voert ge dáár uit." Zij gaf geen antwoord doch begon te knorren als een varken. "Moeder, waarom knort ge als een varken" riepen de kinderen daarop. De moeder antwoordde: "Keer dadelijk naar huis terug en zeg aan vader, dat ik een varken ben geworden. Indien vader mij wil vangen, dan moet hij dat persoonlijk doen met een werpnet, anders kan men mij niet in handen krijgen." De kinderen gingen naar huis terug en vertelden aan hun vader, wat voorgevallen was. Deze nu ging met spoed een groot net vervaardigen uit den bast van den bagoeboom. Toen het net gereed was, ging hij met zijne kinderen het bosch in om het varken te vangen. Nauwelijks zag de man het varken of hij wierp het net uit en had het geluk het dier te vangen. Het varken werd naar huis gebracht en aldaar geslacht. De man sneed daaruit een achterbout, gaf dien aan de kinderen en sprak tot hen: "Kinderen, hier is een achterbout en bewaar dien zorgvuldig op de horde, waarop wij onzen visch rooken." $\mathrm{Z}_{\mathrm{ij}}$ voldeden aan het verlangen van hun vader. En zie! Kort daarop kwam hunne moeder uit den achterbout te voorschijn. Toen de vader dit ook zag, nam hij een lang en dik stuk bagoetouw om zijne vrouw te binden. Deze zeide nu: "Man wat hebt ge met mij voor; ge behoeft mij niet te binden. Ik ben wederom een mensch geworden en verlaat je niet meer." Het gezin leefde daarna nog geruimen tijd genoegelijk en in vrede met elkander. Aldus het verhaal.

\section{Verhaal omtrent een mensch, die met eene slang bevriend was.}

Oudtijds woonde in de doesoen Léha-Léha een man, Oefo genaamd, met twee makkers; de eene heette Parikloha, de andere Karakiwah. Op zekeren dag ging Oefo alleen het bosch in. Hij werd overvallen door een storm, vergezeld van slagregen, en zocht naar een plek, waar hij kon schuilen. Hij vond nergens zoo'n schuilplaats, doch trof een djawiboom van grooten omvang aan, waaronder hij zich tegen wind en regen trachtte te beschutten. Kort daarop kwam uit den boom eene slang te voorschijn, die niet minder dan tien vademen lang was en een omvang had van zijne lengte. Oefo ontstelde hevig. De slang 
sprak tot Oefo: "Wat komt ge hier doen?" Oefo antwoordde: "Ik ben hier gekomen, om voor den hevigen storm en den regen te schuilen". De slang zeide: "Dan vind ik het goed, dat ge hier blijft; ge moet nu dan ook maar met mij vriendschap sluiten. Wilt ge echter geen vriendschap met mij sluiten, dan moet ik je verslinden". Oefo antwoordde: "Hoe moet ik het aanleggen om met je vriendschap te sluiten". De slang zeide: "Nu dat is eenvoudig genoeg; breng mij dagelijks maar een kikvorsch tot voedsel, ik word dan je vriend". "Dat is goed", sprak Oefo. Oefo bracht een kikvorsch bij de slang, die nu zijn vriend werd en wel in die mate, dat hij het dier ten slotte bij zich in huis nam. De slang week geen oogenblik van zijne zijde. Op zekeren dag vernam Oefo, dat in de bergdoesoen Pahanoma een weduwe woonde, die er buitengewoon goed uitzag. Bij Oefo kwam aldra het verlangen op, om met die weduwe liefdesbetrekkingen aan te knoopen. Op zekeren avond ging hij, tot dat doel, met zijn makkers Parikloha en Karakiwah naar die doesoen; de slang vergezelde hen. $\mathrm{Zij}$ makkten den tocht te water, terwijl de slang het boschpad volgde. Aangekomen bij den voet van den berg, verliet Oefo de kano, om, door de slang vergezeld, den berg te beklimmen. Parikloha en Karakiwah bleven achter ter bewaking van de kano. In de doesoen ontmoette Oefo de weduwe en noodigde deze hem uit hare woning binnen te gaan. De slang, die niet door de weduwe was opgemerkt, bleef onder het huis op Oefo wachten. In den nacht verliet Oefo de weduwe en keerde met zijn vriend, de slang, zoomede met zijne makkers Parikloha en Karakiwah naar Léha-Léha terug. Dagen achtereen werden de tochten tot bezoek van de weduwe, zooals beschreven werd, herhaald. Op zekeren avond nam de weduwe voor hare woning afscheid van Oefo en zag zij de slang van onder hare woning te voorschijn komen en Oefo achterop gaan. $\mathrm{Z}_{\mathrm{ij}}$ schrikte geweldig, toen $\mathrm{zij}$ de slang zag, te meer nog, omdat het dier buitengewoon lang en groot van omvang was. De slang was zóó lang, dat haar staart nog in de doesoen was te zien, toen Oefo reeds den voet van den berg had bereskt. In hare ontsteltenis riep zij hare bloedverwanten en de andere ingezetenen van de doesoen bij elkander en zeide hen: "Weet jelui het niet. Elken avond komt in onze doesoen een slang, die iemand, die mij een bezoek brengt, achteropgaat. Zij is zóó lang, dat ik haar staart nog zag, toen die man 
reeds den voet van den berg had bereikt. Ik zag de slang van onder mijne woning te voorschijn komen, toen ik voor mijne woning van dien man afscheid nam." Aangezien men niet aanstonds geloof wilde hechten aan het verhaal van de weduwe, sprak men af om den volgenden avond op den loer te liggen en de komst van Oefo af te wachten. Oefo kwam in de doesoen, naar gewoonte door de slang vergezeld. Hij ging de woning van de weduwe binnen, terwijl de slang onder het huis verbleef. De doesoengenooten besloten nu beide om het leven te brengen, zoodra Oefo de woning van de weduwe zoude verlaten om naar zijne woonplaats terug te keeren. Al schuilhoudende, wachtte men dat tijdstip af. Nauwelijks kwam Oefo de woning uit of hij werd dood geslagen, terwijl men de slang den kop afhakte, waarop beide in een steen veranderden. Het bloed, dat uitvloeide, vormde een beekje, dat in zee uitmondde. Zoodra Parikloha en Karakiwah dat beekje zagen stroomen, waardoor de schubben van de slang werden medegevoerd, begrepen zij aldra, dat Oefo en de slang waren gedood. $\mathrm{Zij}$ begaven zich onmiddelijk naar de doesoen en vroegen aan de bevolking waar Oefo en de slang waren. De bevolking antwoordde: "Wij hebben beide gedood omdat wij voor de slang bevreesd waren." Parikloha en Karakiwah keerden bedroefd naar Leha-Leha terug en gaven van het gebeurde kennis zoowel aan Oefo's verwanten als aan de andere doesoengenooten. Besloten werd om bloedige wraak te nemen. Toen het volk van Pahanoma de bewoners van Léha-Léha in grooten getale en in volle wapenrusting in de verte zagen aankomen, rustten zij zich ook ten strijde uit. Het invloedrijkste hoofd, tevens de oudste in jaren, van de doesoen Pahanoma sprak nu: "Wij kunnen ons niet tegen het volk van Léha-Léha verdedigen, zij zijn te sterk in aantal. En zeker zullen wij het onderspit delven. Vel onmiddelijk den langsten en zwaarsten boom, die in het bosch te vinden is en breng dien hier." Al spoedig werd zoo'n boom geveld en naar de doesoen gesleept. Nauwelijks had het volk van LehaLeha halverwege den berg beklommen of de boom werd met alle kracht de helling afgerold, met het gevolg dat de vijand verpletterd werd. Toen de Pahanomanezen zagen, dat hunne vijanden gesneuveld waren, was er groote vreugde in de doesoen. Men juichte en vierde feest. Op raad van gęnoemd hoofd werd toen besloten de doesoen Léha-Léha te overrompelen, want 
zeide hij: "Nu in den strijd zoovele Léha-Léhanezen zijn gesneuveld, zal het aantal weerbare mannen nog slechts gering in aantal zijn. Het zal ons dus weinig moeite kosten hen te vernietigen". Men trok in grooten getale naar Léha-Léha op en posteerde zich op de hoogte nabij die doesoen. Toen de LéhaLéhanezen hen gewaar werden, gingen zij hen te gemoet, slaagden er in hen te omsingelen en te dooden. Slechts meergenoemd hoofd wist zich door de vlucht te redden. In de doesoen teruggekeerd, terneergeslagen en bedroefd, sprak hij: "Onze makkers zijn gesneuveld. Het volk van Léha-Léha zal zich weder opmaken om onze doesoen aan te vallen. Wij hebben nu nog minder strijders dan vroeger om tegenweer te bieden. Wij moeten nu trachten hen door een list te dooden." "Wat moeten wij dan doen?" vroeg het volk. Toen zeide hij: "Graaf nu zoo spoedig mogelijk zeven kuilen, elk ter lengte van twee vademen, ter breedte van twee vademen en ter diepte van vijf vademen en bedek die met dunne planken, welke zoo fijn mogelijk met den dissel moeten worden bewerkt, zoodat ze tot zitplaats kunnen dienen." Nadat het werk gereed was, zond hij eenige afgezanten naar de Léha-Léhanezen, om hun voor te stellen te Pahanoma vrede te sluiten, aangezien bij den oorlog reeds zoovele strijders waren gevallen. De Léha-Léhanezen namen het voorstel aan en verzochten aan de afgezanten om zulks aan het volk van Pahanoma mede te deelen. Te Pahanoma werd nu alles in gereedheid gebracht om de Léha-Léhanezen feestelijk in te halen en te ontvangen. Wapens en manden werden verzameld om als geschenk te worden aangeboden, terwijl van pisang, keladi ${ }^{1}$ en birah verschillende lekkernijen werden klaargemaakt. Toen het volk van Léha-Léha in optocht kwam aanzetten, werd het, onder gejuich, feestelijk ingehaald. In de doesoen gekomen, noodigde men hen uit zich neder te zetten op de, zooals men zeide, voor deze gelegenheid in gereedheid gebrachte zitplaatsen. De Léha-Léhanezen, geen kwaad vermoedende, gingen zitten. Nauwelijks hadden zij plaats genomen, of de planken braken, met het gevolg dat alle Léha-Léhanezen in de kuilen vielen en den dood vonden. Groote vreugde heerschte weder in de doesoen Pahanoma. Men juichte het hoofd toe, omdat hij de doesoen had gered en het volk van Léha-Léha had vernietigd. Aldus

1 E, s, v. eetbaar knolgewas. 
luidt het verhaal van een Léha-Léhanees, die met eene slang bevriend was en de oorzaak werd van de ramp, welke het volk van Léha-Léha getroffen heeft.

\section{E. MINNELIEDEREN (Èhèboe).}

\begin{tabular}{|c|c|c|c|}
\hline $\begin{array}{l}\text { Apèloie } \\
\text { heb lief } \\
\text { abiebie(j)a } \\
\text { riend(in) }\end{array}$ & $\begin{array}{l}\text { baäoe(w)a } \\
\text { ik } \\
\text { biebie(j)a } \\
\text { vriend(in) }\end{array}$ & $\begin{array}{l}\text { kieèdoie } \\
\text { ween van vreugde } \\
\text { maämoho. } \\
\text { zonder wedergade. }\end{array}$ & $\begin{array}{l}\text { noe(w)aäwa } \\
\text { zeer vereerde }\end{array}$ \\
\hline
\end{tabular}

Ik heb $u$ lief en ween van vreugde (als ik u zie, zeer vereerde vriend(in). (Gij zijt) een vriend (in) zonder wedergade.

Is de jongeling (het meisje) haar (hem) genegen, dan wordt geantwoord:

Apawokie baäoe(w)a kieohokie napoeoë(j)a

bemin $\mathrm{u}$ ik stort tranen van vreugde vriend(in) kanaou(w)a biebie(j)a maämoho. bloedverwant(e) vriend(in) zonder wedergade.

Ik bemin u en stort van vreugde tranen (nu gij mij genegen zijt), mijn vriend(in) mijn bloedverwant(e). (Gij zijt) een vriend(in) zonder wedergade.

Is de jongeling (het meisje) haar (hem) niet genegen, dan wordt geantwoord:

Obapalie baäoe(w)a bakaäha nanèkè(j)a oeoëpè gelijk ik birah birah niet houd (van) iediepoedoe kèhèbo(w)a oeboepè baäoe(w)a ie(j)odojah helder weer houd (van) ik goed in bladwaniepoah. zittend schaduwrijke boom.

(Ik houd niet van u) gelijk ik niet van birah houd; ik houd van helder weer, van een boom, die goed in blad zit en schaduwrijk is.

Minnelied opgedragen aan een gehuwde vrouw.

Afèloie baäoe(w)ě daiebie(j)ě koedodoka kienieaiema houd ik vriendin lichaam man oewahieě ahjo boeědokie baoe(w)ě ofajada koedodoka N.N. vroeger neem ik soekoe lichaam afèloie maknafo. houd voor niet. 
Ik houd van u (ik mag u lijden) vriendin, gaarne zoude ik u de mijne noemen, het kan nu evenwel niet, omdat gij reeds getrouwd zijt.

Minnelied opgedragen aan eene weduwe of gescheiden vrouw. Adabaoe $(w) \check{~ k o f a w o k i e ~ b a o e(w) e ~ k a b a h a j e ̀ ~ w e ̀ n o w a ~}$ hoe nu ik wensch ik mooi lichaam (posdaiebie(j)ऍ aboeaboe oaäo kamahanie bodie(j)と tuur) vriendin hoe nu hoe nu duur koopen dokakie(j)と kapfoene.

geen goederen geen kapmes.

$\mathrm{Ik}$ zoude $\mathrm{u}$ tot mijne vrouw begeeren vriendin, want gij zijt schoon; ongelukkig genoeg bezit ik noch goederen noch kapmessen om $\mathrm{u}$ te koopen.

Laatstgenoemde liederen werden reeds medegedeeld in mijne hiervoren geciteerde bijdrage "de eilandengroep Enggano».

De Èhèboe wordt in lang gerekten toon geneuried aldus:

Apèlo apèloööööie baäoe baääeoeoe(w)a kieèdo kièdoie èèèdoie noe(w)aäwa noe(w)aääääwa wabiebie(j)a biebiebie(j)a biebie(j)a biebiebiebie(j)a maämoho maääämoho. 


\section{VERBETERINGEN.}

Pag. 473 11 regel van boven te doen vervallen het woord "dan".

" 477 staat: „bahabaieba"; moet zijn: „babahaieba [babahaiebĕ; pamahaieba].

„ 482 staat: „èhèla; I vol, gevuld; kèohèla ...."; moet zijn : „èhèla, I vol, gevuld (?); kèohèla ...." II. vleesch.

" 483 staat: "èhopo"; moet zijn: „èhopa".

" 485 staat sub „èkaha": „sehorpioen"; moet zijn : „schorpioen".

" 485 staat sub ,èkapèlo": „papegaaisoort”; moet zijn: „papajasoort”.

" 487 staat: èkiemo; I schelp"; moet zijn: „kiemo; schelp”. II en het vraagteeken te doen vervallen.

" 488 staat: „èkoropie ....."; moet zijn: „èkoropie [èkorofie; koropie; korofie], merg; èkoropie(ie)oedoe [ie(oe)loe], hersenen.

" 488 staat: „èmoőie(j)a [ẻmoõie(j)ĕ]"; moet zijn : „èmoö(ie)ja [èmoö(ie)jě]”.

" 489 staat: „ènèanèa"; moet zijn: „ènè(a)nèa".

" 492 staat sub „èpiepie": „èfiefie"; moet zijn: „èpiefie".

" 492 staat sub „èpiedjoeapo": „eěne"; moet zijn: „eene".

" 492 staat sub „èpieko": „manggistam"; moet zijn: „manggistan”.

" 496 staat: „kaäkienafah”; moet zijn: „kaäkieniepa(h) [kaäkieniefa(h)]”.

" 496 staat: „kabèhoq"; moet zijn: „kabèho(q)".

" 497 staat: „kahao"; moet zijn: „kahao(e)".

" 498 staat sub „kakarie(j)o": „10 hooge"; moet zijn: „10 voet hooge". 


\section{A A N V ULLINGEN.}

Pag. 475 bij te voegen tusschen „ajoqoie" en „akieäkiena": „akènaie [ook: àkèlaie]; kiezen, uitkiezen, een keuze doen uit".

" 476 bij te voegen sub „akiedaq": „[ook: akiekiedaq]".

" 480 bij te voegen sub „èbaka": „èbaka: èpie(j)a [èfie(j)ě], zaad".

" 481 bij te voegen sub „èdieja": „[ènieja]”.

" 482 bij te voegen tusschen „èèodie" en „èèoq": "è(è)oewè; zee".

" 485 bij te voegen sub ,(è)kahaèq": „eenig, alleen".

". 485 bij te voegen sub „èkanoeoenoe" ashter "vogelklauw": "nagel".

" 489 bij te voegen tusschen „èodöda" en "èodoe": „èododöoeie(j)o; roer van een schip".

" 491 bij te voegen sub ,èononie": „ook een groote mand van rottan".

" 491 bij te voegen tusschen "èopoe" en "èoqoe": „èopoeĕ [èofoeè]; sperma".

" 491 bij te voegen sub „èpahoe(wa)": „[èpahoe(w)ĕ]".

" 493 bij te voegen tusschen „èpoökie" en „èpoqa": „èpoöpo [èfoöfo], kapel, vlinder".

" 494 bij te voegen tusschen „hèie'j)o" en "hie": „hè̀(j)amakaoe(w)aq; zin, beteekenis".

" 494 bij te voegen tusschen „iedjie" en „ieho": „iedjiedja(h) [ook: èpaie$\operatorname{dja}(\mathrm{h})]$; daarheen, daarginds.

" 495 bij te voegen tusschen "kaädodie" en "kaädoja": "kaädoewè; kaädoewè èiedjie [è̀jjie], niet van willen weten, verloochenen".

” 496 bij te voegen achter "kadèdè": „[kalèlè]".

" 497 bij te voegen sub „kahienoa(q)": „vgl. èkahieno(a)".

" 498 bij te voegen tusschen „kakanaka" en „kakanakoe(w)a": „kakanè(ie)q; kakanè(ie)q(è)baka, blind".

n 498 bij te voegen achter "kakèkaka": [ook: kakĕkaka].

" 498 bij te voegen tusschen „kakiedohè" en ,kakiekiedohè": „kakieho; verbrand, weggebrand".

" 498 bij te voegen tusschen "kakieho" en „kakiekiedehè": „kakieie; snijden van rottan en bamboe". 